$\frac{74}{10-14.80} 9+6$

Prepared for:

U.S. Department of Energy

Economic Regulatory Administration

Office of Utilities Systems

Emergency Electric Power Administration

Prepared by:

John R. Labadie

Seattle, Washington 98118

Under Contract No. AT01-80RG10327

\section{Dr. 1839}

DOE/RG/10327-01

Dist. Categorie UC97

\title{
ELECTRIC POWER EMERGENCY HANDBOOK
}
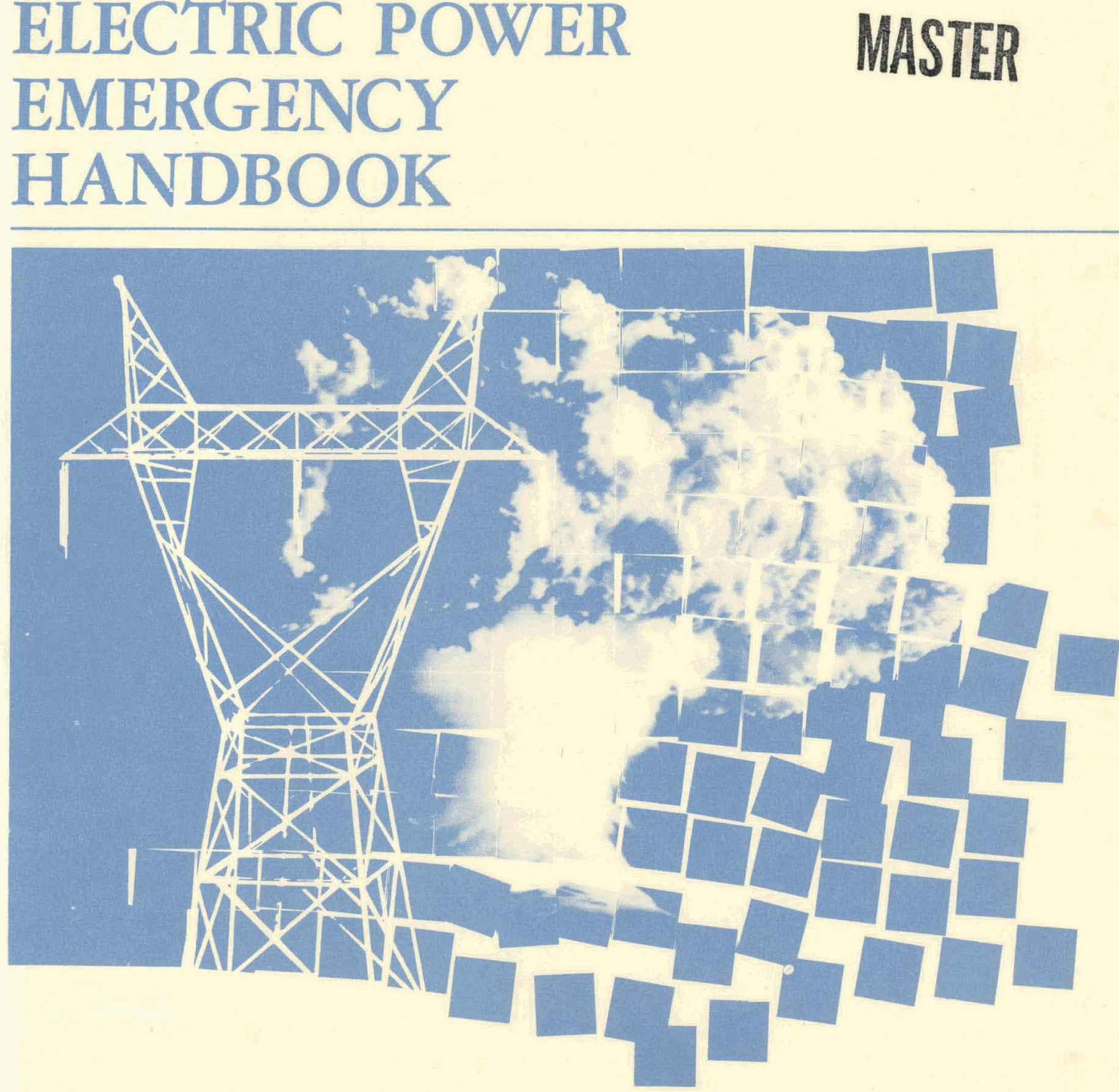


\section{DISCLAIMER}

This report was prepared as an account of work sponsored by an agency of the United States Government. Neither the United States Government nor any agency Thereof, nor any of their employees, makes any warranty, express or implied, or assumes any legal liability or responsibility for the accuracy, completeness, or usefulness of any information, apparatus, product, or process disclosed, or represents that its use would not infringe privately owned rights. Reference herein to any specific commercial product, process, or service by trade name, trademark, manufacturer, or otherwise does not necessarily constitute or imply its endorsement, recommendation, or favoring by the United States Government or any agency thereof. The views and opinions of authors expressed herein do not necessarily state or reflect those of the United States Government or any agency thereof. 


\section{DISCLAIMER}

Portions of this document may be illegible in electronic image products. Images are produced from the best available original document. 


\title{
NOTICE
}

This report was prepared as an account of work sponsored by the United States Government. Neither the United States nor the United States Depertment of Energy, nor any of their employees, makes any warranty, express or implied, or assumes any legal liability or responsibility for the accuracy, completeness, or usefulness of any information, apparatus, product, or process disclosed, or represents that its use would not infringe privately owned rights. Reference herein to any specific commercial product, process, or service by trade name, mark, manufacturer, or otherwise, does not necessarily constitute or imply its endorsement, recommendation, or favoring by the United States Government or any agency thereof. The views and opinions of authors expressed herein do not necessarily state or reflect those of the United States Government or any agency thereof.

\author{
Avallable from: \\ National Iechnical Information Service (NIIS) \\ J.S. Department of Comerce \\ 5285 Port Royal Road \\ Springifeld, VIrginia 22161 \\ Price: Printed copy: $\$ 7.00$ \\ Hicrofiche: $\$ 4.00$
}




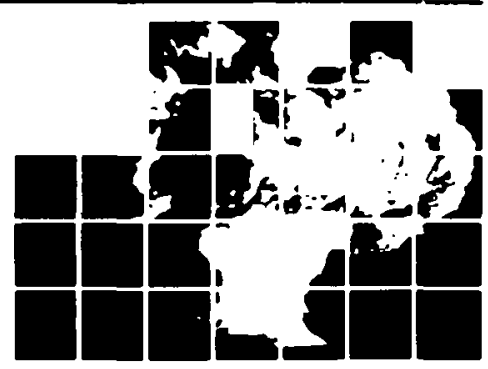

\section{Preface}

National mobilization is at best a cumbersome and lengthy process; expansion of production to maximum levels can be delayed through serious imbalances and organizational difficulties. In addition the onset and recognition of a national emergency are likely to occur much faster than mobilization can proceed.

The availability of electric power is critical to national survival and recovery for both military and oivil functions, and it is necessary to ensure the supply of electric power during national emergencies. Prudent preparations begin with legal authorization to proceed, an organizational structure, and procedures which outline a general approach. Authority is grounded in various Acts of Congress and Executive orders. The organization exists in the Emergency Electric Power Administration field structure, although the federal entity has changed in basis and character. Procedures flow from the National Plan, with the EEPA Handbook providing the interpretive guidelines for operating procedures that are unique to electric power. State plans will be measured for consistency with the EEPA Handbook.

The Emergency Electric Power Administration's Emergency Operations Handbook is designed to provide guidance to the EEPA organization. It defines responsibilities and describes actions performed by the government and electric utilities in planning for, and in operations during, national emergencies. The EEPA Handbook is reissued periodically to describe organizational changes, to assign new duties and responsibilities, and to clarify the responsibilities of the government to direct and coordinate the operations of the electric utility industry under emergencies declared by the President. This Handbook is consistent with the assumptions, policies, and procedures contained in the National Plan for Emergency Preparedness.

The survival and recovery of electric power systems are of concern to both the government of the United States and the nation's electric: power industry. The Secretary of Energy has been tasked by the President with the responsibility for planning (in conjunction with the Federal Emergency Management Agency) to provide adequate electric power to meet all emergency situations. Electric utilities, which are generally the sole source of electricity, are responsible for maintaining continuity of electric power supply to meet emergency needs. Consequentiy, the government and industry have formed a voluntary partnership to develop an effective electric power emergency preparedness plan. It is the responsibility of the Secretary of Energy to ensure effective coordination between government and industry in the event of a declared national emergency.

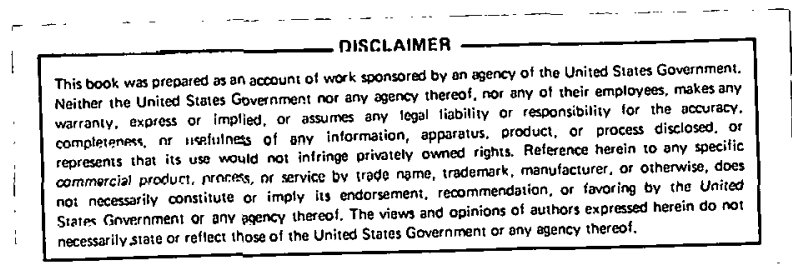




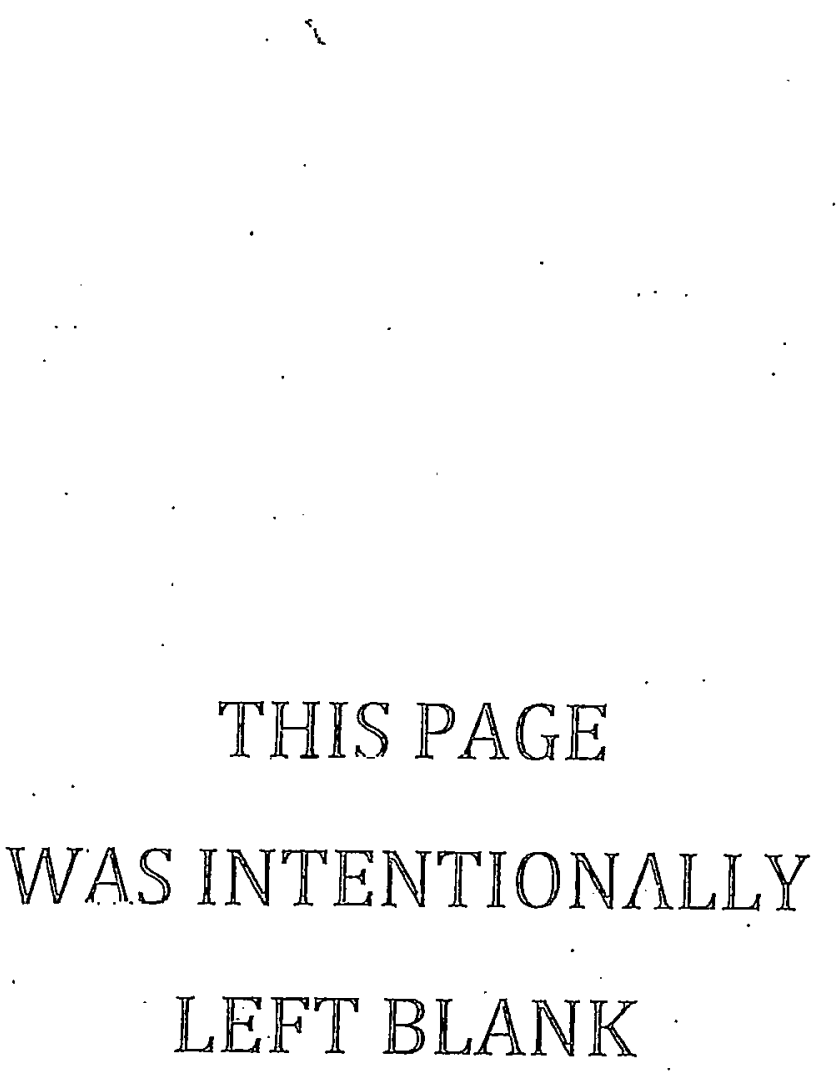




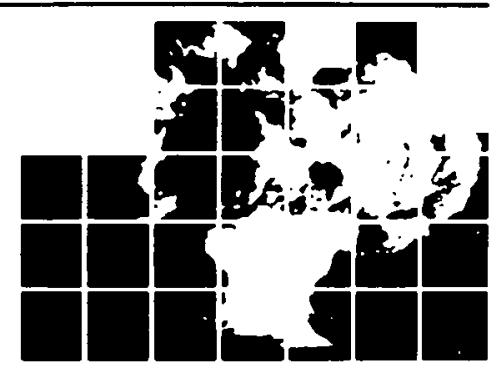

\section{Contents}

Page

PREFACE . . . . . . . . . . . . . . . . . . . .

CONTENTS. . . . . . . . . . . . . . . . . . iii

BASIC PLAN. . . . . . . . . . . . . . . . . . . 1

APPENDICES :

Appendix A EEPA Organization \& Responsihilities. . A-1 Appendix B EEPA Emergency Succession; Area Map . . . B-1

Appendix C EEPA Roster . . . . . . . . . . . . . . . C-1

Appendix D Increased Readiness . . . . . . . . . D-1

Appendix E Emergency ofperations . . . . . . . . . . E-1

Appendix F Claimancy \& Restoration . . . . . . . F-1

Appendix G Communications \& Warning. . . . . . . . . G-1

Appendix $\mathrm{H}$ Effects of Nuclear Weapons. . . . . . H-1

Appendix I Authorities................. . I-1

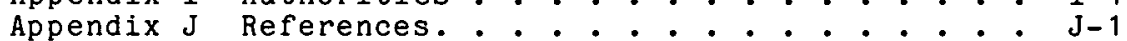

ADDENDUM:

State Plan(s) 


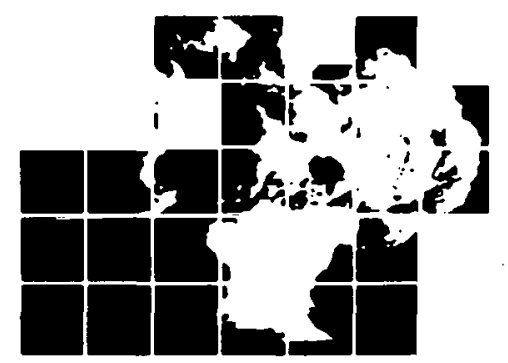

Basic Plan

I. Introduction

Emergencies take many forms: accidents, acts of God, destructive (or coercive) vandalism, international incidents, limited war, general war. Conventional procedures for responding to the first threc are available and usable with some confidence for a variety of circumstances. The last three are less likely to occur and are not at all well-defined; unfortunately, these emergencies will be most disruptive and very difficult to deal with.

The purpose of this plan is to provide some insight into the issues and concerns arising from national emergencies and to establish an organizational and technical framework for responding to emergency conditions. It is not the purpose of this plan to be an inflexible collection of rules and regulations. Rather, the rules and regulations referenced herein are provided more in the spirit of guidance. Each FEPA region is recognized as being unique in geographic distribution of facilities, dependence upon energy types and sources, nature and distribution of load, and in the procedural and legal instruments which bind the separate utilities into power pools for reasons of economy and reliability. The secondary purpose of this plan, therefore, is to illuminate these differences and their impact on the development of prudent emergency preparations.

The Basic Plan is succinct, and the bulk of the detail is to be found in the Appendices. EEPA expects to revise the Basic Plan infrequently and the Appendices as necessary.
II. Organization and Responsibilities A. Legislative Base (full text in Appendix I)

\section{Statutory authorities}

a. Defense Production Act of 1950 , P.L. 774, as amended, authorizes the use of priorities and allocations for materials and farilities; authorizes financial assistance for expansion of productive capacity and supply; provides for the employment of persons of outstanding experience and ability for emergency functions; and allows the use of voluntary agreement to ensure essential production.

b. Federal Civil Defense Act of 1950, P.L. 920 provides for a system of civil defense for the protection from attack of life and property in the United States. The responsibility for civil defense shall be vested jointly in the Federal Government and the several States and their political subdivisions. The Federal Government provides direction, coordination, guidance, and necessary assistance and provides for procurement, by condemnation or otherwise, of material and facilities for civil defense.

c. National Security Act of 1947, P.L. 253, as amended assigns to the Office of Emergency Preparedness the functions of advising the President on the coordination of military, industrial, and civilian mobilization. Among the areas covered are: use of the nation's manpower, material, and industrial resources; maintenance, stabilization, and adjustment of the civilian economy; 
unifying federal agency activities concerned with production, procurement, distribution, or transportation of supplies, materials, and products; potential supplies of, and potential requirements for, manpower, resources, and productive facilities; reserves of strategic and critical material and the strategic relocation of industries, services, government, and economic activities.

\section{Executive Orders}

a. Executive Order 11490, as amended by E.0. 11921, assigns national emergency planning and preparedness functions to the several departments and agencies of the Federal. Government.

b. Executive Order 12148 establishes the Federal limergency Management Agency, deflues the Agency's authorities and responsibilities, and transfers the functions of various other federal agencies.

\section{Defonse Monilization orders}

a. DMO 3, "Defense Production: Priorities and Allocations Authorities," establishes policy guidance in accordance with section 101 of Executive order 10480 and Section 401 of Executive Order 11051 ; delegates priority and allocation authorities in accordance of section 201 of Executive Order 10480, as amended; delegates other authorities under the Defense Production Act of 1950 , as amended.

b. DMO 4, "Guidance on Priority Use of Resources in Immediate Postattack Period," lists items cosential to national survival; provides guidance to Federal, State and local governments on the priority and use of post-attack resources.

c. DMO 11,"General Policies for Strategic and Critical Materials stockpiling."

\section{B. Federal Agencies}

1. Federal Emergency Management Agency

a. Organization: FEMA, an independent agency reporting directly to the President, has incorporated entirely the organization and functions of the Defense Civil Preparedness Agency (DOD), the Federal Disaster Assistance Administration (HUD), and the Federal Preparedness Agency (GSA). FEMA is composed of a headquarters organization in Washington, D.C. and ten Federal regions.

b. Responsibilities: The Federal Emergency Management Council, chaired by the Director of FEMA, establishes overall policy guidance and direction for the national civil preparedness effort. Reponsibilities of FEMA include: coordination of national planning for civil defense and mobilization; emergency resource management; disaster relief and emergency assistance to state and local governments; development and operation of a national civil defense warning and communications system.

2. Emergency Electric Power Administration, Department of E'nergy

a. Organization: The EEPA organization consists of a small Headquarters group and a widely de-centralized field organization. The EEPA rield structure consists of nine geographioal power at teas whosc boundaries aro related to coordinated power pools and are contiguous with the National Electric Reliability Council (NERC) Regions, plus Hawaii, Alaska, Puerto Rico, and the Virgin Is)ands (see Appendix $B$ ). The field organization is composed of persons presently employed in the electrio power industry. The organization of each power area consists of an EEPA Area Director, assisted by one or more Deputy Directors, and Regional Power Liaison Representatives who are appointed by the secretary of Energy as Special Government Employees Without Compensation (WOC). The EEPA Area Director, in consultation with the EEPA Administrator, appoints State Power Liaison Representatives and Major Utility Representatives.

b. Responsibilities: EEPA is the federal resource manager for electric power in the event of a declared national emergency. EEPA's responsibilities include: prior planning for emergency preparedness in electric power; allocation of available pnwer during emergency situations; determination of priorities for curtailment and restoration of electric power. EEPA is the claimant agency for all electric power. (See Appendix F.)

\section{State and Local Governments}

1. Pre-emergency responsibilities: State and local governments are responsible for preparing plans and procedures for disaster preparedness, emergency operations, and state resource management. Such plans should be compatible with federal guidelines and plans. In addition, State and local governments should coordinate with other governmental entities, federal regions, and private utilities in order to ensure efficient operations during a national emergency.

2. Emergency actions: State and local governments will be responsible 
for the allocation of electric power within the guidelines and resource categories specified by the Federal Government. In addition, they will be responsible for the local enforcement of curtailment orders as required by national priorities.

D. Electric Utilities. Electric utilities will be responsible for the efficient operation of facilities, damage assessment and reporting and restoration of damaged facilities under the guidance of EEPA. Within their capabilities and operating under federal guidelines, utilities would comply with requests from local, state, and Federal agencies to supply electric power for essential uses, invoking mutual aid agreements and coordinating actions with state and federal officials, as appropriate.

\section{III.Mission and Situation}

A. The mission of EEPA is to develop and maintain an adequate mobilization base and organization for electric power capable of meeting defense and essential civilian electric power requirements under a declared national emergency.

\section{B. Situation}

1. War (limited or general) with a foreign power would disrupt the normal operation of the American economic system, and an actual attack upon the United States would add physical damage to that disruption. An exchange of nuclear weapons at various intensity levels would greatly increase the damage to production facilities and the economic infrastructure.

a. It would be counterproductive for an enemy to target all of the nearly 3,000 electric utilities in the United States. However, the relatively small number of electric utilities that supply the largest fraction of the nation's bulk power should be considered as high value targets. Blast and collateral damage could disrupt generation, transmission, distribution, and communication systems. Although large generators are relatively impervious to blast effects, buildings and control systems are not. Damage to associated structures and components could render a generator inaccessible or inoperable.

b. Electro-magnetic pulse, associated with high-altitude nuclear detonations, can damage control, communication, and computer systems.

c. Fallout radiation hazard and casualty losses among trained personnel could impede recovery operations.
2. Declared national emergency. General mobilization prior to hostilities or other large-scale emergencies would affect the strategic capabilities of the nation. Both cases would require the allocation of scarce resources and the re-ordering of priorities for the use of industrial production and raw materials in the pursuit of national goals.

3. Recovery and reconstruction will require priority decisions reflecting national interest. Prior planning and identification of system vulnerabilities can substantially reduce the impact of the disruption in manpower, materials, and industrial productive capabilities caused by an enemy attack.

C. Assumptions and Definitions

1. A "declared nationàl emergency" is a declaration by the President of the United States invoking certain emergency authorities granted by Congress in order to deal with circumstances ( $s u c h$ as war or major catastrophe) that pose a serious threat to national survival.

2. Emergency electric power refers to all forms of electric power, including the generation, transmission, distribution, and use thereof. The term is applied to all electric power capability, regardless of ownership, except that of plants owned and operated by the Department of Energy and at military bases.

3. The war powers of the Federal Government are supreme, and it is a primary objective of the government to develop a plan to enhance the survival of all states and territories. All pre-attack planning and post-attack decisions on electric power must be directed toward the goals of national survival and recovery.

4. A nuclear attack may cause a breakdown in communications and control, isolating states and regions from the Federal Government and from each other. State and local governments will enforce federal and state laws in support of national objectives. In determining priorities for electric power use, state and local governments would be guided by established federal policies.

5. Subject to emergency controls and regulations, the provision of electric power and the construction, operation, maintenance, and repair of electric power facilities would remain in the hands of owners and operators. The distribution of electric power would continue through normal channels to the extent possible. 


\section{Concept of Operations}

\section{A. Pre-Emergency Period}

1. Develop emergency plans and preparedness programs, to include vulnerability assessments and mitigation of attack effects.

2. Maintain field organization through selection and training of personnel; conduct exercises for training and evaluation.

3. Appoint electric utility personnel as WOC employees.

\section{B. Emergency Period}

1. Expand Headquarters staff; activate field organization on a full-time basis.

2. Determine capabilities and requirements for electric power through coordination with state and regional agencies.

3. Allocate power, order wheeling and interconnection, as required.

4. Estimate surviving capacity to support national goals.

5. Establish priorities for the curtailment, allocation, and restoration of electric power.

6. Act as claimant agency for electric power.

\section{Lines of Authority}

1. The Secretary of Energy has been given certain emergency authorities to be used in the event of a national emergency. The secretary has in turn delegated certain of those authorities to EEPA Headquarters and field officials.

2. EEPA has the authority to allocate power, to order curtailment of non-essential electric power use, to order wheeling of power and necessary emergency interconnections, and to direct the restoration effort for electric power.

3. Under the direction and guidance of EEPA Headquarters, Area Directors exercise the EEPA authorities within each power area. The Area Director communicates directly (or through a deputy) with the Major Utility Representatives to order load shedding, wheeling, restoration, and interconnection. Close coordination with state and federal regional authorities is necessary to ensure the most productive use of electric power resources in support of national goals.

4. State and local governments could establish priorities for the use of electric power within their respective jurisdictions. They would assist in issuing and would enforce orders curtailing less essential uses of electric power. State and local governments would not assume responsibility for the performance of any function reserved to EEPA unless the required action could not be carried out by EEPA. Nor would the state and local governments assume responsibility for technical direction of electric power generation, transmission, or distribution operations, except those in which they are normally engaged.

If, after curtailment, power were not available to meet all essential needs, the state or local government would determine the order of priority among power users within its jurisdiction. If the conflict affected uses in another jurisdiction, it would refer the matter to the next higher level of government.

5. EEPA/FEMA relationship: FEMA is the coordinator for all national resources and sets general guidelines and priorities for national resource management; EEPA directly controls and manages electric power resources to meet FEMA guidelines.

V. Communications and Control

A. Communications (ref. Appendix G). Electric power communication facilities perform a large number of industry functions including voice communications, teletype, telegraph, remot.e control and supervision, protective relaying, system loadfrequency control, telemetry, alarm, and other information transmission. These functions are provided by utility-owned power line carrier, telephone lines, telephone line carrier, radio and leased common carrier facilities. Such facilities are so integrated with the generation, transmission, and distribution of electric power that they are an integral part of the power system.

The Federal Communications Commission, by Executive Order 11092 , has been assigned the responsibility to prepare national emergency plans and develop preparedness programs covering the provision of service by common carriers, broadcast facilities, and the safety and special radio services. The Federal Communications Commission is the claimant agency for all telephone and telegraph common carriers and radio and IV broadcasting companies serving the general public, excluding governmentowned and operated telecommunication facilities, and excluding those telecommunication facilities owned 
and operated by businesses for their own use.

\section{Emergency Communication Requirements}

a. In the event of a general war involving an attack on the United States, the EEPA Headquarters organization will be activated at a relocation site and will control emergency actions applying to electric power. However, since an attack would likely interrupt communications between EEPA Headquarters and Area Directors, principal reliance for emergency operations will be placed on the field organization until communications can be restored.

b. The effectiveness of immediate post-attack emergency aotiono will depend on the ability or Area Directors to communicate with the rest of the field organization. Area Directors must have adequate communication with EEPA Headquarters during the recovery period.

c. Utility-owned and leased communication facilities that are used in daily operations will function as a basic part of emergency communication requirements. To the extent they consider economically justified, electric utilities will provide supplemental, alternate, and standby communication facilities for use under emergency conditions.

d. Communication facilities required solely for carrying out EEPA functions will normally be furnished by the Federal Government (through EEPA), although electric utilities may elect to furnish those that may later be useful for operating functions.

e. A summary of the more essential communication requirements sponsored and supported by EEPA follows:

\begin{tabular}{lcc} 
Between & $\begin{array}{c}\text { Utility } \\
\text { Furnish }\end{array}$ & $\begin{array}{c}\text { Government } \\
\text { Furnish }\end{array}$ \\
\hline $\begin{array}{l}\text { Utility management and } \\
\text { operating facilities }\end{array}$ & $\mathrm{X}$ & \\
$\begin{array}{l}\text { Utility operating facilities } \\
\begin{array}{l}\text { Operating facilities of } \\
\text { interconnected utilities }\end{array}\end{array}$ & $\mathrm{X}$ & \\
$\begin{array}{l}\text { Utilities and local civil } \\
\text { defense offices }\end{array}$ & $\mathrm{X}$ & $\mathrm{X}$ \\
$\begin{array}{l}\text { Utilities and Area Director } \\
\begin{array}{l}\text { Area Director and State Power } \\
\text { Liaison }\end{array}\end{array}$ & $\mathrm{X}$ & $\mathrm{X}$ \\
$\begin{array}{l}\text { Area Director and Regional } \\
\text { Power Liaison }\end{array}$ & & $\mathrm{X}$ \\
$\begin{array}{l}\text { Area Director and EEPA } \\
\text { Headquarters }\end{array}$
\end{tabular}

\section{EEPA Responsibilities}

a. EEPA periodically reviews with electric utilities the capability of their communication facilities to determine if additions are required for the administration of national controls under emergency conditions.

b. EEPA Headquarters periodically reviews, with each Area Director, the emergency communication facilities furnished by the Federal Government to determine additional requirements.

c. Area Directors provide guidance for emergency planning and encourage electric utilities to provide emergency communication facilities required to ensure reli- able operation under emergency conditions. EEPA has considered expanding the use of two-way radio and, when required, assists utilities in procuring appropriate frequency assignment from the FCC.

d. EEPA is the claimant agency for the electric power industry's required supporting resources. Utility-owned communication facilities are treated in the same manner as other operating facilities. EEPA will survey electric utility communication requirements, analyze them to determine priorities, and then submit requests to the FCC or other appropriate resource agency.

e. During emergencies, EEPA will evaluate the need for common carrier facilities leased by electric 
utilities and will assist in resolving any conflicts that develop in priorities assigned for use, repair, or restoration.

\section{Electric Utilities' Respon- sibilities}

a. Analyze communication systems to identify needs and make plans for expansion to ensure reliable interpool and intrapool operations.

b. Assist the EEPA Area Director in analyzing the need for supplemental, alternate, and standby communication for administering national controls under emergency oonditions.

c. Maintain communication systems in a readiness condition to ensure reliable service for emergency conditions.

d. Under alert conditions, check the readiness of alternate facilities and place them in operation when requested by the Area Director.

e. Arrange for needed common carrier facilities and radio frequencies, in accordance with existing priority procedures. Priority requirements which are unobtainable will be referred to EEPA, which will evaluate the need and provide the necessary assistance.

\section{Wartuling}

Key EEPA personnel will be alerted under emergency conditions through the existing government warning system (NAWAS). The present attack warning system is a mixture of Federal, state, and local networks. NAWAS is a two-way partyline telephone system. It may be used for natural disasters and other peacetime emergencies, as well as for nuclear attack.

The Federal portion of NAWAS connects three National Warning Centers with approximately 945 full-time state and local warning points. Warning officers at the Warning Centers initiate a voice warning message. It takes about one minute for the message to reach the warning points. From the 945 Federally-warned points, further dissemination of the warning is made through police or other radio or telephone networks to reach outlying cities and towns. Each state has its own intra-state warning system. Time to alert the public beyond the NAWAS points varies from a few minutes to more than 20 .
5. Problems and Deficiencies

a. The EEPA Communications Plan is presently being revised and will be published as Appendix $G$ of this Handbook. Since EEPA has no organic communication system, it must rely on existing utility and power pool networks and on communication systems operated and maintained by other government agencies. Thus, EEPA communications are vulnerable to preemption and line overload on non-dedicated circuits. The increasing sophistication and sensitivity of modern communications systems make them vulnerable to blast and EMP effects.

b. Studies are necessary at every level of the EEPA organization: to assess the vulnerability of communications systems to wide area nuclear effects; to determine the types of communication facilities needed (voice, teletype, leased line, in 1 crowave, ladio net, eto.); to prepare plans, procedures, and networks that will afford an adequate emergency communications capability.

c. A flexible and responsive, yet positively-controlled, system of warning, notification, and message authentication will be developed by the EEPA Headquarters staff.

\section{B. Control}

1. The succcooion of authority within EEPA is described in Appendix B.

2. Direction and control of EEPA operations will be carried out through normal EEPA organizational channels. The flow control and guldance will be from Headyuarters tu the Area Directors to the Major Utility Heprésentatives. Some EEPA areas are divided into sub-areas, with a Deputy Director responsible for the operation of each sub-area.

3. State and Regional Power Liaison Representatives represent the Area Director at the various state and regional levels within the EEPA area. They provide the Area Director with a channel for information and guidance to and from the states and federal regions.

4. If communications are lost, the highest surviving EEPA echelon will assume the full emergency authority and all functions of the EEPA Administrator and continue operations in accordance with existing policies and guidelines until communications are re-established. 
VI. Special Concerns

A. Electro-Magnetic Pulse (EMP)

1. Nature of the Threat

The detonation of a nuclear weapon at altitudes above $50 \mathrm{~km}$ produces gama radiation which interacts with the atmospheric level between 20 and $40 \mathrm{~km}$ above the earth's surface. This interaction (Compton scattering) in turn produces electrons which are radiated downward from the atmosphere. In effect, the entire atmosphere becomes an antenna, radiating the electro-magnetic pulse.

A nuclear weapon detonated at an altitude of $100 \mathrm{~km}$ would affect an area on the ground of $1,200 \mathrm{~km}$ radius. A weapon detonated $400 \mathrm{~km}$ directly ovor Kanoas would affecl nearly the entire United States. The pulse produced by a high-altitude nuclear explosion is one of high intensity, short duration, and large effective radius. It is possible that a missile attack would consist of several precursor warheads to disrupt communication warning systems, followed by the main attack.

2. Effects on Electric Power Systems

a. The problems caused by EMP lie in the high electrin field strength $(90 \mathrm{kv} / \mathrm{m})$ and the short rise-time ( 10 nanoseconds). These characteristics can produce very large and fast transient voltages in the long, unshielded conductors of power systems. These transients are like lightening surges but have a much faster rise-time. In addition, EMP would affect large portions of an extended system simultaneously.

b. The high insulation level of transmission lines will probably prevent damage from EMP to the lines. Distribution lines are less robust and more subject to induced faults. In any case, induced voltages at line terminations and junctions will be higher than in long, straight portions, and faults at substations are likely.

c. EMP-induced surges could cause circuit-breakers to open, protecting lines and circuits. However, multiple EMP events could easily cause circuit breakers to lock out, resulting in a sudden loss of load.

d. Solid-state relays are espeoially vulnerable to damage from EMP surges. Although solid-state devices usually have electro-mechani- cal backup relays, repeated surges could cause a failure that would trip out the line.

e. EMP-induced transients, both in the power system and in generator control circuits, could result in generator trip-out due to overspeed or underspeed.

f. The components most vulnerable to EMP are the solid-state control and diagnostic computers used in dispatch centers, as well as communication and control systems. operational malfunction, false indications, memory erasure, and actual physical damage to components can be caused by EMP-induced transients.

\section{EEPA and Industry Response}

d. Further research is necessary to assess the vulnerability of electric power systems to EMP (especially in view of the increasing interconnection of major power systems), and to develop plans for minimizing the damage caused by both blast effects and EMP.

b. The thrust of industry planning for the EMP threat seems to be reactive and restonative rather than anticipatory. It is difficult to isolate large portions of a power system in advance, and utilities plan t.n rely on replacoment or ropair of damaged parts to restore service. However, the potentially large radius of an EMP surge (or several surges) could affect power systems throughout the nation. The consequent demand for spare parts could put a severe strain on inventories. In addition, an attack situation could seriously hamper the transfer of equipment to where it is needed. Planning is necessary to ensure that an adequate supply of spare equipment is maintained, or that it can quickly be obtained in a crisis.

c. Power pools and individual utilities should identify the most essential components of their computer, control, and communication systems and protect them. Fortunately, the most essential equipment is usually the easiest to protect through shielding, filtering, and isolation.

B. Crisis Relocation Planning (CRP)

\section{Program Overview}

The civil defense concept, "crisis relocation," involves the strategic withdrawal of population from the cities during an international crisis. Crisis relocation 
planning and testing is currently the responsibility of the Federal Emergency Management Agency. Metropolitan areas that are likely to be targets during a nuclear war are identified as "risk areas"; they are matched with "host areas" (areas of little target value) which would receive the evacuated population and provide shelter, food, and other services for a period of $2-4$ weeks. Some fraction of the metropolitan population (about 20\%) would remain to provide needed services--security, fire protection, maintenance. of these workers, some would live in the city, and some would live just outside the risk area and commute to work.

One part of crisis relocation i.s referred to as "organizational, relocation" and refers to the assignment of people to host areas oased un business or plant affiliation rather than census tract. Suoh a relocation plan would keep skill and management structures intact, provlde a eertain organizational discipline and pool of usable skills in the host area, and enhance the return to normal operations during a recovery and restoration period. At present, organizational relocational planning is one of several alternatives being considered by FEMA in support of crisis relocation planning.

2. Impact on electric Power

a. Load in the host areas will most likely not increase at the same rate as the population, so that overloading is less of a problem over the short term. In addition, surplus capacity in the risk areas can be transferred to accommodate the increased load. However, crisis relocation followed by a nuclear exchange--with the attendant damage to generation, transmission, and distribution systems--could significantly alter the normal patterns of electric power supply. Both the maintenance of supply to host areas and the restoration of power in damaged areas would be a continuing problem.

b. While some administrative activities could be temporarily suspended--clerical, billing, scheduled maintenance--a certain minimum work force would be required to maintain utility facilities and correct malfuntions.

c. Restoration of electric supply or, assuming that the crisis ends short of war, return to normal operations would be of immediate priority.

\section{EEPA and Utility Response}

a. Both the EEPA organization and utility systema ahnuld incorporate crisis relocation into their planning process. Load, capability, and vulnerability studies should be examined to identify probable patterns of load shifting, and to determine where emergency interconnections can best be made if necessary.

b. Electric utilities should establish procedures for ensuring the security, stability, and integrity of systems under conditions of reduced load and reduced personnel manning.

c. Power pools and electric utilitico should consider organizational relocation as a method of ensuring both the safety of skilled employees and the speedy restoration of electric power. 


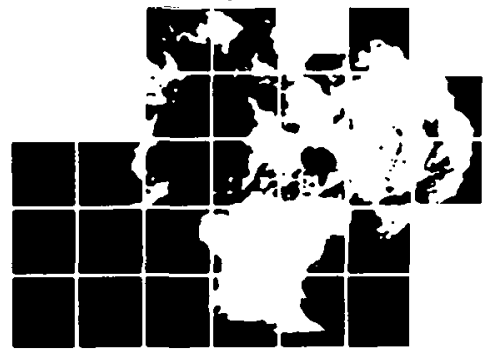

\section{EEPA}

\section{Organization \& Responsibilities}

I. This Appendix describes the pre-emergency organization and responsibilities of EEPA. Emergency operations are described in Appendix E.

II. Organization

A Headquarters

The Headquarters organization, in Washington, D.C., is composed of a full-time staff. In an emergency, EEPA Headquarters would be enlarged by the addition of senior executives selected from the utility industry, the Division of Power Supply and Reliability forming the nucleus of the Expanded Organization.

\section{B. Field}

The EEPA field structure consists of nine geographical power areas whose boundaries are related to coordinated power pools and are contiguous with the National Electric Reliability Council (NERC) Regions, plus Hawaii, Alaska, Puerto Rico, and the Virgin Islands.

Each Area is managed by an Area Power Director, assisted by one or more deputies and Regional Power Liaison Representatives. In addition, Area Directors are assigned by electric industry personnel serving as EEPA State Power Liaison Representatives--one or more for each state and one each for the District of Columbia, Puerto Rico, and the Virgin Islands--and Major Utility Representatives chosen from each major utility in the EEPA area.
Through this network, preparedness activities of the electric power industry and the Federal, State, and local governments are closely coordinated to ensure effective resource management during periods of declared national emergency.

\section{Responsibilities}

\section{A. Hear quarters}

\section{General}

The EEPA Headquarters is responsible for the development of emergency plans and preparedness programs and for the maintenance of a field organization in readiness. Readiness activities will consist of the selection and training of competent volunteers who are currently employed in the electric power industry.

\section{Administrator}

The Administrator of EEPA provides direction and leadership to the emergency preparedness program in electric power. The Administrator supervises and coordinates the emergency planning efforts of a small full-time staff and the WOC personnel serving as principal officials of the EEPA organization. The Administrator provides for an appropriate emergency operating center (EOC) and designates the order of succession to positions in EEPA. As part of preparedness responsibilities, the Administrator makes prior arrangements with other federal agencies concerning electric power emer'gency functions. 


\section{Staff}

The EEPA staff, under the direction and supervision of the Administrator, develops emergency plans and programs and encourages full readiness in the industry. The staff assists with recruitment and training of personnel; reviews and maintains emergency programs and operating procedures on a current basis; and conducts and/or participates in simulated emergency exercises.

\section{B. Field}

Area Directors, Deputy Area Directors, and Regional Power Liaison Representatives are appointed by the Secretary of Energy as "special government employees" on a withoutcompensation (WOC) basis. They assist the Administrator in carrying out the pre-emergency functions of the EEPA organization. All of the appointees are presently employed in the electric power industry.

Deputy Alea Dircetoro aro selected from widespread localities within the EEPA areas to ensure that at least one will be available in a post-attack situation. In those areas where one of the ten FEMA Regional offices is located, a Regional Power Liaison Representative is designated to represent EEPA at these regional offices. He will be selected from the electric utility closest to the FEMA office to which he is assigned.

EEPA State Power Liaison Representatives are designated by the Area Director in consultation with electric utilities and the Administrator of EEFA. If parto of more than one EEPA area lie within a state, the selection and designation of the state Power Liaison Representatives will be made jointly by the Area Directors concerned. Selection of persons for this office should anticipate that at least one of them would be at the State's emergency operating center under emergency conditions.

EEPA Major Utility Representatives are designated by the Area Director. It is left to the discretion of the Area Director to select those utilities of sufficient importance to identify an EEPA Major Utility Representative in advance.

Both State Power Liaison Representatives and Major Utility Representatives will remain electrir utility employees while serving : their assigned positions. The designations are made with understanding that the utili where they are employed will th them available in an emergency to devote as much time to their assigned duties, and for as long a period, as the emergency situation requires. The appropriate state emergency preparedness officials should be kept advised of those individuals designated as State Power Liaison Representatives and Major Utility Representatives.

The key to success of emergency preparedness is at the utility level where every company should develop omergenoy plans in close cooperation with local civil defense plans and with the guidelines of Federal and state governments.

\section{Area Director}

a. Assist the Administrator in choosing qualified personnel to serve as Deputy Director, state/ Regional Power Liaison, Major Utility Representative.

b. Maintain the state of readiness in the EEPA ares. Periodic analyoio, training, and oxeroise of personnel and procedures is required to ensure the effective operation of the EEPA organization.

c. Encourage electric utilities to develop and maintain mobilization plans, damage assessment procedures, and damage limiting strategles.

d. Maintain an emergency operating center (EOC), properly equipped with necessary documents, information, plans, data processing resources, and an emergency staf for the direction of operations within the EEPA area.

e. Ensure adequate communications with deputies, state/ Regional Liaisons, Major Utility Representatives. Maintain warning and fan-out SOP's

f. Advise the EEPA Administrator of current preparedness status, problems, deficiencies.

\section{Deputy Area Director}

a. Assist the Area Director in carrying out preparedness responsibilities.

b. In the absence of the Area Director, assume full responsibility for the duties of the Area Director and report directly to the EEPA Administrator.

c. Maintain and properly equip an alternate EOC and an emergency staff capable of performing the functions of the Area Director should that be required. 


\section{EEPA Regional Power Liaison Representative}

a. Assist the Area Director in coordinating EEPA activities with the Federal Emergency Management Agency.

b. Advise the FEMA Regional office of electric utility preparedness based on reports of Area Directors in the Region.

c. Advise the Area Director and EEPA Headquarters of FEMA plans affecting electrical power in the Region.

d. Participate in periodic preparedness training exercises.

e. Ensure that an office at the FEMA Regional EOC is equipped with the necessary documents, information, and materials to carry out emergency operations, including provision for direct communication with the Area Directors(s).

4. EEPA State Power Liaison Representative

a. Assist the Area Director and serve as liaison on electric power matters at the state EOC.

b. Inform the state emergency planning staff of electric utility preparedness within the slale specifically related to the EEPA program. c. Advise the Area Director and utilities of State plans affecting electric power.

d. Participate in periodic training exercises.

e. Ensure that an office at the state EOC is equipped with the necessary documents, information and materials to carry out emergency operations, including provision for direct communication with the Area Director.

\section{EEPA Major Utility Representative}

a. Serve as contact at the electric utility for EEPA officials and for the state Power Liaison Representative.

b. Advise the local government emergency planners of electric utility preparedness.

c. Advise the state Power Liaison and the utility represented of local plans affecting electric power.

d. Participate in periodic training exercises.

e. Maintain a company EOC equipped with the necessary documents, information, and materials to carry out emergency operations.

\section{Emergency Electric Power Administration Headquarters and Field Organization}

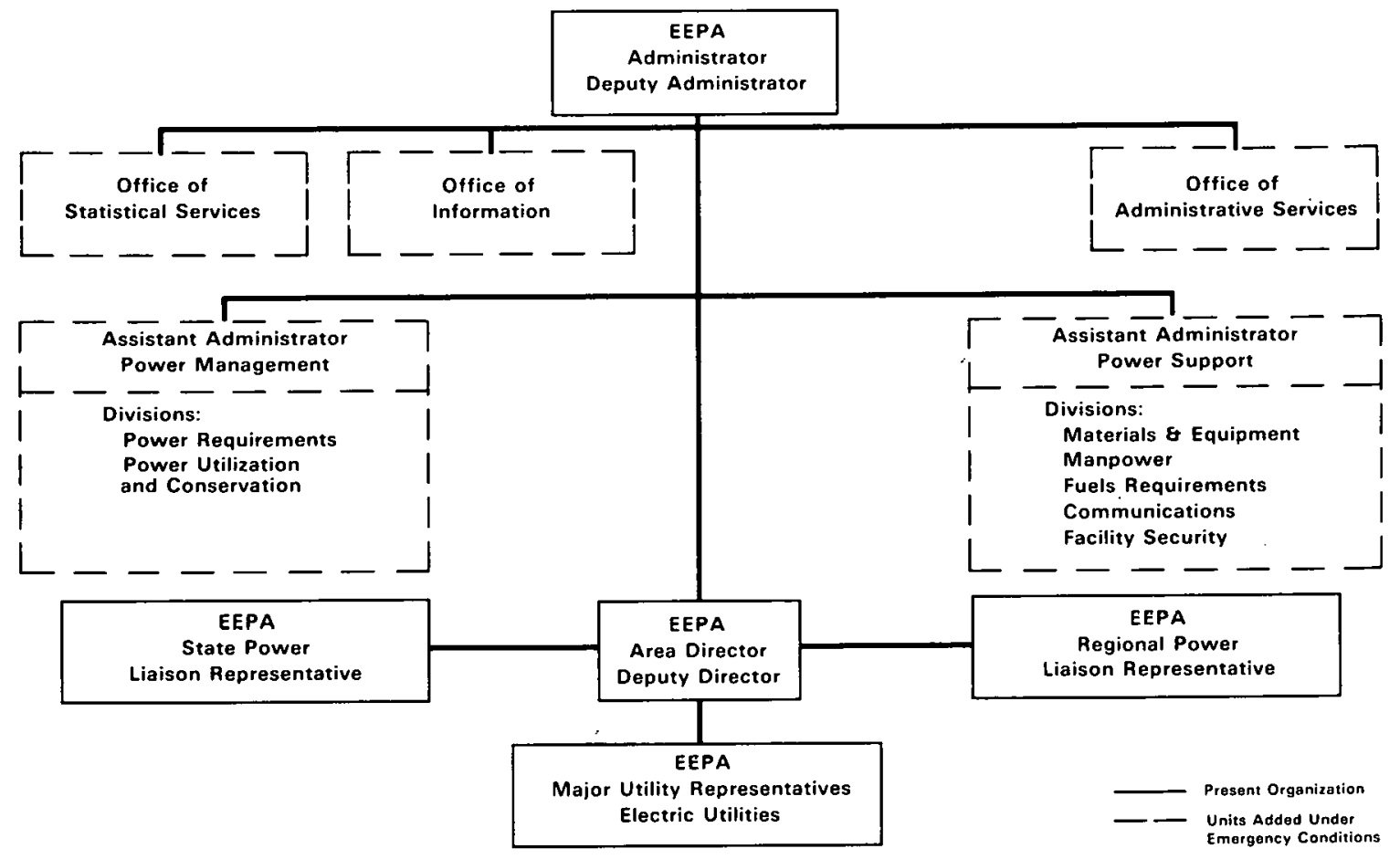


Appendix B

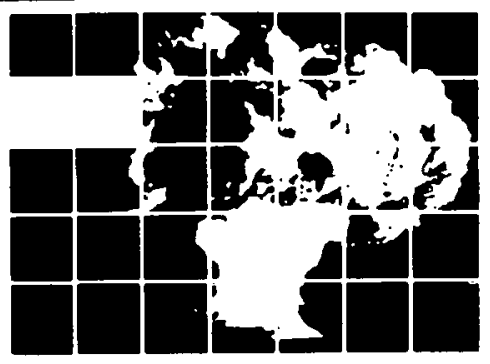

(This Appendix is being developed by an EEPA Task Group)

The Emergency Electric Power Administration is working with the Federal Emergency Management Agency (FEMA) in developing this succession list. 


\section{EEPA AREAS}

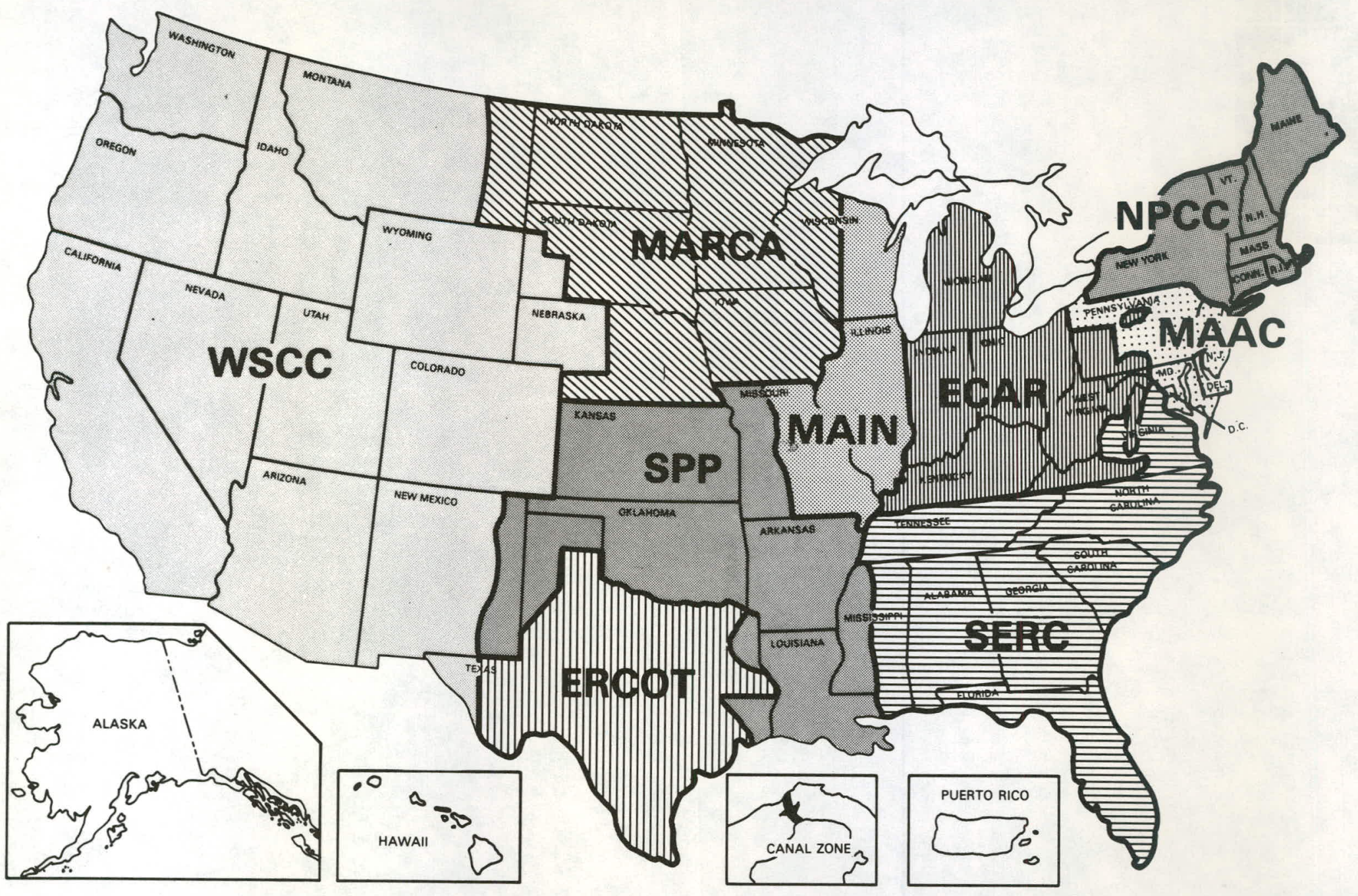


Appendix C

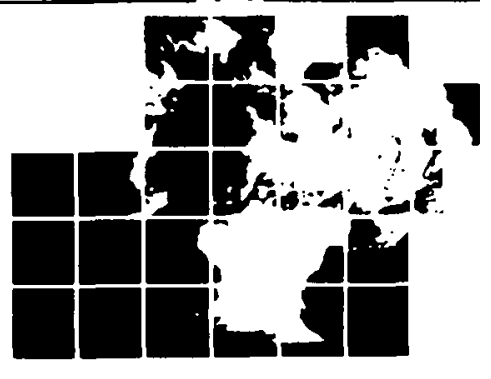

This roster is periodically updated (January and June of each year) and issued separately. 


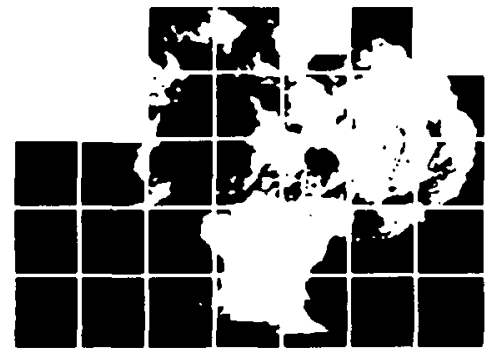

\section{Increased Readiness}

I. Readiness Posture

In order to allow a smooth and timely transition to emergency operations, certain procedures and actions are carried out to plan EEPA in a more responsive condition prior to an actual emergency.

\section{A. Directory of Key Personnel}

EEPA Headquarters publishes and distributes a roster of EEPA and FEMA personnel in January and June of each year. The roster contains the name, address, and telephone numbers of Headquarters and field personnel, and information on key personnel in the FEMA Regional offices (see Appendix $C$ for the EEPA Roster).

\section{B. Training and Exercises}

EEPA conducts training programs for electric utility personnel periodically. These programs are held in various cities. In addition, simulated exercises are held to give EEPA personnel an opportunity to exercise their skills and to test procedures. EEPA personnel are encouraged to attend education programs provided by FEMA and other preparedness-oriented agencies.

\section{Vital Records and Data}

It is essential that vital records and other information be available at emergency operating centers. EEPA maintains a complete duplicate file at its national headquarters site as well as statistioal information and system maps of individual electric utilities. Area Directors should malntain a vitai records file at their EOC's. In most instances, they can supplement these records with carry-in records and materials which will provide the most current information.

II. Emergency Operating Centers

A. Headquarters

EEPA direction and control would have to be performed on a continuous basis during an attack or a declared national emergency. The EEPA Administrator has made provision for three national-level Emergency Operating Centers in accordance with FPC 11 . Headquarters personnel will report to the following sites in accordance with pre-emergency instructions:

1. EEPA Headquarters Primary

2. Western Virginia Alternate Operations

Division

3. Harpers Ferry, West Virginia

Alternate

B. Field Organization

EEPA Area Directors and Deputy Directors should maintain suitable EOC's near their principal business offices. Regional Power Liaison Representatives should arrange for office space in the appropriate FEMA sites listed below:

$\begin{array}{ll}\text { Region I } & \begin{array}{l}\text { Boston, MA, and } \\ \text { Maynard, MA }\end{array} \\ \text { Region II } & \text { New York, NY } \\ \text { Region III } & \begin{array}{l}\text { Philadelphia, PA, } \\ \text { and Olney, MD }\end{array}\end{array}$


Region IV

Atlanta, Ga, and Thomasville, GA

Region V

Region VI

Chicago, IL, and Battle Creek, MI

Dallas, $T X$, and Denton, $T X$

Region VII

Kansas City, MO

Region VIII

Denver, CO

Region IX

San Francisco, CA, and Santa Rosa, CA

Region $\mathrm{X}$

Seattle, WA, and Bothell, WA

State Power Liaison Representatives should arrange for space at the state EOC. Major Utility Representatives are assigned to their reopootivo nompany'g EOC!s.

\section{EOC Standards}

EEC otrongly rooommonds that Area Directors and Deputy Directors choose EOC's based on the following minimum standards:

1. Blast and shock protection

2. EMP shielding

3. Radiation Protection Factor of no less than 40 with 100 a preferable minimum

4. Emergency power, fuel, water and food supplies

5. Accomodation and sanitary facilities for sufficient personnel to allow 24-hour, two-shift operation

6. New construction can be "slanted" to provide increased protection at minimum additional coot. FEMA oan provide guidance on slanting techniques, protection factors, and stocking.

III. Readiness Levels and Actions

In the event of a build-up of international tension threatening the security of the United States, partial activation of the EEPA organization may be necessary. Such activation will be as directed by the EEPA Administrator pursuant to a decision by the Secretary of Energy. Full activation of the entire EEPA organization would occur automatically in the cvcnt of an attack on the United States.

The checklists on the following pages will be used by all EEPA echelons to place the organization in an advanced state of readiness.
HEADQUARTERS READINESS PREPAREDNESS

(Exercise Code: SPRING FEVER)

Maintain and periodically test emergency mobilization and operation plans.

1. Establish and train an efficient organization for emergency operations.

2. Establish and maintain reliable lines of communication and channels of contact with approprlale emeristicy preparedness officials.

3. Designate, prepare, and equip suitable protected places for relocation and the conduct of emergency operations.

4. Maintain and protect vilal renords and have them readily accessible.

5. Analyze the need for increased senuritiy measures to nrovide ohysical security for facilities.

6. Arrange for receipt and dissemination of emergency warning.

7. Keep next higher echelon advised of readiness status.

\section{COMMUNICATIONS WATCH}

(Exercise Code: QUICK STEP)

Review and update emergency readiness plans without public disclosure and minimum internal disclosure.

1. Kéview emergency mob1l1zaltun and operations plans and update as necessidry:

a. Prepare for installation of temporary harriers, protestive lighting, guard shelters, emergency communication faoilitios, etc.

b. Arrange for guard manpower-local auxiliary police, utility personnel, etc.

2. Ensure reliable communications for emergency operations.

3. Check relocation/operating centers and shelter management arrangements.

4. Check emergency warning and fan-out procedures.

5. Check life-support facilities, food, water, sanitation, etc., of EOC's. 
6. Review requirements of next readiness level.

7. Notify next higher echelon of readiness status.

INITIAL ALERT

(Exercise Code: TIGHT REIN)

Check general readiness with minimum public disclosure.

1. Headquarters: Activate National Office Emergency Cadre No. 1. Alert Cadre No. 2 (activate and/or relocate as necessary). Alert Cadre No. 3 .

2. Recall key personnel from leave or travel and brief them on emergency assignments and shelter facilties.

3. Man EOC's.

4. Check readiness of:

a. Emergency communications

b. Emergency operating Center

c. Shelter areas for management and key operations personnel

d. Fssential operating equipment

e. Trained radiological and decontamination teams

5. Close all key facilities to unauthorized personnel and provide access control.
6. Correct any deficiencies.

7. Review requirements of next readiness level and prepare to activate emergency plans on short notice.

8. Update records, including emergency action documents, at relocation sites.

9. Notify next higher echelon of readiness status.

ADVANCED ALERT

(Exercise Code: FLOOD TIDE)

1. Headquarters: Activate and relocate National Emergency Cadre No. 3 to appropriate EOC's. EEPA field emergency personnel. man primary and alternate EOC's.

2. Activate full security plans.

3. Notify personnel with emergency assignments to move automatically to assigned shelter areas in event of an attack warning.

4. Notify next higher echelon when plans are fully activated.

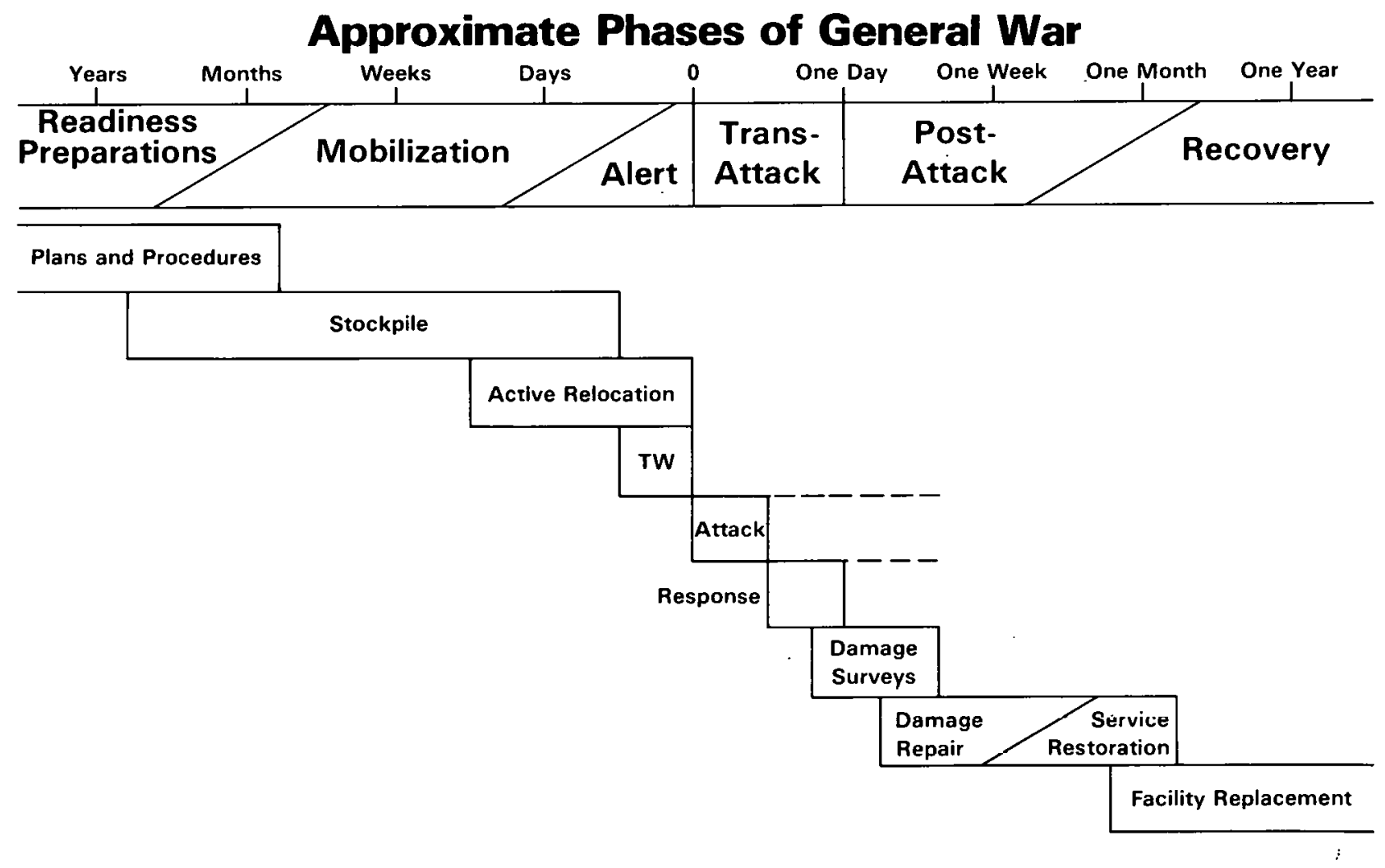


THIS PAGE

\section{WAS INTENTIONALLY LEFT BLANK}




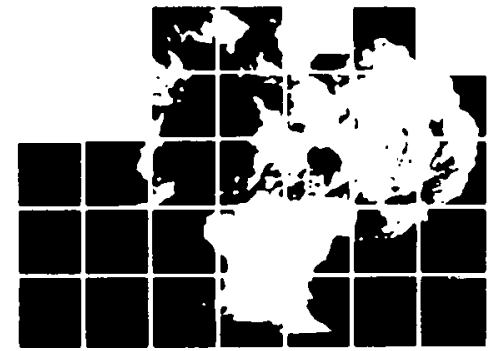

\section{Emergency Operations}

I. Emergency Organization

\section{A. EEPA Headquarters}

Under emergency conditions, the Headquarters organization will be expanded, as necessary, to implement the plans for ensuring the most effective use of electric power resources. The Secretary of Energy will appoint senior executives from the electric power industry. These new appointees will become full-time Federal Government employees in EEPA and w11l usually serve on a salary basis under government pay schedules then in effect. If personal or company circumstances should require an official to serve in EEPA without government compensation, he would be allowed to do so pursuant to appropriate legal authority. The fulltime members of the pre-emergency headquarters staff may continue to serve in the same capacity or be assigned to assist in another capacity within the expanded organization.

The Administrator will be assisted by the following personnel:

1. Deputy Administrator assists the Administrator and acts for him in case of absence.

2. Assistant Administrator (Power Management) is responsible for determining emergency power requirements, priority and allocation of electric power, and for planning system restoration and/or system expansion to meet national. electric power requirements.

3. Assistant Administrator (Power Support) is responsible for claiming materials required by the electric utilities and for allocating such materials among various segments of the industry, including those projects in various stages of planning or construction.

4. Other staff--0perating divisions under each Assistant Administrator will be assigned portions of the Assistant. Administrator's responsibilities.
a. Office of Information
b. Office of Administration
c. Office of Statistics
d. Operating Division

B. EEPA Field Organization

The pre-emergency field organization described in Appendix $A$ will be activated to the extent required by the emergency conditions. Upon activation, EEPA Area Directors and Deputy Directors will become full-time EEPA personnel and will be paid in the same manner as described above for utility executives appointed to positions in EEPA Headquarters.

II. Emergency Actions: Headquarters A. Give general direction to field operations.

B. Make load and capability studies. C. Estimate surviving national electric capacity.

1. Attack effects and damage 2. Availabilitiy of supporting resources 
3. Essential requirements for electric power

D. Allocate power, order wheeling and interconnection as needed.

E. Establish the order of restoration, repair, expansion, and construction of electric power facilities.

F. Allot material and equipment available to emergency electric power programs.

G. Issue construction authorization to the electric power industry. Coordinate with approved program and authority agency responsible for the allocation of construction materials.

H. Work with appropriate agencies in obtaining and retaining manpower, facilities, and materials for the electric power industry.

I. Act as claimant agency for electric power.

III. Emergency Actions--Field

A. Area Power Director/Deputy Area Director

1. Upon notification by the EEPA Administrator or a declaration of a national emergency, move to the emergency operating center and activate the area organization, employing personnel as necessary.

2. Advise EEPA Headquarters and appropriate Regional, State, and Utility Representatives of damage to electric power facilities, the availability of power, and expected load demands on the system.

3. Order immediate curtailment of nonessential uses of electric power to the extent necessary to ensure system operating security and stability. Enforcement of the Area Director's order will be carried out by state and local governments.

4. In the absence of specific direction on priorities from EEPA Headquarters, direct restoration of electric service in the region, complying--where possible--with civil defense and military requests for essential service.

5. Establish necessary emergency power interconnections.

6. Arrange for the transfer of manpower, equipment, and materials among electric utilities as required to meet power objectives.

7. Requisition essential equipment, materials, and supplies from utility inventories.
8. Submit requests for additional manpower, material, and equipment to EEPA Headquarters or the State Resource Management Organization through the State Power Liaison, as appropriate.

9. If the Area Director is cut of from communication with EEPA Headquarters as a result of an attack, he is authorized to take any action he deems lawful, reasonable, and necessary to maintain power supply in the area. Under such circumstances, the Area Director exercises the full emergency authority which has been delegated to the Secretary of Energy by the President with respect to electric power.

10. The Deputy Director will assist the Area Director with emergency duties.

11. In the absense of the Area Director, the Deputy Director will assime full responsibility for emergency operations in the area and will report directly to the EEPA Administrator.

12. If the Deputy Director is unable to establish communication with the Area Director, he will function as the Area Director in his portion of the power area.

B. Regional Power Liaison

Representative

1. Upon notification by the Area Director or the declaration of a national emergency, report to the assigned FEMA Regional EOC as soon as possible.

2. Represent the EEPA Headquarters and the Area Director at the FEMA Regional office on al electric power matters, including requests from the Area Director for adjudication of conflicting requests for essential power supply, materials.

3. Refer to the appropriate Area Director all electric power problems as they occur.

C. State Power Liaison Representative

1. Report to the State EOC upon notification from the Area Director or declaration of a national emergency.

2. Serve as liaison at the state EOC on electric power matters, including the allocation of available olestrie supply to essent.ial. uses and load curtailment within the state. 
3. Serve as the point of contact at the State EOC for the electric utilities and the Area Director.

4. Refer to the appropriate Area Director electric power problems that have been raised at the state level.

5. In accordance with priorities and allocations established by the Area Director, serve as liaison to utilities within the state regarding the needs for manpower, equipment, and materials from other utilities.

6. Arrange for required supporting resources for electric utilities from the state government (e.g., removing highway obstructions to allow access to damaged facilities).

D. Major Utility Representative

1. Report to the company EoC upon notification from the Area Director or the State Power Liaison, or upon the declaration of a national emergency.

2. Serve as liaison to local government officials on electric power matters.

3. Keep local government offinials informed on the availability of electric power, advise on the allocation of available supply to essential uses and on load curtailment procedures.

4. Refer to the appropriate utility local government requests for restoration of service with the order of priority indicated by local government officials. Unresolvable conflicting requirements should be relayed to the state Power Liaison for adjudication at that level.

5. Refer electric power problems to the State Power Liaison or Area Director as requested by the utility concerned.

6. Execute orders from the Area Director regarding allocation of power, manpower, materials, and other utility resources.

\section{E. State and Local Governments}

1. Consult on all electric power matters with the appropriate EEPA Representatives. Inform utilities or the Area Director of essential needs through the Power Liaison Representatives.

2. The State Electric Power Agency issues curtailment orders when the Area Director cannot be reached. such orders could be for all or any part of the state but should not extend beyond state borders.
3. If, after curtailment, power is not available to meet all essential needs, determine the order of priority among users within their respective jurisdictions. If the conflict affects users in another jurisdiction, refer the matter to the next higher level of government. A local government would refer it to the State; a State government to the Area Director for decision or, in the case of an appeal, to the FEMA Regional Director for adjudication.

4. Local governments issue curtailment orders when the state government or the EEPA Area Director cannot be reached, and they enforce curtailment orders issued by higher authority.

3. Assist in emergency restoration and repair of essential facilities.

6. Permit electric utilities to retain for their use wholly-owned communication facilities and those leased for their exclusive use, subject to Federal regulation.

7. Forward damage reports on electric power facilities to the next higher level of government.

8. Upon activation by the state or local government of its emergency resource management organization, or other organization performing emergency electric power resource functions, direct the officials of such organizations to establish contact with their EEPA counterparts as soon as possible.

F. Electric Utilities

1. Comply with requests from local, State, and Federal agencies for supply of electric power to essential uses.

2. Activate power liaison personnel at local and state governments.

3. Invoke mutual aid agreements, as necessary.

4. Request needed equipment and manpower from other utilities. Actual transfer is subject to approval of the Area Director.

5. Report damage, total remaining capability, and total demand to the Area Director.

6. If electric service cannot be supplied safely to an area, the utility will disconnect all power supply to the area. 
7. If power is not available to meet demands, request the Area Director to order curtailment of non-essential uses in the area, and at the same time notify and request the affected government, through the Power Liaison, to enforce the curtailment.

8. If, after curtailment, the supply of power is not sufficient to meet essential needs, obtain a decision on priority of use and proceed accordingly. Conflicts should be submitted for resolution as follows:

a. If the conflict is within the jurisdiction of a single local government, refer to the local government, through the Major Utility Representative, for a decision.

b. It the conflict involves two or more jurisdictions within a State, obtain a decision from the State government. The request may be made either through the state Power Llalson or through lise Arta Director.

c. If the conflict crosses state lines, refer to the Area Director for a decision.

IV. Guidance on Priorities and Curtailment

The policy of the Federal Government on use of resources during a national emergency is stated in Defense Mobilization order 4, "Guidance on Priority Use of Resources in Immediate Postattack Period." A copy of this order is included in Appendix I of this Handbook.

DMO 4 states: "In an immediate postattack period all decisions regarding the use of resources will be directed to the objective of national survival and recovery. In order to achieve this objective, postattack resources will be assigned to activities concerned with the maintenance and saving of lives, immediate military defense and retaliatory operations, and economic activities essential to continue survival and recovery." DMO 4 further states that the guidance it provides,"... is designed to achieve a degree of national equity in the use of resources and to assign and conserve resources effectively in the immediate postattack period. Until more specific instructions are available, these are the general guidelines within which managerial judgement and common sense must be used to achieve national objectives under widely differing emergency conditions." The Order lists those activities which are to be accorded priority.
The guidelines set forth in DMO 4 pertain to electric power as well as to other resources. This Appendix is intended to supplement, and in no way modify, the guidance given in DMO 4 . If any provision should appear to be inconsistent with the guidance in DMO 4, the latter shall govern.

\section{A. Priority of Electric Power Use}

In the event of nuclear attack, electric power that is available for use must be carefully conserved regardless whether any power facilities have been damaged. Electric power use must be restricted to essential facilities, essential local users, and the minimum needs of individual consumers until the continuing supply can be assessed and the supply that will be available for less essential needs can be determined. If the available power supply is inadequate to serve all these needs, the local or state government determines the order of priority. These items are defined as follows:

\section{Essential Facilities are:}

a. Military establishments engaged in immediate retaliatory or defense operations

b. Electric power, gas, and water utility systems

c. Industrial plants producing or processing essential items

d. Major wholesale establishments storing or

distributing exsential ilifans

e. Transportation and communications systems providing essential services

2. Essential Local Users are:

a. Civilian organizations engaged in essential civil defense activities including persons, equipment, and facilities providing essential survival care and services to people

b. Military organizations engaged in essential military activities

c. Farmers producing essential food and workers employed in essential facilities or local establishments providing essential items and services to people

d. Individual consumers requiring immediate power supply for individual or family survival 
3. Individual Consumers are consumers not included in Essential Local Users or Essential Facilities. These Individual Consumers obtain electric power for authorized uses from local utilities subject to curtailment on use issued by the EEPA Director, Governor or local Government.

B. Curtailment

Curtailment of electric power use for less essential needs may consist of any of a number of specific types of service or may specify certain hours of usage. For uniformity it is suggested that curtailment normally be handled in the following six steps. Modification of these steps may be desirable to fit local conditions. (See page E-10, Sample Curtailment Order.) Enforcement will be by state and local Government. The public will be informed and instructed through any communication media available.

\section{Step I--Discontinue}

a. All exterior advertising, decorative, and flood lighting

b. All show window lighting

c. All interior display and showcase lighting

conditioning

$$
\text { d. All comfort air }
$$

e. The use of electric ovens and broilers in home cooking and reduce use of electricity for other home cooking to an absolute minimum

f. The use of all residential electrical appliances except refrigerators, ranges (top only), and television or radio receivers

g. Nonresidential cooking and baking on electrical equipment except for essential staple foods, and reduce nondomestic use of electricity for all cooking and baking to an absolute minimum.

\section{Step II-Reduce}

a. Elevator service to an absolute minimum

b. Public lighting to the absolute minimum essential for safety

c. Thermostat setting for comfort heating, utilizing electricity to a maximum of $65^{\circ}$ daytime and $50^{\circ}$ nighttime temperature

d. The use of hot water heated by electricity to minimum requirements e. General illumination of $50 \%$ in all commercial and residential establishments

f. Electric transportation facility heating by $50 \%$

g. The use of radio and television receivers to a minimum necessary to receive civil defense information and instructions

3. Step III--Discontinue the Use of Electricity Except for Preservation of Equipment

amusement

a. In all places of

b. In nonessential public places (such as museums, galleries, etc.)

c. In schools other than those with pupils attending pursuant to requirements of the compulsory Education Law, and institutions of higher learning

4. Step IV--Discontinue the Use of Electricity Except that Necessary for Preservation of Equipment

a. In all commercial wholesale and retail establishments except those engaged in the distribution of controlled-temperature storage of goods, fuel, medical supplies and medicines

b. In all industrial establishments not engaged in the manufacture, processing, or controlled-temperature storage of staple foods, medicines, and medical supplies or directly engaged in defense manufacture

c. In all office buildings not engaged in communications, utilities, police, fire, health, water supply, public works, welfare, and transportation services

\section{Step V--Discontinue Defense} Industrial Use of Electricity

All industrial establishments directly engaged in defense manufacture, except those engaged in the manufacturing, processing, controlled-temperature storage and distribution of staple foods, fuel and medical supplies, shall be ordered to discontinue the use of electric service.

6. Step VI--Discontinue use of electricity to preferred essential services (essential local users and essential facilities) as defined in I above. 
SAMPLE CURTAILMENT ORDER

To:

Electric Utility(s)

EEPA State Electric Power Liaioon Representative.

From: $\quad$ EEPA Area Power Director

Subject: Curtailment of Electric Power

Electric power supply in the area described below is presently inadequate to meet the demands of all consumers.

In order for electric power to be availablc for the more essential. needs, it is hereby directed that electric power be denied for all uses listed in Curtailment Step(s)

This order becomes effective on the date indicated and continues until further notice. It applies to all consumers in the area affected.

ARE $\Lambda$ POWER DIRECTOR
EEPA AREA

Areas affectod by this order -

Effeotive Date of Order

CC:- State(s) Governor

The above is an example of an initial order. It would be modified to suit any curtailment increase, decrease, or cancellation. 


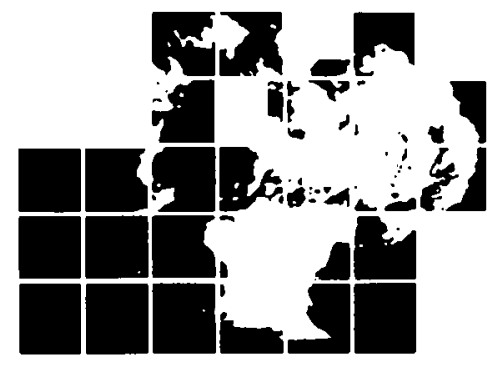

\section{Claimancy \& Restoration}

(This Appendix is being developed by an EEPA Task Group)

The Emergency Electric Power Administration is working with elements of the Federal Emergency Management Agency (FEMA), Department of Commerce, and the Department of Transportation in developing this section.

\section{CLAIMANCY FUNCTIONS}

- Determine Requirements

- Submit Needs

- Allocate Available Resources 
Power Supply in a

National Emergency
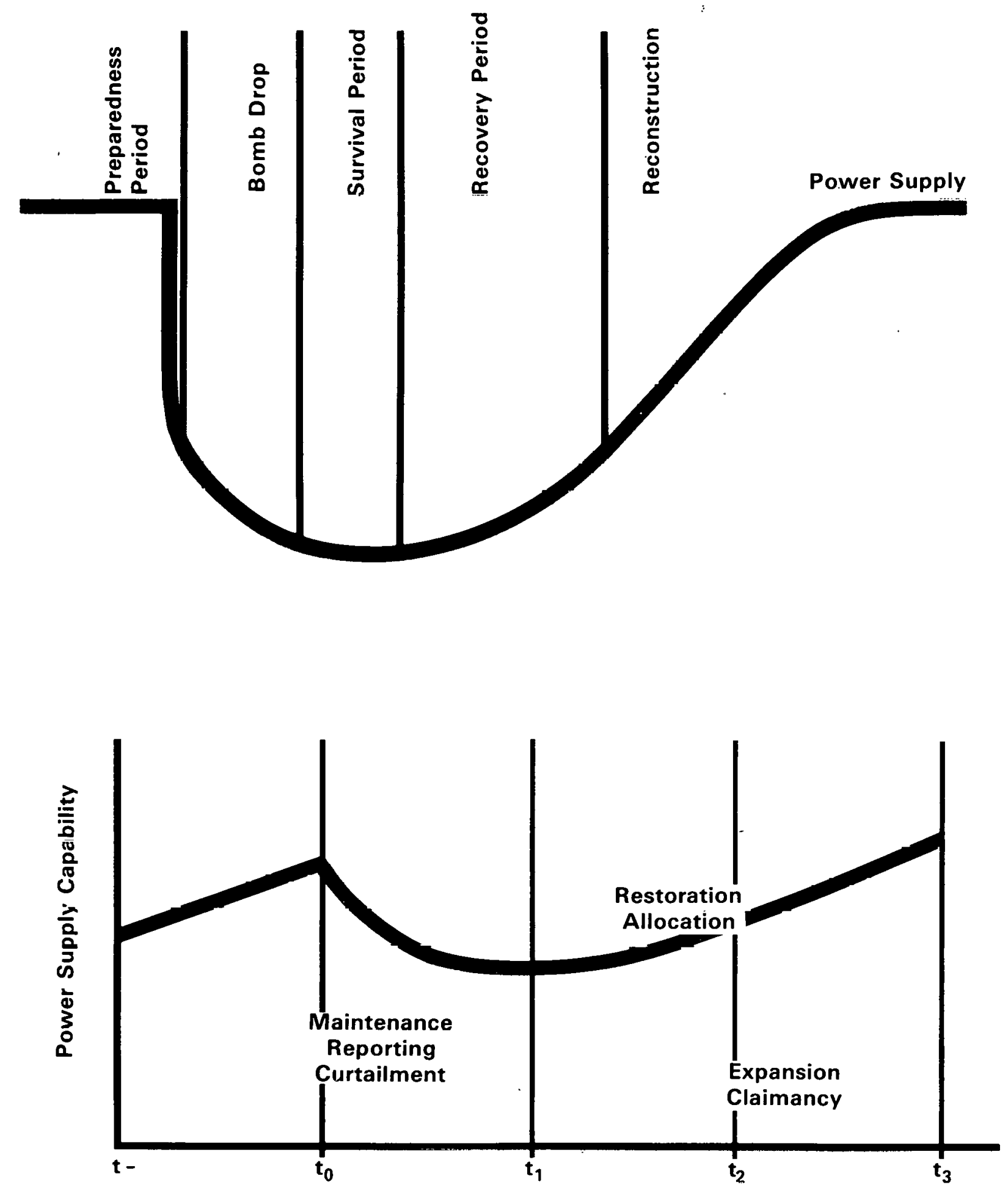

Changing Role of DEPA in Resource Management 


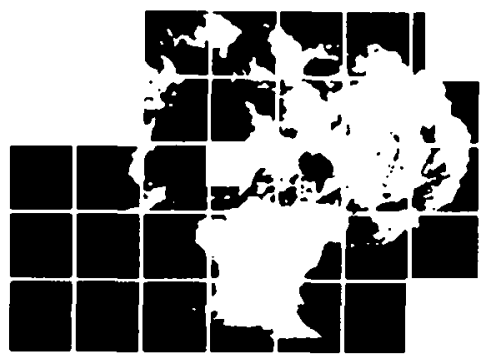

\section{Communications \& Warning}

(This Appendix is being developed by an EEPA Task Group)

A request has been sent from EEPA Headquarters to the National Electric Reliability Council (NERC) Office requesting assistance in this area. EEPA has drafted a concept paper which will be used to initiate a "pilot" project utilizing conventional communication devices or satellites. It is anticipated that with NERC's cooperation and technical assistance, a viable emergency communications system can be developed from these alternatives. A proposed communications connectivity matrix is included for review. Any network that is devised will of course be established in accordance with the National Communications System (NCS).

\section{Communication and Warning}

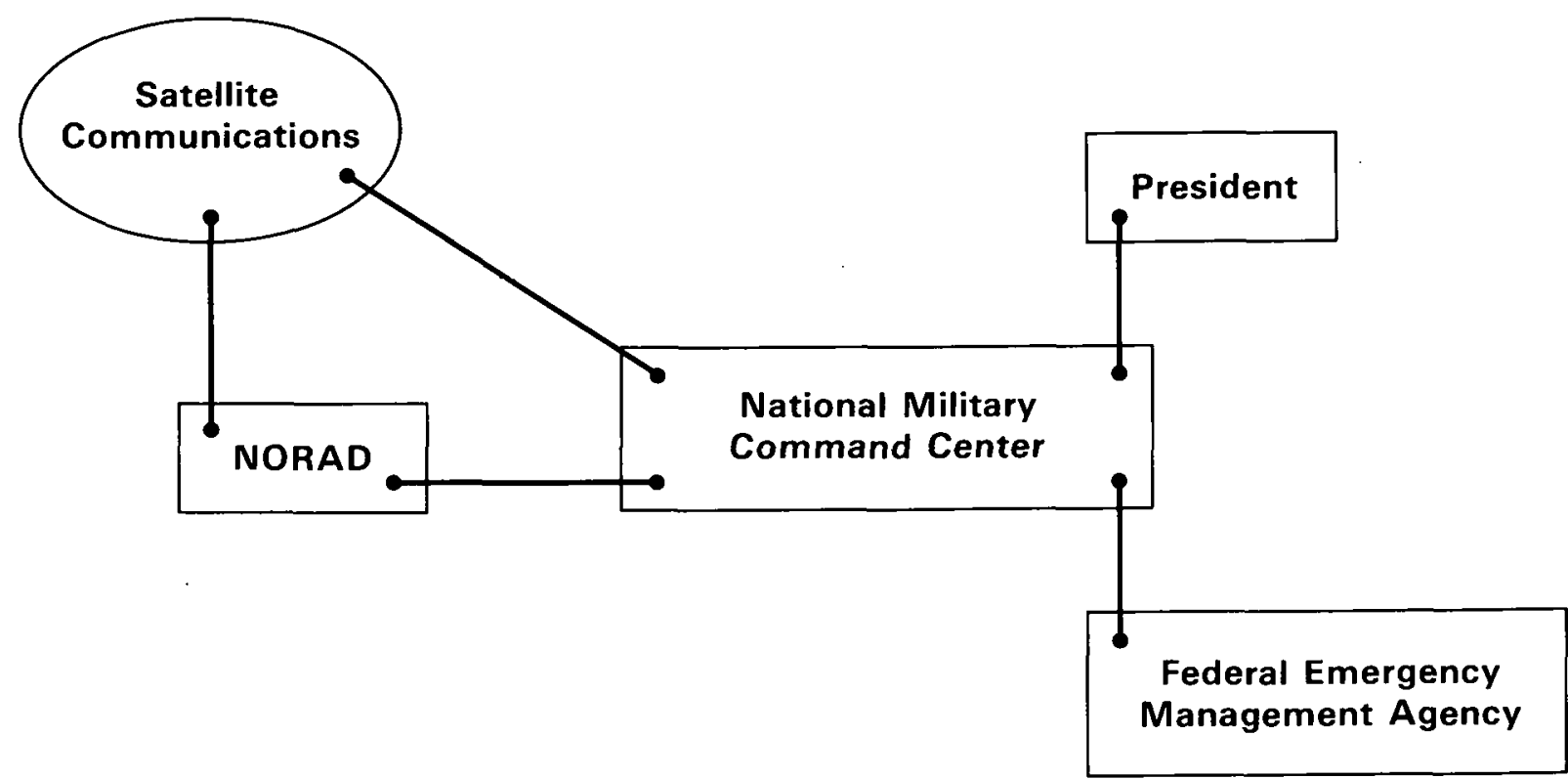

Land Line and Satellite Communications Links 


\section{EEPA}

Communications

Connectivity

Model

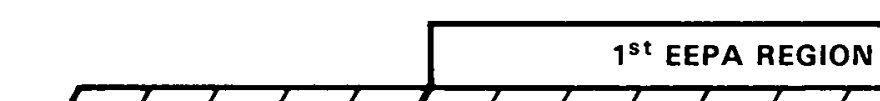

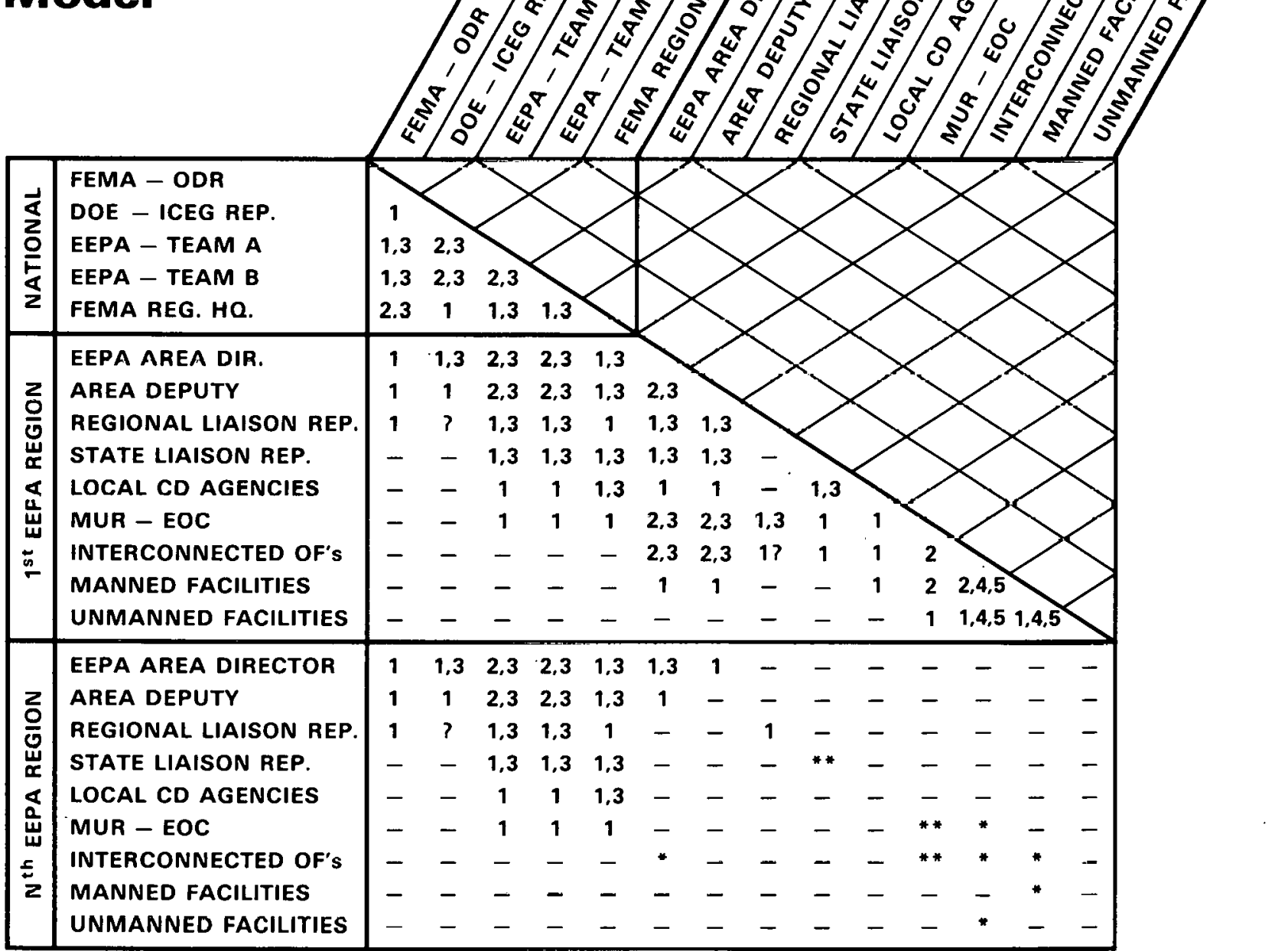

\begin{tabular}{|c|l|l|}
\hline CAT. & \multicolumn{1}{|c|}{ SERVICE } & \multicolumn{1}{|c|}{ PURPOSE } \\
\hline 1. & VOICE - INTERMITTENT & REPORT - COORDINATE \\
2. & VOICE - FULL PERIOD & WARNING/CONTROL/COORDIN. \\
3. & RECORD - TTY OR FACSIMILE & REPORT - COORDINATE \\
4. & TELEMETRY & SYS. CONTROL - DIAGNOSTICS \\
6. & DATA LINK & SYS. CONTROL - MGMT. \\
\hline
\end{tabular}

"CAT. 2 IF INTERCONNECTED ACROSS EEPA REGION BOUNDARIES.

"*CAT. 1 IF CONTIGUOUS STATES AND CONNECTED UTILITIES. 


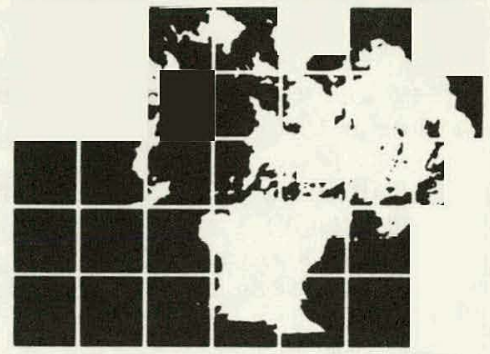

\section{Effects of Nuclear Weapons}

This Appendix briefly summarizes several effects of nuclear weapons that are of concern to engineers responsible for the restoration of electrical power following a nuclear attack.* For simplicity, the effects of only a single explosion are considered. The effects of multiple explosions, which would be the case in many scenarins of interest, are much more complex and uncertain and are seldom treated. Reference 1 provides a limited discussion of such multiburst effects, including quantitative estimates of the phenomena.

In the main, the effects of nuclear explosions involve:

- Blast and shock which can produce direct physical damage to buildings, equipment, power distribution systems, and other physical plant assets out to a range of several miles from a megaton burst; can also lead to secondary damage by fires produced by broken gas mains, etc., at even greater range.

- Ejecta and debris from cratering explosions which can cause physical damage to a range of about a mile from a megaton surface burst. Radioactive fallout can impose potentially lethal working conditions hundreds of miles downwind for days and possibly weeks following the explosion.

* This Appendix draws heavily upon The Effects of Nuclear War, published by the Office of Technology Assessment of the Congress of the United States, Library of Congress Catalog Card Number 79-600080, U.S. Government Printing Ofice, Washington, D.C. 20402. Other key references are given in the Bibliography.
- Thermal radiation which may cause damage directly or indirectly as a result of fires out to a range of several miles from a megaton explosion.

- Electromagnetic pulse (EMP) which can cause damage to electronics, especially modern electronics, at very great ranges from nuclear explosions. For example, a single highaltitude megaton burst (at say 100 miles) will expose over one-third of the U.S. to fields in excess of $50 \mathrm{k}$ volts $/ \mathrm{m}$. Such fields can induce large damaging currents in power lines, telephone lines and other interconnecting links which in turn can cause damage at great ranges (100's of miles) from ground zero.

- Direct nuclear radiation - not particularly relevant for most electric power systems since radiation levels required to cause damage occur at ranges from high yield bursts where blast, shock and thermal effects would be expected to cause severe damage.

The distribution of the bomb's energy among these effects depends on its size and on the details of its design, but a general description is possible.

\section{Blast and Shock}

Most damage to cities from large weapons comes from the explosive blast. The blast directs air away from the site of the explosion, producing sudden changes in air pressure (called static overpressure) that can move them suddenly or knock them down. In general, large 
buildings are destroyed by the overpressure, while people and objects such as trees and utility poles are destroyed by the wind.

For example, consider the effects of a 1-megaton (Mt) air burst on things 4 miles $(6 \mathrm{~km})$ away. The overpressure will be in excess of 5 pounds per square inch (psi), which will exert a force of more than 180 tons on the wall of a typical two-story house (see Figure 1). At the same place there would be a hurricane force wind of $160 \mathrm{mph}(255 \mathrm{~km})$; while 5 psi is not enough to crush a man, a wind of $180 \mathrm{mph}$ would create fatal collisions between people and nearby objects. Such effects are thought to cause damage to electric power plants that would require on the order of a year to repair in a peacetime economy. Power lines and other above surface compuneuls of the clootrio power network would also likely suffer damage within this radius (see Figure 2).
The magnitude of the blast effect (generally measured in pounds per square inch) diminishes with distance from the center of the explosion. It is related in a more complicated way to the height of the burst above ground level. For any given distance from the center of the explosion, there is an optimum burst height that will produce the greatest overpressure, and the greater the distance the greater the optimum burst height. As a result, a burst on the surface produces the greatest overpressure at very close ranges (which is why surface bursts are used to attack very hard, very small targets such as missile silos or possibly nuclear powerplants), but less overpressure than an air burst at somewhat longer ranges. Raising the height of the burst reduces the overpressure directly under the bomb, but can witen the area at which a given smaller overpressure is produced. 'lnus, dil attack on factories with a 1-Mt weapon mighl use an air burst at an altitude of

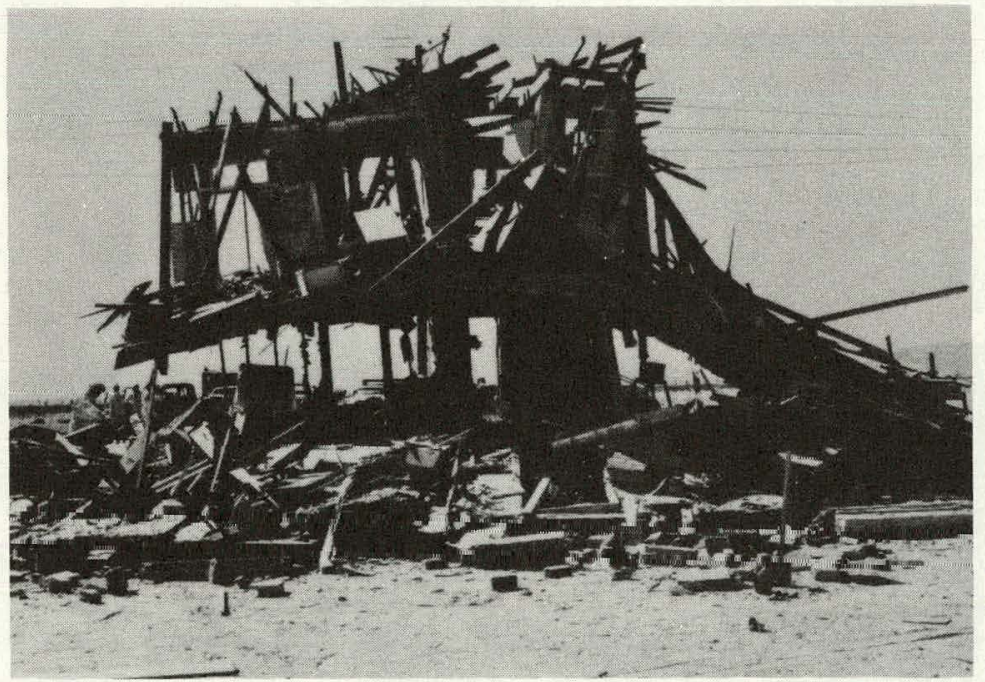

Unreinforced brick house after a nuclear explosion

(1.7 psi peak overpressure)

Unreinforced brick house after a nuclear explosion (5 psi peak overpressure)

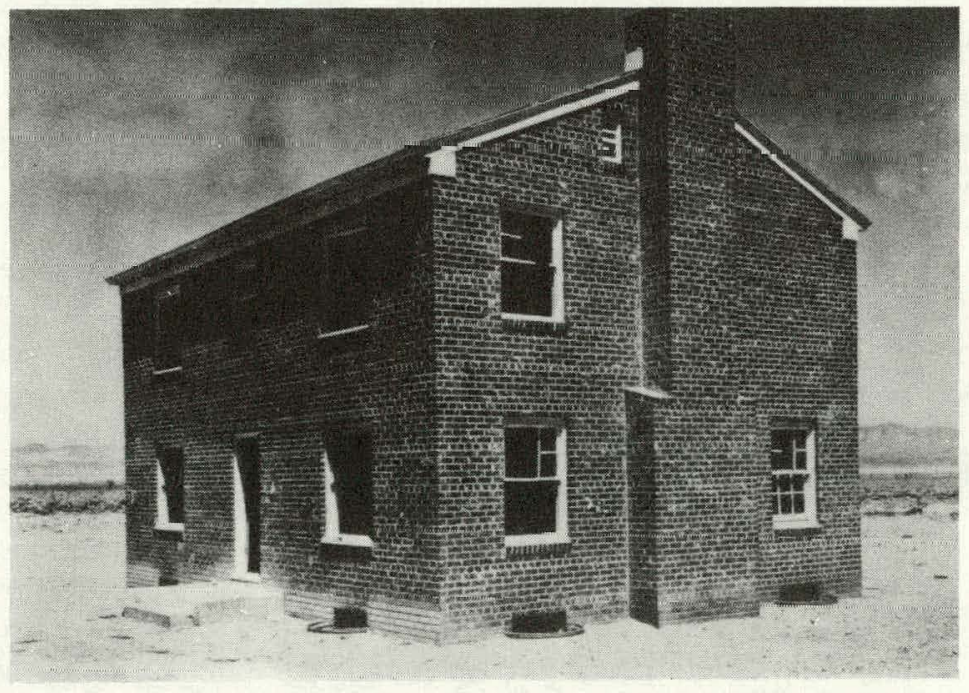

Courtesy of Defense Nuclear Agency

Figure 1 
8,000 feet $(2,400 \mathrm{~m})$, which would maximize the area (about $28 \mathrm{mi}^{2}(7,200$ hectares) that would receive $10 \mathrm{psi}$ or more of overpressure.

Table 1 shows the ranges of overpressures and effects from such a blast and Figures 3 and 4 illustrate the overpressure range from hypothesized 1 and 25 megaton airbursts over Detroit.

When a nuclear weapon is detonated on or near the surface of the earth, the blast digs out a large crater. Some of the material that used to be in the crater is deposited on the rim of the crater; the rest is carried up into the air and returns to earth as fallout. An explosion that is farther above the earth's surface than the radius of the fireball does not dig a crater and produces negligible immediate fallout.

For the most part, blast kills people by indirect means rather than by direct pressure. While a human body can withstand up to psi of simple overpressure,

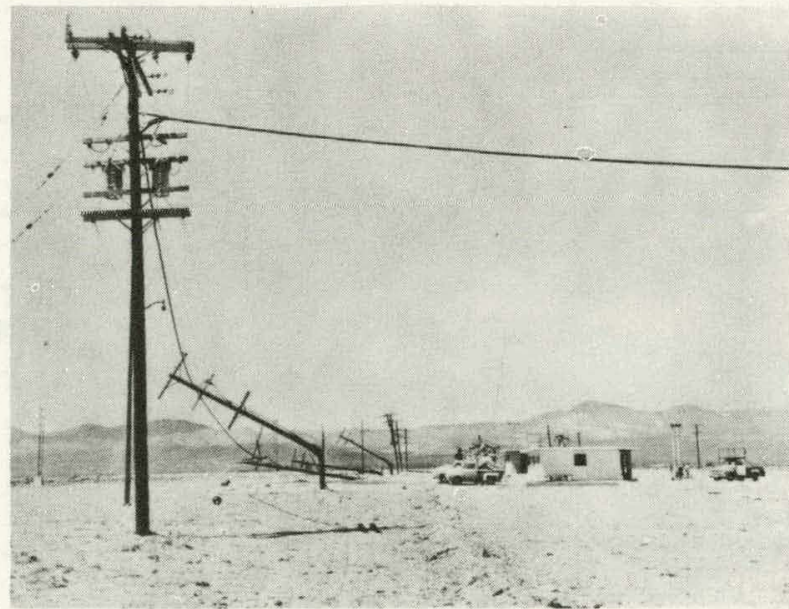

Figure 2 - Collapse of utility poles on line ( 5 psi peak overpressure, 0.6 psi dynamic pressure from 30-kiloton explosion), Nevada Test Site

Table 1 - Blast Effects of a 1-Mt Explosion 8,000 ft Above the Earth's Surface

\begin{tabular}{|c|c|c|c|c|}
\hline $\begin{array}{l}\text { Distance fro } \\
\text { (stat.miles) }\end{array}$ & $\frac{\text { ground zero }}{\text { (kilometers) }}$ & $\begin{array}{c}\text { Peak } \\
\text { overpressure }\end{array}$ & $\begin{array}{l}\text { Peak wind } \\
\text { velocity (mph) }\end{array}$ & Typical blast effects \\
\hline .8 & 1.3 & $20 \mathrm{psi}$ & 470 & $\begin{array}{l}\text { Reinforced concrete structures } \\
\text { are levelled. }\end{array}$ \\
\hline 3.0 & 4.8 & $10 \mathrm{psi}$ & 290 & $\begin{array}{l}\text { Must factorles and commercial } \\
\text { buildings are collapsed. Small } \\
\text { wood frame and brick residences } \\
\text { destroyed and distributed } \\
\text { as debris. }\end{array}$ \\
\hline 4.4 & 7.0 & $5 \mathrm{psi}$ & 160 & $\begin{array}{l}\text { Lightly constructed commercial } \\
\text { buldings and typical residences } \\
\text { are destroyed; heavier construc- } \\
\text { tion is severely damaged. Power } \\
\text { lines and electrical power } \\
\text { plants heavily damaged. }\end{array}$ \\
\hline 5.9 & 9.5 & $3 \mathrm{psi}$ & 95 & $\begin{array}{l}\text { Walls of typical steel-frame } \\
\text { buildings are blown away; severe } \\
\text { damage to residences. Winds } \\
\text { sufficient to kill people in the } \\
\text { open. }\end{array}$ \\
\hline
\end{tabular}

$\begin{array}{llll}11.6 & 18.6 & 1 \mathrm{psi} & 35\end{array}$

Damage to structures; people endangered by flying glass and debris.

the winds associated with as little as 2 to 3 psi could be expected to blow people out of typical modern office buildings. Most blast deaths are expected to result from the collapse of occupied buildings, from people being blown into objects, or from buildings or smaller objects being blown onto or into people. Clearly, then, it is impossible to calculate with any precision how many people would be killed by a given blast--the effects would vary from building to building.

\section{Direct Nuclear Radiation}

Nuclear weapons inflict ionizing radiation on people, animals, and plants in two differnt ways. Direct radiation occurs at the time of the explosion; it can be very intense, but its range is limited. Fallout radiation is received from particles that are made radioactive by the effects of the explosion, and subsequently distributed at varying distances from the site of the blast. 
Appendix $\mathrm{H}$

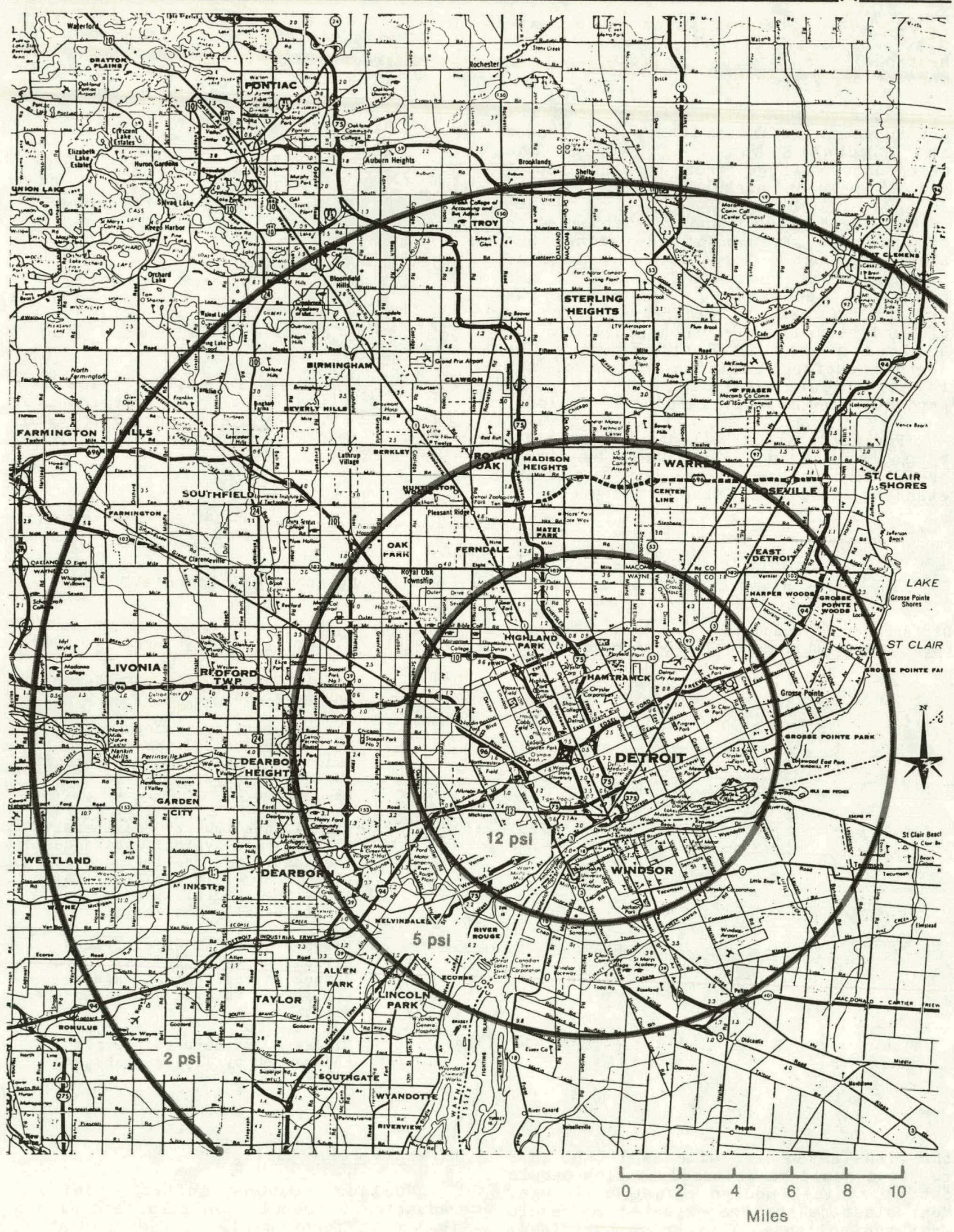

Figure 3 


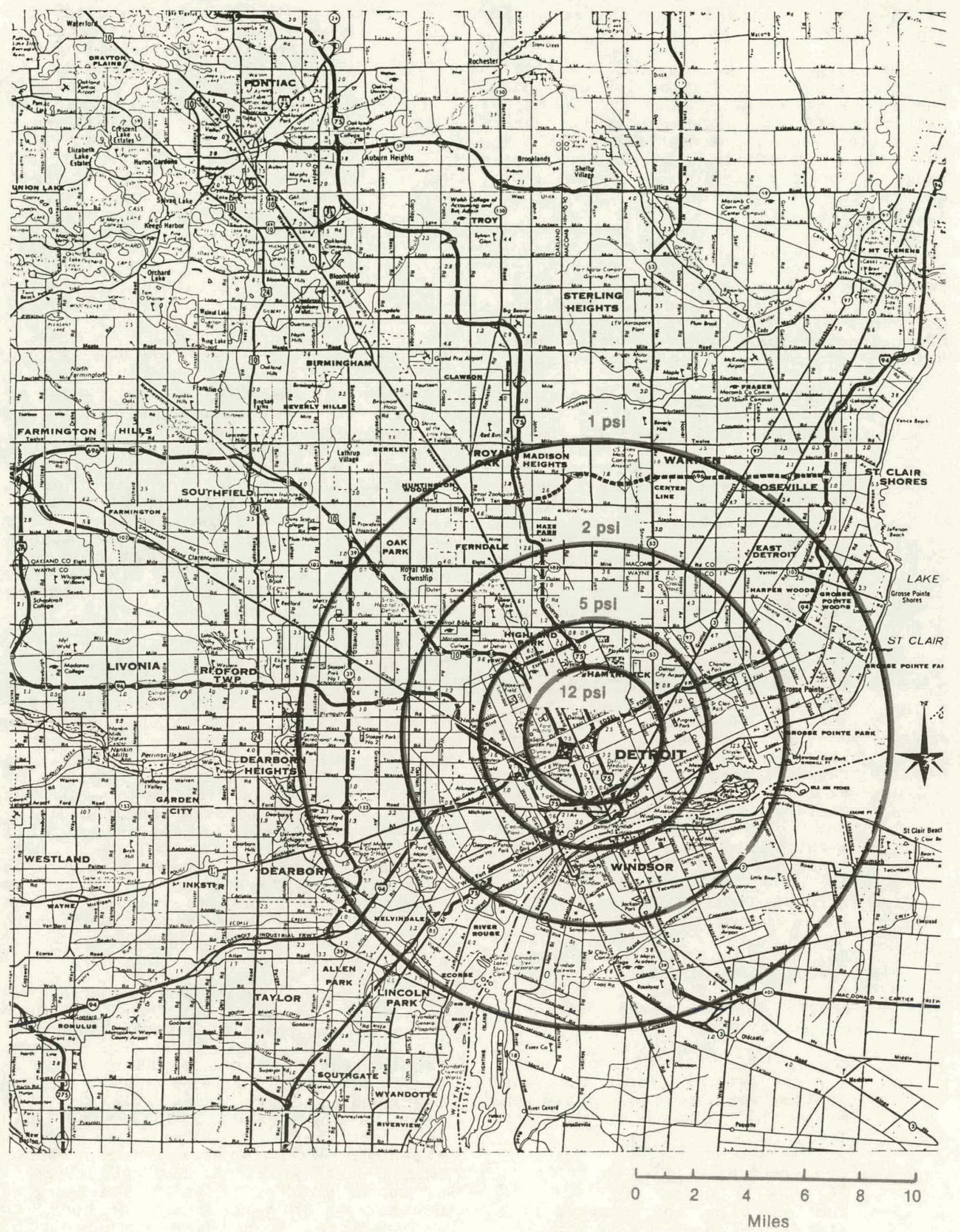

Figure 4 
Fallout is discussed in a subsequent section.

For large nuclear weapons, the range of intense direct radiation is less than the range of lethal blast and thermal radiation effects. However, in the case of smaller weapons, direct radiation may be the lethal effect with the greatest range. Direct radiation did substantial damage to the residents of Hiroshima and Nagasaki.

Human response to ionizing radiation is subject to great scientific uncertainty and intense controversy. It seems likely that even small doses of radiation do some harm. To understand the effects of nuclear weapons, one must distinguish between short- and long-term effects:

- Short Term Effects. A dose of 600 rem within a short period of time ( 6 to 7 days) has a 90 percent chance of creating a fatal illness, with death occurring within a f'ew weeks. (A rem nr "roentgen-equivalentman" is a measure of biological damage: a "rad" is a measure of radiation energy absorbed; a roentgen is a measure of radiation energy; for our purposes it may be assumed that 100 roentgens produce 100 rads and 100 rem.) The precise shape of the curve showing the death rate as a function of radiation dose is not known in the region between 300 and 600 rem, but a dose of 450 rem within a short time is estimated to create a fatal illness in half the people exposed to it; the other half would get very sick, but would recover. A dose of 300 reell might kill about 10 percent of those exposd. A duse of 200 to 450 rem will cause a severe illness from which most people would rccover; however, this illness would render people highly susceptible to other diseases or infections. A dose of 50 to 200 rem will cause nausea and lower resistance to other diseases, but medical treatment is not required. A dose below 50 rem will not cause any short-term effects that the victim will notice, but will nevertheless do long-term damage.

- Long-Term Effects. The effects of smaller doses of radiation are long term, and measured in a statistical way. A dose of 50 rem generally produces no short-term effects; however, if a large population were exposed to 50 rems, somewhere between 0.4 and 2.5 percent of them would be expected to contract fatal cancer (after some years) as a result. There would also be serious genetic effects for some fraction of those exposed. Lower doses produce lower effects. There is a scientific controversy about whether any dose of radiation, however, small, is really safe. The extent of the long-term effects that a nulcear attack might produce are very uncertain. It should be clearly understood, however, that a large nuclear war would expose the survivors, however well sheltered, to levels of radiation far greater than the U.S. Government considers safe.

Thermal Radiation

Approximately 35 percent of the energy from a nuclear explosion is ar intense burst of thermal radiation, i.e., heat. I'he effects are roughly analogous to the effect of a 2-second flash from an enormous sunlamp. Since the thermal radiation travels at the speed of light (actualiy a bil slower, since it is deflected by particles in the atmosphere), the flash of light and heat precedes the blast wave by several seconds, just as lightning is seen before the thunder is heard.

The visible light will produce "flashblindness" in people who are looking in the direction of the explosion. Flashblindness can last for several minutes, after which recovery is total. A 1-Mt explosion could cause flashblindness at distances as great as 13 miles $(21 \mathrm{~km})$ on a clear day, or 53 miles $(85 \mathrm{~km})$ on a clear night. If the flash is focused through the lens of the eye, d permanent rotinal burn will result. At Hiroshima and Nagasaki, there were many cases of flashlindness, but only one case of retinal burn, among the survivors. On the other hand, anyone flashblinded while driving a car could easily cause permanent injury to himself and to others.

Skin burns result from higher intensities of light, and therfore take place closer to the point of explosion. A 1-Mt explosion can cause first-degree burns (equivaleril lu a bad sunburn) at distances of about 7 miles $(11 \mathrm{~km})$, seconddegree burns (producing blisters that lead to infection if untreated, and permanent scars) at distances of about 6 miles $(10 \mathrm{~km})$, and third-degree burns (which destroy skin tissue) at distances of up to 5 miles $(8 \mathrm{~km})$. Third-degree burns over 24 percent of the body, or second-degree burns over 30 percent of the body, will result in serious shock, and will probably prove fatal unless prompt, specialized medical care is available. The entire United States has facilities to treat 1,000 or 2,000 severe burn cases; a singe nuclear weapon could produce more than 10,000 . 
The distance at which burns are dangerous depends heavily on weather conditions. Extensive moisture or a high concentration of particles in the air (smog) absorbs thermal radiation. Thermal radiation behaves like sunlight, so objects create shadows behind which the thermal radiation is indirect (reflected) and less intense. Some conditions, such as ice on the ground or low white clouds over clean air, can increase the range of dangerous thermal radiation.

\section{Fires}

The thermal radiation from a nuclear explosion can directly ignite kindling materials. In general, ignitible materials outside the house, such as leaves or newspapers, are not surrounded by enough combustible material to generate a self-sustaining fire. Fires more likely to spread are those caused by thermal radiation passing through windows to ignite beds and overstuffed furniture inside houses. A rather substantial amount of combustible material must burn vigorously for 10 to 20 minutes before the room, or whole house, becomes inflamed. The blast wave, which arrives after most thermal energy has been expended, will have some extinguishing effect on the fires. However, studies and tests of this effect have been very contradictory, so the extent to which blast can be counted on to extinguish fire starts remains quite uncertain.

Another possible source of fires, which might be more damaging in urban areas, is indirect. Blast damage to stores, water heaters, furnances, electrical circuits, or gas lines would ignite fires where fuel is plentiful.

Although there are very large uncertainties, significant fire damage from bursts in urban areas might exist out to the 5-10 psi peak overpressure range, i.e., several miles from ground zero of a megaton burst.

It is possible that individual fires, whether caused by thermal radiation or by blast damage to utilities, furnaces, etc., would coalesce into a mass fire that would consume all structures over a large area. This possibility has been intensely studied, but there remains no basis for estimating its probability. Mass fires could be of two kinds: a "firestorm," in which violent inrushing winds create extremely high temperatures but prevent the fire from spreading radially outwards, and a "conflagration," in which a fire spreads along a front. Hamburg, Tokyo, and Hiroshima experienced firestorms in world War II; the Great Chicago Fire and the San Francisco. Earthquake Fire were conflagrations. A firestorm is likely to kill a high proportion of the people in the area of the fire, through heat and through asphyxiation of those in shelters. A conflagration spreads slowly enough so that people in its path can escape, though a conflagration caused by a nuclear attack might take a heavy toll of those too injured to walk. Some believe that firestorms in modern U.S. cities are unlikely because the density of flammable materials ("fuel loading") is too low-the ignition of a firestorm is thought to require a fuel loading of at least $8 \mathrm{lb} / \mathrm{ft}^{2}$ (Hamburg had 32), compared to fuel loading of $2 \mathrm{lbs} / \mathrm{ft}^{2}$ in a neighborhood of two-story brick rowhouses. The likelihood of a conflagration depends on the geography of the area, the speed and direction of the wind, and details of building construction. Another variable is whether people and equipment are available to fight fires before they can coalesce and spread.

\section{Electromagnetic Pulse}

Electromagnetic pulse (EMP) i.s an electromagnetic wave similar to radio waves, which results from secondary reactions occurring when the nuclear gamma radiation is absorbed in the air or ground. It differs from the usual radio waves in two important ways. First, it creates much higher electric field strengths. Whereas a radio signal might produce a thousandth of a volt or less in a receiving antenna, an EMP pulse might produce thousands of volts. Secondly, it is a single pulse of energy that disappears completely in a small fraction of a second. In this sense, it is rather similar to the electrical signal from lightning, but the rise in voltage is typically a hundred times faster. This means that most equipment designed to protect electrical facilities from lightning works too slowly to be effective against EMP.

The strength of an EMP pulse is measured in volts per meter $(\mathrm{v} / \mathrm{m})$, and is an indication of the voltage that would be produced in an exposed antenna. A nuclear weapon burst on the surface will typically produce an EMP of tens of thousands of $\mathrm{v} / \mathrm{m}$ at short distances (the 10-psi range) and thousands of $v / m$ at longer distances (1-psi range). Air bursts produce less EMP, but high-altitude bursts (above 19 miles ( $21 \mathrm{~km}$ ), produce very strong EMP, with ranges of hundreds or thousands of miles. An attacker might detonate a few weapons at such altitudes in an effort to destroy or damage the communications and electric power systems of the victim. For example, Figure 5 illustrates the coverage of $25-50 \mathrm{kv} / \mathrm{m}$ produced by megaton weapons at 100 and $400 \mathrm{~km}$ height of burst.

A recently uncovered effect from high altitude nuclear detonations is magneto-hydrodynamic EMP (MHD EMP). It is slowly being understood and quantified so much remains uncertain. It is caused by the interaction of the hot high altitude "fireball" plasma with the 


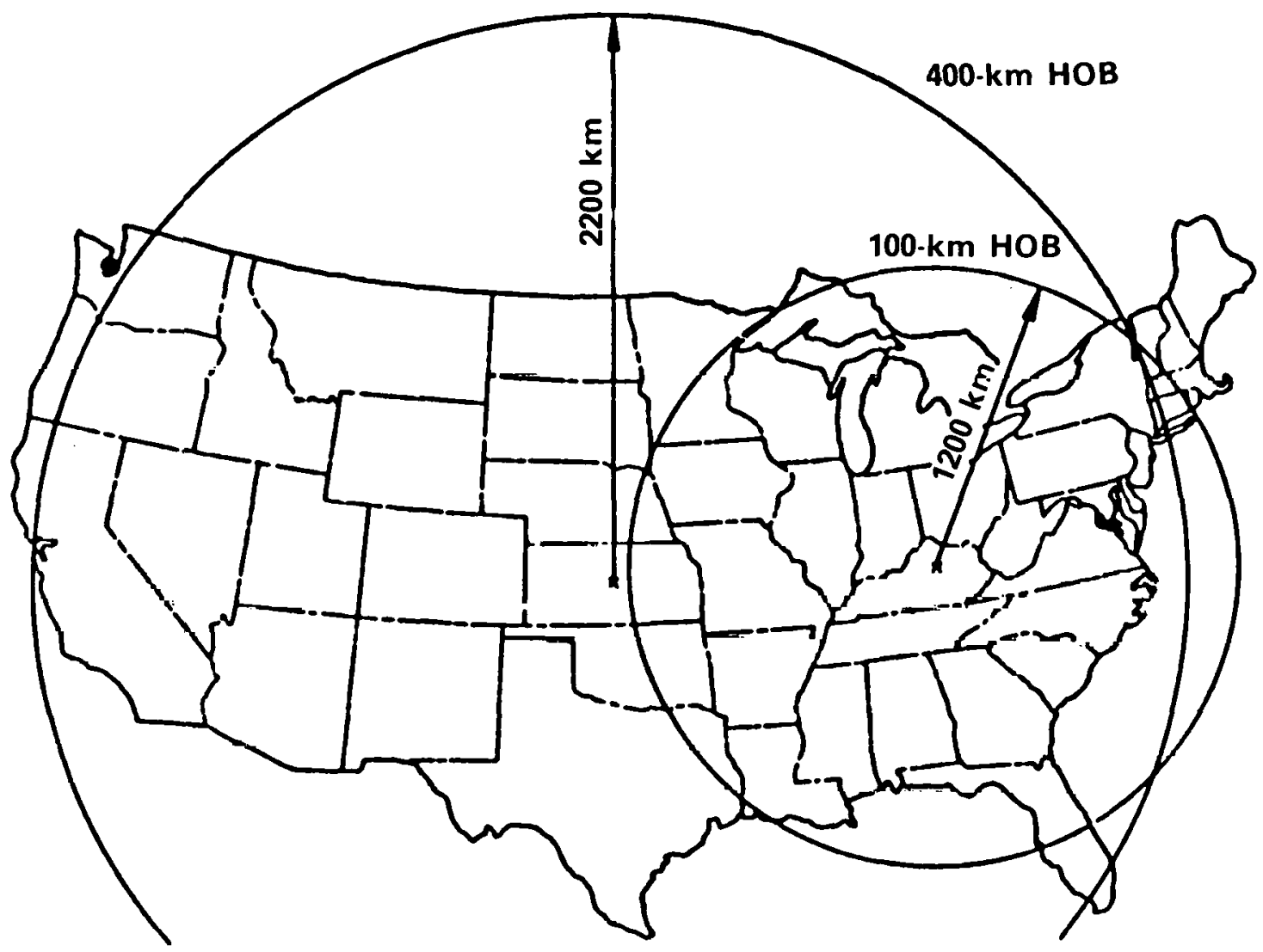

Fig. 5 Typical 25-50 kv/m Area Coverage of EMP for Both a 100-Kilometer and a 400 Kilometer Height of Burst (HOB).

earth's magnetic field causing ionospheric currents to flow and producing perturbations in the earth's magnetic field. This changing field in the presence of the conducting earth acts as a generator producing earth currents and electric potential differences across the earth's surface.

The MHD EMP effect is proportional to the amount of hot plasma produced and its efficiency in interacting with the magnetic field. Bursts in the $200-250 \mathrm{~km}$ altitude range are probably most efficient but effects can be produced by bursts from about 150 to $500 \mathrm{~km}$. The frequency of the fields produced are $.5-.001 \mathrm{~Hz}$ or effectively D.C. Field strengths of about 10 volts $/ \mathrm{km}$ (+ factor of 10) may be expected out to a thousand or so $\mathrm{km}$ from the burst. Grounded wire systems, e.g., power grids, phone lines, pipelines, etc., will serve as shorts to this earth potential so large currents may be produced. Being nearly D.C. it readily can enter $60 \mathrm{~Hz}$ power systems causing ohmic heating in the wires and most particularly transformers. Only the few very high voltage D.C. transmission systems and heavy duty equipment with large thermal safety factors are immune from this effect.
There are historical instances where natural magnetic perturbations from solar storms and aurora have caused outages in phone systems and power grids. Alaskan power systems have very high outage rates from auroral induced perturbations. D.C. currents of many to tens of amps are regularly noted to flow in their local power syslem. In the long; low resistance pipeline currents exceeding 200 amps have been measured.

The potential effects of this MHD EMP to the U.S. power grid will be damage to electrical wires and transformers, phone relays, etc. Such damage normaliy will require equipment replacement, a costly and lengthy repair process.

There is no evidence that EMP is a physical threat to humans. However, electrical or electronic systems, particularly those connected to long wires such as powerlines or antennas, can undergo either of two kinds of damage. First, there can be actual physical damage to an electrical component such as shorting of a capacitor or burnout of a transistor, which would require replacement or repair before the equipment can again be used. Second, at a lesser level, there can be a temporary opera- 
tional upset, frequently requiring some effort to restore operations. For example, instabilities induced in power grids can cause the entire system to shut itself down, upsetting computers that must be started again. Base radio stations are vulnerable not only from the loss of commercial power but from direct damage to electronic components connected to the antenna. In general, portable radio transmitter/receivers with relatively short antennas are not susceptible to EMP. The vulnerability of the telephone system to EMP could not be determined.

\section{Fallout}

While any nuclear explosion in the atmosphere produces some fallout, the fallout is far greater if the burst is on the surface, or at least low enough for the firebali to touch the ground. The fallout from air bursts alone poses long-term health hazards, but they are trivial compared to the other consequences of a nuclear attack. The significant hazards come from particles scooped up from the ground and irradiated by the nuclear explosion.

The radioactive particles that rise only a short distance (those in the "stem" of the familiar mushroom cloud) will fall back to earth within a matter of minutes, landing close to the center of the explosion. Such particles are unlikely to cause many deaths, because they will fall in areas where most people have already been killed. However, the radioactivily will complicate efforts at rescue or eventual reconstruction.

The radioactive particles that rise higher will be carried some distance by the wind before returning to earth, and hence the area and intensity of the fallout is strongly influenced by local weather conditions. Much of the material is simply blown downwind in a long plume. The map shown in Figure 6 illustrates the plume expected from a 1-Mt surface burst in Detroit if winds were blowing toward Canada. The illustrated plume assumed that the winds were blowing at a uniform speed of $15 \mathrm{mph}(24 \mathrm{~km})$ over the entire region. The plume would be longer and thinner if the winds were more intense and shorter and somewhat more broad if the winds were slower. If the winds were from a different direction, the plume would cover a different area. For example, a wind from the northwest would deposit enough fallout on Cleveland to inflict acute radiation sickness on those who did not evacuate or use effective fallout shelters (Figure 7). Thus wind direction can make an enormous difference. Rainfall can also have a significant influence on the ways in which radiation from smaller weapons is deposited, since rain will carry contaminated particles to the ground. The areas receiving such contaminated rainfall would become "hot spots," with greater radiation intensity than their surroundings. When the radiation intensity from fallout is great enough to pose an immediate threat to health, fallout will generally be visible as a thick layer of dust.

The amount of radiation produced by fallout materials will decrease with time as the radioactive materials "decay." Each material decays at a different rate. Materials that decay rapidly give off intense radiation for a short period of time while long-lived materials radiate less intensely but for longer periods. Immediately after the fallout is deposited in regions surrounding the blast site, radiation intensities will be very high as the short-lived materials decay. These intense radiations will decrease relative quickly. The intensity will have fallen by a factor of 10 after 7 hours, a factor of 100 after 49 hours and a factor of 1,000 after 2 weeks. The areas in the plume illustrated in Figures 6 and 7 would become "safe" (by peacetime standards) in 2 to 3 years for the outer ellipse, and in 10 years or so for the inner ellipse.

Some radioactive particles will be thrust into the stratosphere, and may not return to earth for some years. In this case only the particularly long-lived particles pose a threat, and they are dispersed around the world over a range of latitudes. Some fallout from U.S. and Soviet weapons tests in the $1950^{\prime} \mathrm{s}$ and early $1960^{\prime} \mathrm{s}$ can still be detected. There are also some particles in the immediate fallout (notably strontium 90 and Cesium 137) that remain radioactive for years.

The biological effects of fallout radiation are substantially the same as those from direct radiation, discussed above. People exposed to enough fallout radiation will die, and those exposed to lesser amounts may become ill.

There is some public interest in the question of the consequences if a nuclear weapon destroyed a nuclear powerplant. The core of a power reactor contains large quantities of radioactive material, which tends to decay more slowly (and hence less intensely) than the fallout particles from a nuclear weapon explosion. Consequently, fallout from a destroyed nuclear reactor (whose destruction would, incidently, require a highaccuracy surface burst) would not be much more intense (during the first day) or widespread than "ordinary" fallout, but would stay radioactive for a considerably longer time. Areas receiving such fallout would have to be evacuated or decontaminated; otherwise survivors would have to stay in shelters for months.

\section{Uncertainties}

The reader is cautioned that there are enormous uncertainties and 


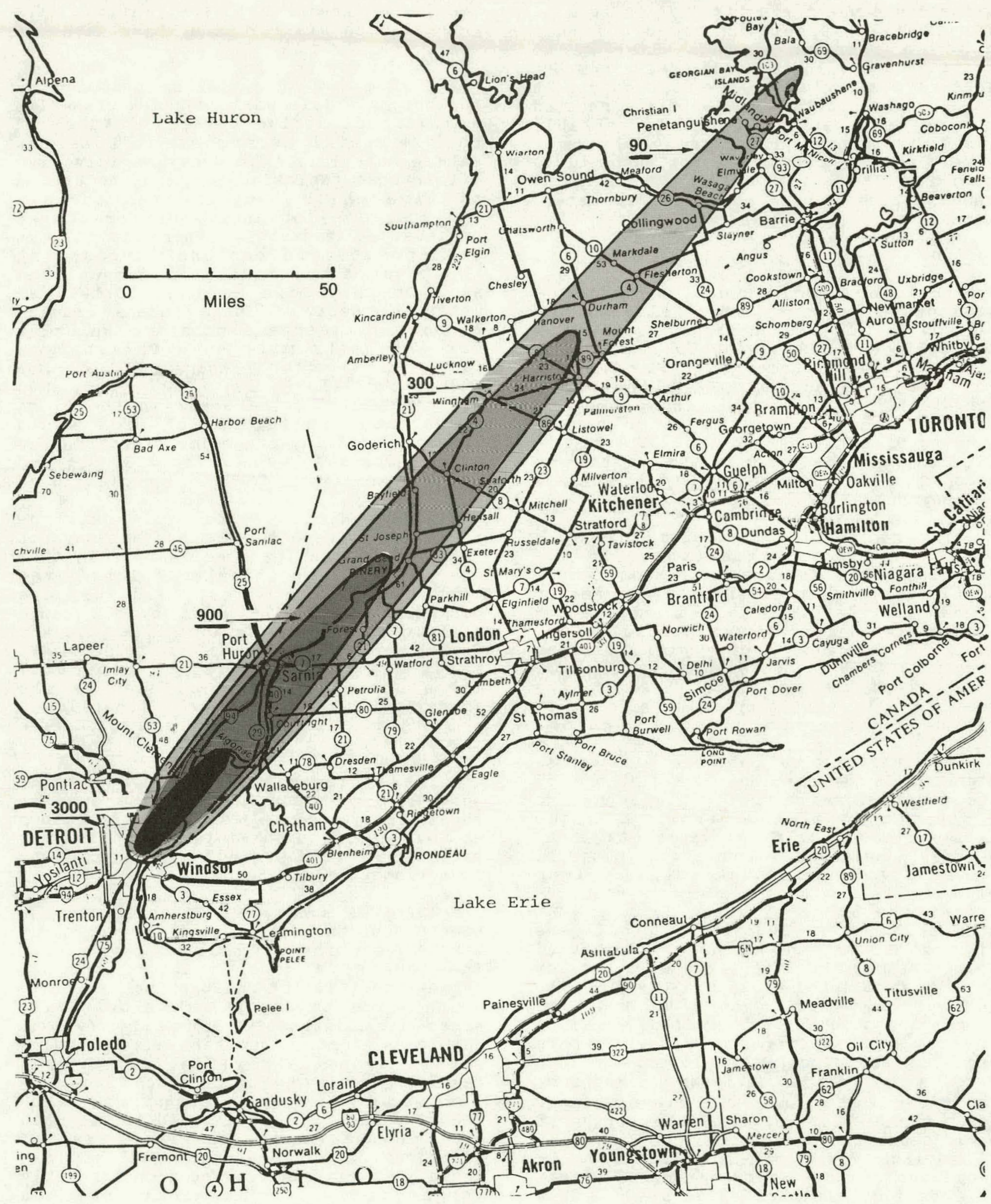

Figure 6 


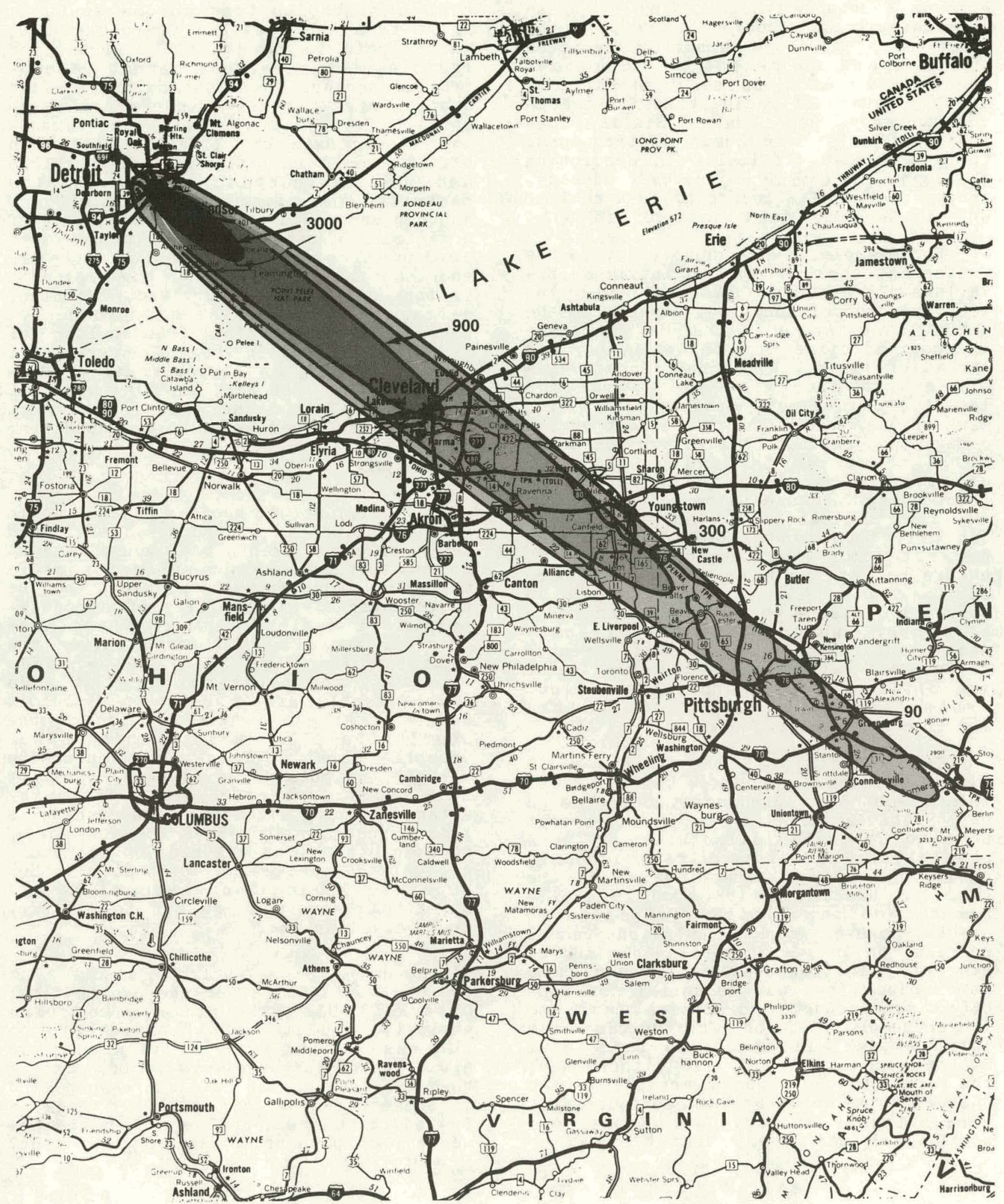

Figure 7 
imponderables involved in any effort to assess the effects of a nuclear war, and an effort to look at the entire range of effects compounds them. Many of these uncertainties are obvious ones: if the course of a snowstorm cannot be predicted 1 day ahead in peacetime, one must certainly be cautious about predictions of the pattern of radioactive fallout on some unknown future day. Similar complexities exist for human institutions: there is great difficulty in predicting the peacetime course of the U.S. economy, and predicting its course after a nuclear war is a good deal more difficult.

For example, a key uncertainty is the weather at the time of the attack at the various places where bombs explode. The local wind conditions, and expecially the amount of moisture in the air, may make an enormous difference in the number and spread of fires. Wind conditions over a wider arca determine the extent and location of fallout contamination. The time of year has a decisive effect on the damage that fallout does to agriculture-while an attack in January might be expectod to do nnly indirect damage (destroying farm machinery or the fuel to run it), fallout when plants dre young can kill them, and fallout just before harvest time would probably make it unsafe to get the harvest in. The time of year also has direct effects on population death--the attack in the dead of winter, which might not directly damage agriculture, may lead to greater deaths from fallout radiation (because of the difficulty of improvising fallout protection by moving frozen dirt) and from cold and exposure.

The question of how rapid and efficient economic recovery would be--or indeed whcther a genuine recovery would be possible at all--raises questions lhat seem to be beyond calculation. It is possible to calculate direul economic damage by making assumptions about the size and exact location of bomb explosions, and the hardness of economic assets; however, such calculations cannot address the issues of bottlonecks and of synergy. Bottlenecks would occur if a key product that was essential for many other manufacturing processes could no longer be produced, or (for the case of a large attack) if an entire industrial sector were wiped out. In either case, the economic loss would greatly exceed the peacetime value of the factories that were actually destroyed. There does not appear to be any reliable way of calculating the likelihood or extent of bottlenecks because economic input/output models do not address the possiblility or cost of substitutions across sectors. Apart from the creation of bottlenecks, there could be synergistic efforts; for example, the fire that cannot be controlled because the blast destroyed fire stations, as actually happened at Hiroshima. Here, too, there is no reliable way to estimate the likelihood of such effects would radiation deaths of birds and the destruction of insecticide factories have a synergistic effect? Another uncertainty is the possibility of organization bottienecks. In the most obvious instance, it would make an enormous difference whether the President of the United States survived. Housing, defined as a place where a productive worker lives as distinct from shelter for refugees, is another area of uncertainty. Minimal housing is essential if production is to be restored, and it takes time to rebuild it if the existing housing stock is destroyed or is beyond commuting range of the surviving (or repaired) workplaces.

Finally, actual nuclear attacks would not take place in a vacuum. There would be a series of events that would lead up to the attack, and these events could markedly change both the physical and the psychological vulnerability of a population to a nuclear attack. Even more critical would be the events after the attack. Assuming that the war ends promptly, the terms on which it ends could greatly affect both the economic condition and the state of mind of the population. The way in which other countries are affected could determine whether the outside world is a source of help or of further danger. The postattack military situation (and nothing in this discussion addresses the effects of nuclear attacks on military power) could not only determine lhe attitude of other countries, but also whether limited surviving resources are put to military or to civilian use.

Moreover, most analyses assume that the war would end after the hypothetical attack. This assumption simplifies analysis, but it might not prove to be the case. How much worse would the situation of the survivors be if, just as they were attempting to restore some kind of economy following a massive attack, a few additional weapons destroyed the new centers of population and of government? 
Appendix I

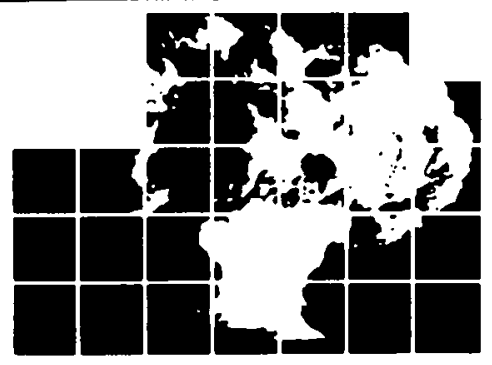

\section{Authorities}

\section{THE LEGAL BASIS \\ OF}

\section{EMERGENCY AUTHORITIES}
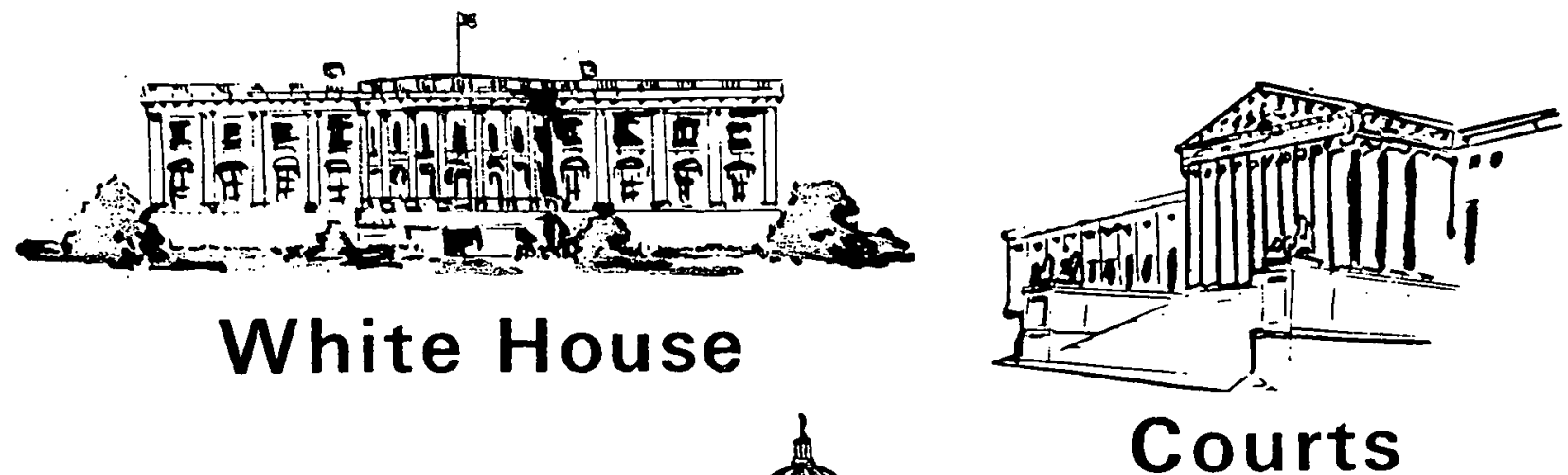

White House

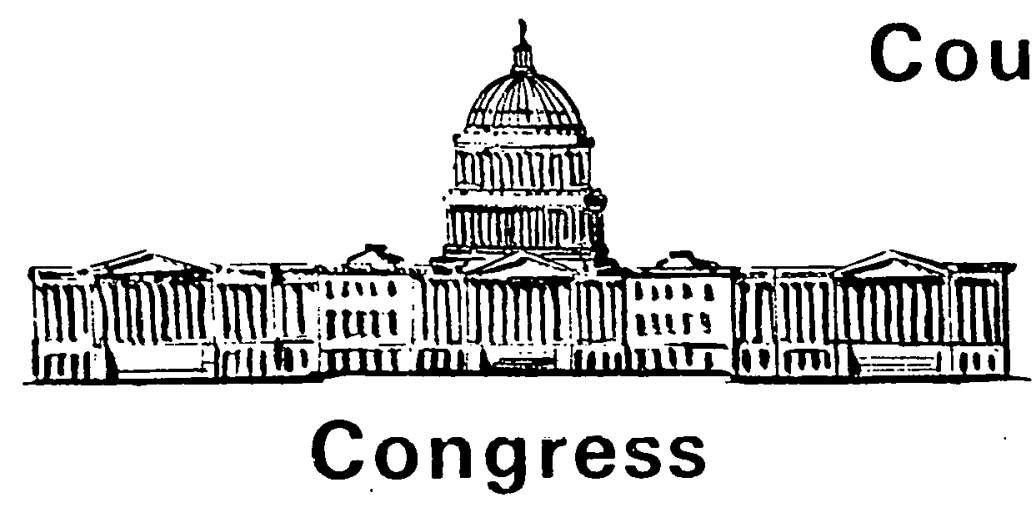




\section{Executive Order 11051 (dated 9/27/62)}

Prescribing Responsibilities of the Office of Emergency Planning In the Executive Office of the President

\section{Executive Order 11490, as Amended (dated 10/28/69)}

Assigning Emergency Preparedness Functions to Federal Departments and Agencies

\section{Executive Order 11921, as Amended (dated 6/11/76)}

Adjusting Emergency Preparedness Functions to Organizational and Functional Changes in Federal Departments and Agencies

\section{Executive Order 10480 (dated 8/14/53)}

Further Providing for the Administration of the Defense Mobilization Program (Part II includes delegations for priorities and allocations)

\section{Executive Order 10647 (dated 11/28/55)}

Providing for the Appointment of "Special Government Employees" Without Compensation Under the Defense Production Act of 1950, as Amended

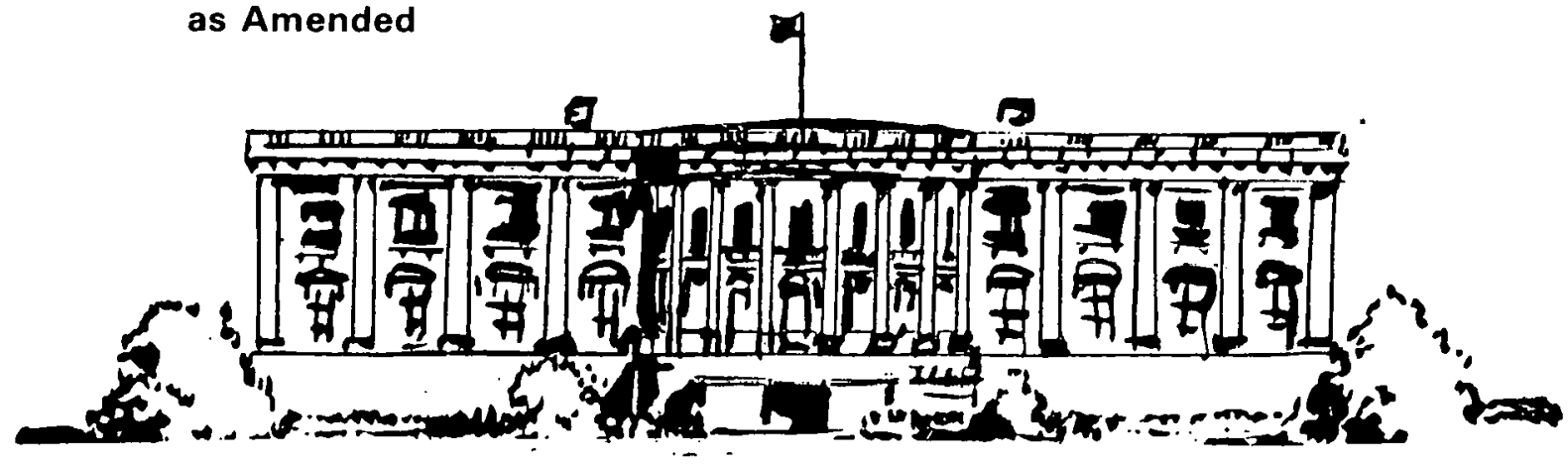




\section{Authorities}

\section{DEFENSE MOBILIZATION ORDER 3}

PART 103-DEFENSE PROOUCTION; PRIORITIES AND ALLOCATIONS AUTHOR. itr (DMO-3)

(1) Folleg guldaseo with regard to tho use of the Priorttes and sllocatloss suthor. it of utelo i of tbo Defease Production Act of 1080. as ameadod. and

(2) Delegation of such suthorth to cormis oncers and spencles.

1. Purpose. This order (1) estabUsties polley rutdance in accordince with sectlon 101 of Executive Order 10480 and sectlon 401 of Executive Order 11031. (2) delegates authortty in accordanco with scctlon 201 of Exesutive Order 10480, as amended, and (3) dele3atcs other authorfties under the Delense Production Act of 1950, as amended.

2. Carcellation. This order supersedes Defense Mobilization Order I-T. dated Ausust 14. 1953 (18 F $\Omega$ 5386) (redesibasated at 18 FR. 6737, October 23, 1953): Defense Moblllzation Order I-7. Amendment I, Revised dated Noveonber 12, 1954 (19 F.R. 7348); Defense Mobllization Order VII-3. Revised. dated January 10. 1956 (21 FR. 253): and Defense Mobillzation Order VI-3 Supplement 1, dated August 27, 1955 (20 PR. 6339).

3. Polictes. 2. Duthority af utle I of the Decense Production Act of 1050, as amended. to control the distribution ard use of malerin's and inclifties. shall not bo used except to require preference to the performance of contracts and orders and to allocate mntertals and facllttes to accomplish the following:

(1) Dircet milltary and atomic eaergs procrnms.

(2) Other prosrams and actirittes which are related to the milltary and atonile crergy programs and which are ecrtined by the Department of Defense or the Atomic Eucieg Commission and spectocally authorized by the Ollce of Emerzency Plannlog.

(3) Delivertes, production, and cos:struction la industry required to til.:ll dlrect millary and atomic energs ;ivTrams and the related programs and ictivitics authortzed under (2) above.

(4) Tho Eeiscral distribution in the etrulam anrket of materlals found to be sanres nnd erlileal pursunilt to bise provistons of section $101(b)$ of the Derenso Froriuction $\Lambda$ ct of 1050 , as amended. nnd alp)ioved by the director of the Oitlee of Emersency Planning under section 201 (b) of Exccutive Order 10480, as amended.

(5) Assistance in providlng metc:!als and facilities for the restoration of F:oductive capacity damaned or destroyed by a malor diszster as defined and determined under the provisions of Public Law 875. 81 st Congress ( 42 O.S.C. 1855):

(a) Whenever the laciltity to be restored has dellverg orders Identlifed by authortzed prograni identificat!on symbols under the dcfense matertals system.

(b) .Whencyer inllure to restore the lactlity rould result in fallure to mect a defonse dellvers schedulc.

(c) Whenever lallure to restore the facility wculd prevent the froviston of a scrvice necessary to meet a de?ense deIfverg schedule.

(d) When and to the extent that 25 sistance is necessary to restore mobillzation base capacity for the production of defense iterns loc!uding matertals and services covered by the Office of EmerBency Plannina expansion goals whether or not such goals remaln open.

b. The distrt!utton of stecl, copper. aluminum and nickel alloys : $\mathrm{cr}$ milltars and atomlc enerry and authorized related progiams and activities shall assure :

(1) That supplles of these contcrials are nuallable to tlose programs and ne- 
Uvities on tline and in proper quanttty.

(2) That demands of these programs and actlvilles shinl be distrlibutcd anong suppliers on a gerierally falr and equltable brisis.

(3) That allotments are not made in excess of actual current requirements of thesc progranis and actlvitics.

These criterla shall also apply to the maximum practlcable extent to the use of prlottles for malcrials other than stecl. copper. nluninum nind nickel alloys in support of direce milltary and atom!e encrey programs and other authortzed progianis and activitles.

e. The Ornce of Eincigency Planning shall revtew requirements and !ssue program determinations approving proErams and mat:ins allotments of stes!. copper, aluminum and Dickel alioys to the Departincat of Deferse and tice Alomle Eucrey Conuni:sion for direct milltary and neornle encizy prosrandis and treinted orterams and activilles l!:ne havo been nuthortzed and iss! inted to these arencles for purnoses of estallishIng them as programs cllglble for prtorttos and allocnlions support. in accordance with the Business and Defedise Scrtloes Aluinlstration reguiations lesued pursuant to Utle 1 of the Defense Production Act of 1950, as amended.

d. All sganctes now or hereafter destomated by the Director of the Ofllce of Emergency Planniag to furnish supply and. requiremerits data shall be rerpoastble :or the provtston of such dats and shall be entluled to be heard in conneetion with lise determinalion of prosrams by the Director. The evalustion of supply and requirements dala and the determination of programs shall be the function of the Director of Economle dFairs of the Once of Emergency Planalng with rieht of apreal to the Director of the Oflice of Emergency Planaing by any designaced ageney.

e. Exceptions to the foregoing bestc policg nas be made ta the interests of the astonal defense by or with the authorthy of the Director of the Ollice of Dmergenct P!analng.
4. Delegation of authority. a The sunctions of the Dircetor of the Omce of Emerzency Planning under the 1 of the Deferso Production Act of 1950, as arrended. nro hercby delegated to those onces and agencies unmed in section 201 of Exccullve Order 10480, ns anchded Tith respect to the arcas of responslbillthes designated. and subjest to the llontotions pirscribed in that section.

b. The functlons conierred upon the Director of the Once of Emergency Planning by section 310(b) and 311 (b) of Executlve Order 10480, as amended. to certify the cssentlauty of loans to the Secretary of the Treasury and the Export-Innort Bank of Washtrgton are herchy delcratcd to the Adminlstrator of Gencial Services to line extent that such lonns nre a nart of and in accordance with the terms of prostams ecrtined by the Dircctor of the Omce of Emergencs Plannina jursunnt to scction 312 of Excemtive Orter 10.180.

r. Tile finctions enuferred upon the Drector of the Omce of Emersency Plnnnlng by scellon 301 of Exceutlve Order 10.180, ns nimendel, telntlve to line chicournecinent of explorntton, development and minlntt of strnlerte nnd crttleal metals and minerals nre licroby dele-

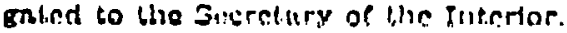

d. The funclions ctelegated by this order may be redeicailled with or without authorsty for eurther redelegatlon. and redelerations on the date hercol shall continuc in effect intll rescinded or modifled by approprite Rutbortts.

- Ollcers and agencles performing the functions delegated by this order or redelegated by, or by authortty of, the delegates hereunder shall perform such functions subject to the drection and control of the Dircctor of the Omce of Emergency Planning as provided by secHon 101 of Erecutive Order 10430 , as amended. Such offleers and agenctes shall furnish such reports on the use of the authority is the Director inay require.

[28 $\mathrm{F} \Omega$ 12104, Nov. 15, 1800 . Redeal grated at $10 \mathrm{FR} \mathrm{27218,} \mathrm{June} \mathrm{27.} \mathrm{1975]}$ 


\section{DEFENSE MOBILIZATION ORDER 4}

PART 104-GUIDANCE ON PRIORITY USE OF RESOURCES IN IMMEDIATE POST. ATTACK PERIOD (DMO-4)

1. Purpose. This Order. (1) states tho policy of the Federal Goverament on use of resources in the period Immedlately following a nuclear attack on the United States, (2) provides general guldance for Pederal, State, and locnl Bovernment omclals on activitles to be accorded prlority in the use of postaltack resources, and (3) lists those Items cssentsal to national survival in the ininedlate postattrck pariod.

2. Cancellation. Defense Mobllizntion Order 8500.1. Guldnnce on Prlorlty Use of Resources in Immedlate Postattack Perlod, dated April 24, 1964 (29 FR. 5796) is hercby sucerscded.

3. Gencral policy. In an iminedlate postattack perlod all declstons regarding the use of resources will be dlrected to the objectlve of natforial survival and recovery. In order to achleve thls objective, postattack resources will be assigned to activitles concerned with the maintenance and saving of lives, Inmedinto millitary defense and retailatory operatlons, and cconomic activities cssential to continued survival and recovery.

Tlus guldance is deslancd to nchicve a icgree of nnliomal crulty in tho use of resourecs nud to nsslen nnd conscrve resources effectlicly in the fimmedinte postnitick perlotl. Untll inore speelnc instruclions nre avnllable, these nre the gencral guldellues within whleh mnnnrerinl Judiement nuld conimion sense must be usidl to nchlteve untlounl ohjeceeliea umeler wielely aliter!n!? cmers:ency cindultlons.

4. licsinnsibllilics. As stalesl tin The Niational Pinn for Emercencs Prepnredness. the c!licetion of rennilirecs moblliz.2tion is a Fedcral responsibllity. However, in the perlod Imniediatcly following an attack, certnin geographlcal areas may bo temporarily isolated, and state and local governments will-assume responsibility for the use of resources remaining in such areas until eflective Federal authority can t.e restored. State and local rovernments will not assume responsibllity for resources under the Jurlsdiction of a Fedeinl abency where the Federal agency is able to functlon.

As soon as posslble after an attack and untll speclfic natlonal direction and culdance on tha use of resources is provided, Federal State, and local offclals will cetermine what resources are avallable, to what needs thes can be applied, how they are to be used. nind the extent to which resources are defleient or in excess of survival needs. They will base determinations as to the relative urgency for use of resources primartly upon the importance of specific needs of defense. survival, and recovery.

5. Priority activities in immediate postattack period. The following activitics aro to be accorded prlorlts over all other clalms for icsources. There is no signiflenneo in the order of the listing-all are importent. The order in whlich and the extent to whlch they are supported locally ming vary with local conditions and clrcumstances. If local conditions necessltate the establishment of nn order of priorlty nrrong these activltics, that order shall be bascd on determinations of relative urgency aniong the activitics listed. the avallablitty. of resources for achtcing the actions required, and the feaslblllty ar 1 timellness of the activitles in makdng the most rapld and efrective contribution to nntional survival.

a. The lmmedinte defense and relnila tory conbat ojerations of the $\Lambda$ rmed Forces of the Unlted Stntcs nnd Its Allles: This Includes support of millitnry personvel und tho production. and distributlon of millitary and alomic wenpons. materinis nnd equipment requited to carry out these Inumedlate defense and retallatory combnt operntlons.

b. Mnlntchance or recstubilshment of Govermment authority nnd control to restore and preserve order nud in nesuro diriertion of cmicrperncy operntions cssimllal for the salel.y nild prolectlon of Uho p:cople. Thits includes:

(1) Puliec protection nind moveinent drectlon:

(2) Fire defense, rescuc nund debrts clcninuce:

(3) Warnings:

(4) Eniergency Informatlon and instructlons:

(5) Radlolozical detection, monltoring and decontamination.

c Production and distribution of survival items and provision of servilces c5sentlal to continued survival and rapld rccovery. (For list of survival ltems, sce Appendix 1 to thas order.) Thinse include:

(1) Expedlent shelter;

(2) Food, Including necessary processLng and storage:

(3) Fecding, clothing, lodging, and other welfaro services:

(4) Emergency housing and community services;

(5) Emergency health services, in'cluding medical care, public health and sanitation:

(6) Water, fuel, and power suppls:

(7) Emergency repair and restoration of damaged vital facllities.

d. Essential communications and transportation services necded to carrs out the above aclivitles.

e. Proviston of supplics, cquipment, and repalr parts to producc and distributc coods needed for the above activities. 6. Assionment of resoutccs. Resources rcquired for csscntlal uscs, including manpower, will be assigncd to incet the emergency requircinents of the prfority activitles indicated nbove. The princlpal objectives are to use avalinble rosoureces to serve essenilal necds prompthy and cficcticly, and to:

a. Protcct and to prevent wnste or disslpation of resources prior to their assignment to prtority activitics;

b. Support production of cssentlaI goods. Other production will be permitted to continue on!s from inventorles on hand and when there is no emereency 
requirement for the resources vilal to this prociuction.

c. Support construction for emergeney repair and restoretion, construction of incliltics ni:ciled for survivil, or the conversion of fncllilles to survival usc, where this enn be neconiplislicd gulckly. Other construction niready under ning should bo stopsed, nnd no new conritruetion starled unless it con be used Immedintels for essentinl fumposes umon completion.

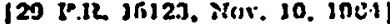

\section{Arjerindx 1}

T7ils clocunnenl enulalus a llit of ftems

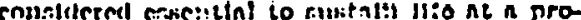
duretlen level to nesture mattoms currival in an eniergenes. Tho list Ideatlaes ltems to whicb msjor attention sbould be glren in all phrses of prenttack plannirg to Insure tho avallablitty of baste essentlals for a procluUve econong in tho erent of a nuclear nttick Supplj-requlrements otudies and nxussoreats for thcse ltems fill bo made to diseloso critloal deocleactes or ofber pmb. lems that can bo auticlpaled. Revbleos vill be uado at Decessary to liecp the iteme is up-ta-date as possible.

Tho ltems aro arransed by seven xoafor sroups:

(1) Menith Supplles and Equlpment.

(2) food.

(3) Body Prolectlon and Household Opera. tlon.

(4) Electrle Power nind Fucls.

(6) Snoltation acd Water Supply.

(6) Encrgency Houslug and Construction Mnterinis and Equipment, and

(7) Geהernl Use Items.

Survival ftems aro delned as most sterns vltbout phtch largo segments of tho popuiatlon rould dio or bare tbelr health so serlousig Impalred as to render them both bur. densours and non-productive." The ltems Dnve been classlaed into Oroup $A$ or Oroup B. with Group A sepresenting ead producto consumed or used directly by the podulation. and Oroup B consisting of those items esaentlal to the effective production and utllizatton of the Group A iters. Which are concumed or used dircetly. by the people.

Tyere are no Oroup $B$ items in the cate. gor:es of Health Supplles and Equlpment. Body Productlon and Household Operatlons. and Emergency Housing and Construction ara:er!sls and Egulpment. All of theso Iteans are conatdered to be concurned directly and ang nttempt to sepnrnte them in to $\Lambda$ and $B$ grouplags would be too atbletnry to be Eerelnge:sL

It is impoitnat to kesp in mind the sact ern: whlie the lterns listed nic the basle essent:als necessnry for malntaining a rinble ceonomy durlng the nrst slx months follntsing nn atlnck, Dot nll of them would create problems that would requlro government aciten piestincy to Insure ndcrunto cupplics. Tr:o sorcmentinned suppis-requircinents studles Fill bo untertnken to ldentlig the protisen crena. In dereloping supply onta, nll aralinble pmouctlon capnclty, extsting inventorles. and passtblo substitutions will be constdered. For example, in aoclgzing elouning llems. all avallnblo aupplles would bo considered from sport to dress slilrts. from oreralls to dress sults. Bowercr, Detr production would be $11 \mathrm{~m} / \mathrm{tc}$ to the simplest fores of the baste ltem wbleh can be produced. The nnal determinntion as to whtch of tho lienis are must erltleal anel whlleh ning requite prealtnct actjolls by the Governmenth ns well ns the type of actlons which snust bo enken, ean do miate only after a coinfrehesistic cuppij-tequltemento annlysto is esmpleted.
ILST OF ESSENTIAL SURYNAL ITEPSO

I. Realtb Supplles and Equlpment:

GROJP A

1. Phaimaceuticats:

Alcohol.

ADalgestcs, non-dircotle.

Antiblotlcs and antluacterlats.

Antldiabetle agents, oral.

Aotlatstnmioes.

Antimalarlats.

Atroplne.

Blood derriatlues.

Carbon dloxlde absorbent.

Cardiovescular depressanta.

Cardlovasculnz stimulaints.

Cortlecisterlods.

Dluretles.

Oonerni ancstheticg.

Eypnotics.

Iosulin.

Intravenous solutions for replacement thernpy.

Local anesthetiss.

Lubrleant, surglcal.

Mosphine and substitutes.

Oral electrolytes.

Oxyzen.

Burglcal antiseptics.

Sulfa drugs.

Bmthetle plasme rolume expnnders.

Vitamia preparatlons. pedlatrle.

Wabcr for lajootion.

2. Blood Collecling and Dlspensing Supplles:

Blood collecting and dispenslog contniner.

Blond donor scls.

Blood groupling aud tjplug sera.

Blood rectplent scts.

glood shlpplng contalners.

3. Biologicals:

Diphtherla toxold.

Diphtherin adtitoxin.

Diphtbcrla and tetanus coxoldo and partussls racelno.

Ora gancrene aditoxin.

Pollamyelltls vacelne, ornl.

Rnules vacelne.

Emallpox pncelno.

Tetanus antiloxln.

Telnnus toxold. absorbed.

Typhold rncelne.

Typhus rncelne, epldenle.

Yellow fever vacclne.

4. Surgleal Textlleg:

Adbesive plaster.

Bendage, gauze.

Bnndage, muslin.

Bandige. plaster of parls.

Cotton. USP.

Surgleal pars.

Stncklnctic, surglenl.

Wactillue. coltnu aliret.

b. Fmergeney surgiral Instruments cad

Supplles:

Alrwny. phargnecal.

Anesthesla npparatus.

Bnsin, rinsb. nolitlon.

Dlade, surglcal knlfe.

Brusb, ccrub, surgleal.

Catbeter, uretbrei.

Contaloers for sterllizaliout

Chlsel, bon=

Drain. Penrose

Dustlng poivde:.

Forceps, dresile:

Forceps, hemostattc.

Forceps, obsteirlcal.

Forceps, tlssue.

Qlorcs, surgeon's.

Handles, surglcal knlfe.

Holocr, suture ncedio.

Inbaler, arestbesla, Tonkaucr (cther mask).

Introvenous Injectlon sets.

Rnllo, crst cutting. 
Lamps, yor dlognostic lostruments. Lamps, for surglcal lights.

Inryngoseope.

Light, surgicnl, portable.

Ilter.

Maltet, bone surger.

Necdles, hypodermic, reusable.

Needles, suture, ejed.

Otoscope and opbthalmoscope set

Probe, general operatlng.

Razior and blades (for turglcal prepara-

tion).

Retractor, rb.

Retractos set, general operallag.

Rongour, bone.

Saw, aceputating.

Gaw, bose cuttlng, wire (OIgll).

Scfscos, bandage.

Gelssors, general surgleal

$6 l$ soollcoscopo.

Speculum. vazleal.

Bphyscomadometor.

Bpllnt, les. Thomas.

Spline wlie, ladder.

Steriblzes, preasure, portable.

Btethoscope.

Butures, absorbnbla.

Butures, absorbablo, with attached naedio.

Butures, nopabsorbable.

Sutures, nonabsorbable, with atizchod nectls.

Bjtiozcs. Luer, rousablo (bypodermilo syringcs)

The:rmometers, clloteal.

Tracheotomy tubo.

Tube, rasogastrle.

Tub!n3. rubber or plastic, and connectora.

Vascular prostreses.

Webs!oz, textlle, with bucisle.

6. Laboratory Equipment ard Supplles:

Bectorlological culture medis and apparom tus.

Balance, laboratory with welghts.

Blood and urlno aralysls lnstrumezts, cquitpment and supplies.

Cheasleni rencents, etalns and apparotue.

Olassivnto clmntring equinment.

Inbornlury glassivnre.

Mlleroscope and st!ctes.

Wnter plurinention npparnetus.

$$
\begin{aligned}
& \text { None. } \\
& \text { II Food: }
\end{aligned}
$$

1. Milk Group. Nutk in all forms. milk products. Important for calclum, stbedavin. protelo, and other gutrlents.

2. Mleat and Meat Altcrnate Group. Micat, poultry. Osh, eges; niso dry beass. pc2s, nuts. Important for protcla, fron, eod B-vitapila 3. Vegctable-Frult Group, Including. 1. Dark Oreed and sellor rczetables. Important for Vitamin A. 2. Citrus frult or other irult or vegetables. Important for Vitnmia C. 3. Other irults and rezetables, lacludtng potatoes.

1. Groln Products. Espcelnills eaxlched. restored, cercal and ecreal products, aod bread. flours, and mea!s. Importnnt for oncrgy, proteln, fron, and B-vitumins.

B. Fats and Otls. Ircluding butter, mar garlne. lard, and other cleortening olls. Important for palalnblitty and sood encrgy: como for Vitamin $A$ and cssentlal ratis nclds.

6. Sugars ond Syrups. Important for palotabluty and food encres.

7. Food Adfuncts. Certaln lood adjunct hould ve proplded to malio effectivo use of avallsble foods. These Locludo antloxicants and other lood preservatircs, jeast taklng powder, salt, cods. seasonings and atber condimerits. In adiltion, coffec, toa, aud cocoa aro Important for morale support.
Food contalacrs

Nitrozezous Iertillzcs.

secd and IIrestock reed.

Silt for llvestock.

Veterinary Mlcdical ltems:

Anthrax vacelno.

Black leg vnecine.

Hog cholera vacelno.

Nowcastlo paccloo.

III Body Protection and Houschold

Operatlons:

CROTP A

2. Cloenling:

Oloves and mitteras

Hesdreas.

Eosiers.

Outerwear.

Shocs and other footrcar.

Underwear.

Woterproof ouler garments.

2. Personal Hyglene $1 t c m s$ :

Dlapers, all types.

Disposabio tissuen.

First ald Items (Included on Healtb Sup

plles and Equ perent List).

Nipzles.

Nuriag bottios, all types.

Plns.

Snntary napiins.

Sonps, detergeuts, and distnfecinnls.

Tolles tlesuo.

3. Houschold Equiprocus:

Beditine.

Conned hent.

Cots.

Hnnt snolog crulposeze

Ifcatla nad cooz!ng tover.

Incardese at reud portable Hebtleg equipmeat (Includioz nasbight. larapa bat:erles).

Tutihen. coosinf. And esting utenslls.

Lremps (Ineandeiccot medium base) asd lemp hoiders.

sinteres.

ISonelnetrle llpasting equlponeat.

slceolng vegs.

None.

crova :

IV. Electric Poreer ard Puels:

1. Electrie Poter.

Electricl:-s.

osots A

G.00P :

Cosdictors (copper and/or alumilnum). Including bare cablo for hlgh roltago llaes and instilated firo or enblo for lower volingo dist-lbution glrculta.

Stoliches and clrcult breakers.

Insulators.

Dolo Ilne kardware.

Polce and crossarms.

Trnasformero (distribution, transmission, and mobllo).

Tools for Ure-clrcult operntions, Including rubber protectlvo cqulpment, and llag men's tools.

v thity repalr trucks. sully equlpped.

Prine morer generator sets up to 601 kllowatts and 2400 volts, lacluding po:tablo and mobtlo sots up to 130 klloratts and 210/220/440 volt3, 3-phess, 60-cycle completo oith suel tan's and switchgeas in sele-contalaed unlle.

2. Pctrolcum Products.

Ginsoltine.

croop. 1

Kercurne.

Dis:l:Into Puel oll.

Reridun: fucl oll.

Liquened putrn!eum oll.

Liilirtenting oll.

Orerno. 
Storneo innks.

Puimpa for Inadling and unlondlog.

Presvito contalicrs and filtings for IIqueniel pelvoleum $5.2 x$

3. Cas.

crotr A

Sinturnt gas.

Branufnetured gan.

CRDOP a

Varloun alzes ce plpo (mostig ated).

Vorlouts etzes of valres, nttlrigs. and pressurn regulntors.

Spect:allred repmir truets nnil equ!pment.

4. Solid Fuet.

\section{enoup A}

Conl nud cote.

\section{erote}

Convesor belliog.

Insuinted tenll cables.

Trolley reeder pilre.

nool bolts.

V. Santlation and Tater Supply:

1. Water.

enof A

2. Voter Supply Malelals:

a. Coggulation:

Ferrlo chlo:lde.

Iterrous aulfate

Perric aulfats.

onlortiated coyperas.

Filter slum.

Estrated ine.

Pulverlzed limestone.

Soda asb.

b. Districetlon Chemicals:

Bigh-test bgpochlorites (To percent) in drums. cans, ampules.

Iodino tiblets.

Liquld chorine, including contalners.

Chlorlae comwunds (not gas).

c. Artscellancous irćtertals:

Dlatomaceous eartb.

Activated carbon.

3. Criemical Dlological and Radioloytal (CBR) Detection; Prolectior, and Decontamination ltems:

Callbrators.

Chemical agcat detectlon 2Jts. vir, lood.

- and water.

Doslmeters and chargers.

Potective masks, clotblog, beimets

Survey meters (Aiphn, Beta, O.rmmn).

Warning stgns-blologtcal, chemleal, and radlologlcal concamiasuon.

4. Insect and Rodent Controt Items:

a Insrellatdes:

Dor. nater disperstblo powder $(75$ percenic).

Ilindingo poxder, dustipg (1 percont).

Minlathlon, liquid, einulilobblo concentrato (67 parcent).

Deot (dlethyltoluamida) $T$ porcont lii cointured nicohol.

Brolinnin.

b. Rodeniletics:

Ankleoaguinnt typo, ready-mixed balt.

"M080" (eodlum monolueroncetoto) (I0s controltril uno only).

b. General Sentlation:

Iye.

\section{onors :}

1. Geteral Supptles and Equipment: Oremieal ieeders.

Acobue nod portnblo pressuro niters.

Chlorinntors (sns and aspocblortics).

Pumps nad nppurtenances, Irnad-inestrie-Onsullno-Dlesel.

Well-drtlling cptulpincut, Including fidl

enrtne. ditive plpo and cirlvo poluta.
2. Sturuge atud irransport Equlpment:

Lyster bnes.

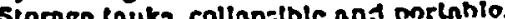

stornipo tanks, rleld, tranapietnisir.

Glomro tanks. wosd olnve. knock-diotin.

8. Leboralory Equtpment and Suppltes:

Membrane alter lits with alters and media.

Calorino and pF determbation equpment.

1. Santlation Equtpinent:

Jand spraser, conisinuous types

Finnd sprayer, compression typo.

Ennd duster. plunger t5pe.

Eprayiag coutpment for uso with bellcopter. Axed-wing light alrctaft. hlgb-speed frod-oing attark alreraft, and cargon tspo alrexalt.

VL. Emergency Housing and Construction Malertals and Equipment.

oxoor A

Apphalt and tnr rooeng and slding pjoduota.

Bulldero bardwaro-nlnges, looks, bandiss. etc.

Bullaing board. Inaluding insulating

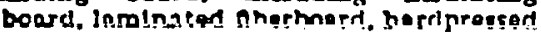
aberboard. Brpsum board, and risbestos cement (lat sheets and pollbctid).

Bullding papers.

Plast!c patcblog, couplings, clamps, te. sor-eonerbeney repalrs.

Plurablag axcures and attings.

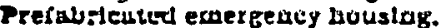

nough bardwaro-Dalls, bolts, screws, ota.

Sorer p!pe and Aturgs.

Teats and tarpaullos; canvas, plastlcs, and otber slollar materlals.

- Lumber and altied products: Lumber. prinetpaliy 1-10ch sad 2-1neb, minor quanultes of small and large timbera; slding and doorlag: plgwood: mlllwork, doors. and pladows.

alnsoen prodizets-brlex, cernoat, limo, concrete block, hollow tlie, otc.

Translicent wladow coverlngs.

Unter pipo and hone, plus attogs-all types lncluding aro haso.

trono.

arour :

VIL Gencral Use Items.

Nons.

choop a

onotos D

Bntterles, Ret cod dry coll.

Dulidozers.

Firo Aghting oquipment.

Libist eyulpuscit uad band tools (Including olectrio powered) for entpenery. masoviry, plumbing. nṇt nrengetinn.

Pipo Instnilintion mntertals and equapment.

Rolrigerators, mecbantcul.

Rieklor lools-enbles, ropes, tnckles, bolsts. otc.

Tank ralliond en:s.

Tnnk Trueks and trallers.

27ren.

Trenchlng nquipment.

Truck trnclors nill trallers, Inclitipe low bed.

Trucks up to nvo tons (25 parcent equipped with porter takcor).

Welding equlpment and supplles (clectic ancl ncetjlicte).

129 FR 16124. Nov. 10. 1991. Redes!guated at $10 \mathrm{FIR} \mathrm{27210,} \mathrm{Juno} \mathrm{27,} \mathrm{1075)}$ 
FEDERAL EMEAGENCY

MANAGEMENT AGENCY

\section{CFR Part 322}

Delegation of Certain Detense . Production Act; Priorities and Allocátion Authorities

AGENCY: fioderal Emergitili:

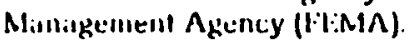

Acrinn: Final rule.

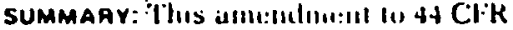

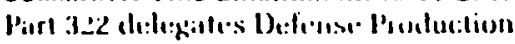
Art lible 1. promilie:s astud allow:oliuns authurity lo lle Sectetetiory of

Trunsportalion in the ares of civil Iransportution siervices.

EFFECTIVE DATE: August 12, 1916. FOR FURTIEA INFOAMATION CONTACT: Cliair K. Blong or Charles Mclutush. Mesuurces Milllalfeme:nl Division

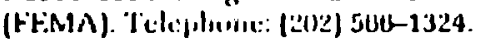
SUPPLEMENTAAY INFORMATION: "This

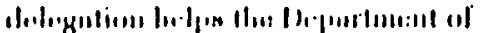

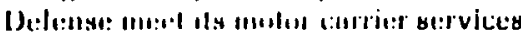
requirtmenly in delt:ast: conlingencies by provicling the: Siccereliary of Iriansinerlations ovith mollobrily lo expenditionsly carry out his le:udership

\section{DEFENSE MOBILIZATION ORDER 11}

PART 111-EENERAL POLICIES FOR STRATEGIC AND CRITICAL RAATIRIALS STOCKPILIAIE (0:10-11)

1. Purpose. Tils order scis forth reviscd policics for the aimitistrilion o: strntecle nnd critlcal materlals steckplling.

2. Cancellatton. This order supersedes Defense Mobilization Order 860C.1A (33 FR 19079, Dec. 21. 1958).

3. Policiss. By virtuc of the authortly resied la ine by Exccutlve Order 11051. the following polleies nre promulgated to goveru the aclminlatration of strategle and critical matcrials stockplling:

a. Gencral. The strateglc stcekplle shall be so adminilstered as to assure the arnllabillty of stratcric and crltical materials in tintes of notloind concrgeneg.

b. Pctiod covered by stockpiling. All strategic stockplle objectlies for conventional war shall be limited to meetlng estimated shortages of materfals for the Arst year of a war.

c. Stockptle objectivcs. Strategic stockplle objectives shall be adequate for supplies of these materials in time of natlonal emergency.

d. Encrgency requlrements. The requirements estimates for use in times of national erocrgency, where appropriate. reflect specific requi-ements to the extent available. It shall te assumcd that the total requirements will approximate the capactly of Industry to consunse, taking into account neccssnry wartime $1 \mathrm{~m}$ tation. conservation and substitution mensures. Departments and agcncles

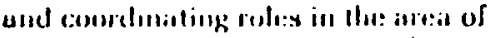
civil tratespentaliem servicess. This anendment lo $+4+\mathrm{CY}$ K l'arl 322 is not

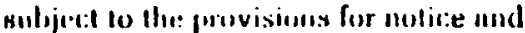
pulilic common:.11 in s ll.s.C. 55j becanuse it involvis: the: military fumbliun of the tluiled Sialles.

\section{$\$ 322.3$ (Amended)}

Accurdughly. $4+$ C:IR. Chapler 1. 8322.3 is anm:nele ol by renumbering

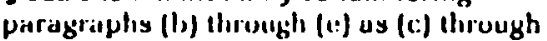
(I) and adding a new paralgraph (b) as fulluwg:

(b) The functions conferred upun the Direclur of the liectoral Finergincy Managentent $A_{\text {guomity }}$ under T'ille 1 of the Defenge Pruiluition Act of 1 (ISO) as umended. with respnec:t lo priurities and allocistiuns for civil Iranspartalion services are herelsy dele:gilled to the Secrelary of Transportation. sul,ject to the limitutions prescribed in this regulation.

Juhn W. Macy. Jr.

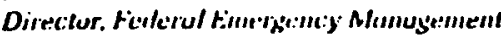
Agency.

August H. (U)ik).

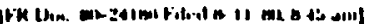

OlLSIMC CODE 6rio-01-4 hoviat responsibilltes with recard to renuirements dala on stockplle materials shall review such data and provide, upon his request. the Director of the Orace of Emercency Preparedness with information as to all slemincaut chnnges.

e. Emcracncy supplles. Estlmates of supisly for the mobilization period shiall be based on readlly avallinble capacity and known lesourees ln the Unlted States nnd such other cnuritrics as dliected by the Nallonal Security Councll. Dejurtments and agencles having the responsibllitles wilh resard to supply data on stockplic materinls shall revicy such dita and provicle the Dirsetor of the ofnce of Fincrgency Preparcdness, unon his reqiacst. Will duforination as to all signine:ant clinnecs.

f. P'nuiston for spicirel-promerly malcrinls. Arrangemenls slınll be made for thre Iremulal nvallnilllly of objectllue scl-

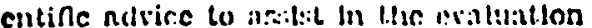

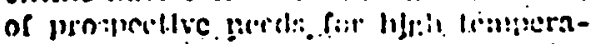

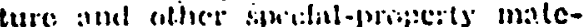
ri:tl: Sjoch malcrinls shall be stoclipllod

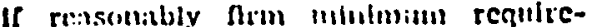
ments Indicate the extstence of a suppiy defleit in the event of an cmerecncy.

g. Supply-requtrements reolcius. The supply-reinircuicuts balance for ails milterlal that is now or may become Inuprtant to dufense shall be kept under contimulng surveillance. Suppls-requircmer.ts data submitted pursuant to paracraplis d. and $c$ above sliall be cxamined upen recelpt. A full-scale revlew nan be undertaken nt any tlme that a change is belleved to be taken place that would 
have a significant bcaring on the varthros rcadiness position. Prlority of revter shall be glven to materlals under procurc. ment.

h. Procurement policy. Unfilled obJectives shall be attalned expeditlously by cash procurement or otbertitse as the Director shall deem aopropriate. Longterm contracts shall contain termination clauses whenever possible. All teaslbli: measures for meeting materlals deficit: in an emergency shall be considered. stockplling shall be undertaken only when it is clear that it is the best solu. tion.

1. Melntenance of the mobtlization bese. A portlon of the mobllizitlon base comprises existing or prolected productive cnpnctly the output of which will be relled on to nil defense requirements. All inventorles of Government-onned nisterials held for lonc-terin storage are a part of the moblilzation base and should be welghed in determining the need for a relevnat portion of the productlve scgarent of the moblliyation base. Tho maintenance of any portlon of the productive segment of the mobliznt'nn base throush stockplle procurement slinll be undertaleen only within unglled stockplle objectlves.

1. Upgrading to ready usabllity. In order to satisiy the Initial surge of abnormal demands following intenslve mobillzation In a perlod of natlonal cmer. gency. stochplle objectives of ungindicd corms of such mnterlals shall be cstnlbllshed for immedinte use in sticli circiunstnnces. For this vurpose a mintmiun rendiness inventory shall be provicied nenr centers of coustumullou. Mnteria!s In Coverument Inventoiles mny be uylanelu do for such storliplline purpuses only

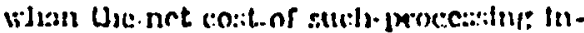
cluilu: transportatlon and hanellun t: less than the coil of mew minicritt. Mt:blerials should be ubaraded to forins whleh will permit the greatest use-flexlbillty. Surplus materials may be used to pay for the upgradine of the sanie or other matcrinls requlred to mect objcctlves providing that the use of cxecss matertals for thls purposo is in conformance with disposal criterta.

k. Derefictatlon of subspect/cation matertals. Subspectacntlon-mrnde mater1als in Govermment Inventorles mas be bencliclated withts the limits of the objectlves when this can be accompllshed at less cost than buylng new materlal.

1. Cancellation of commilments. Commitonents for dellverjes to natjonal stockplle and Defense Production Act lnven. torles beyond the objectives shall be canceled or reduced when settlements can be arranged which would be mutually satisfactory to the suppller and the Govermment and wblch would not be dlsrupUre to the econozisy or to projects essenHal to the astional securlty. Such settle- ments may take lnto account anticlpated proats and cover adjustments for abovenarket promiums. The settlement of commitments may be made through the payment of cash or through the use of surplus materlals. Responslbllity with respect to the settlement of commitments in the light of overnll Intercst of the Oovernment rests with the Administrator of General Services who shall keep other agencles advised and consult with them to the cxtent appropriate.

m. Retcrtion of other inventortes. within the llonits of unflued stockplle objectives, stockplle-grade mnterlals in the Defense Production Act nnd the supDlemental stockplle inventorles shall be retalned for natlonal stocknile purposes.

n. Dlsposals. The Dlrector of the Ollce of Emargency Preparcdness will authorize the disposal of excess matertals only after duc regard to: (a) Avoldance of serfous disruption of the usual markets of producers, processors nnd consumnrs. and (b) the protocllon of the Uulted slates acalnst avoldable loss.

In genernl, excess minlerinls constlluto unnerded nessts nnel alinll be disposed of as cxicellelously no posslble.

In making such ditiposnls preference shall lic clvon to malerinls that delertoratc. Uliat nre likely to become obsoicte. that so not mect nuality standarrls, or that do not have storkplic olsfectlecs.

The Admlnistrator of General Scrvlces shall be responsible for disposal of cxcess matertnls. He shall advise the Scerctnry of State and the Assslstant to the Presldent for Econonile $A$ Ealrs in adranco on all disposal plans.

o. Government use. Under such pollcles and procedures as the $\Delta$ dminlstrntor of General Services may proseribe, Government ngencles whlch directly or Indtectly use stratestc and critleal matertals shall fuln!l thetr regulroments through the use of materlais in Government inventories that are excess to the needs thereof. Dlrcet use means use in a Government-owned and operated facillty and use in a Govemmez:-orned faclitty which is operated by a contractor for the Government. Indlrect Government use means use by primo contrictors and all tlers of subcontractors in the production of ltems belng procured by the Govornment.

4. Delegation of authority-Preparation of reports. Tlie Adminstrator of General Servlces shall prepare on bchall of the Dlrector of the OQlee of Emergency Preparedness and folmard to him for transmittal to the Congress the reports icqulred by section 304 of the Defense "-oduction $\Lambda$ ct of 1950, as nmonded, nr.t section 4 of the strategle and Critical iratcrlals Stock Plling $\Lambda$ ct. 138 FR 0507. Apr. 17. 1073: 30 FR 10111. Apr. 27, 1073. Redesigunted ne 40 FR 27218. Juno 27, 1076) 
THR. IF.FFNSE PRODUCTION ACT OF 1950, ${ }^{2}$ AS $\triangle$ MENDED *

AN ACT To exinullall a system of prlorltieg nnd allochuons ror materials and

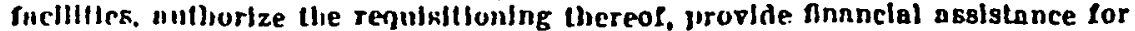
expnusion of froductive cajmclts and suppls, pmolde for frlce apd wage staiflization, provide for the sctilement of labor dispules, strengtben controls over credit, and hs liesp weasures facllitate the production of goods and services necessary for the nntlonal sećurity, and for oller purposes.

Be it enocted by the Senate and House of Reprcsentatives of the United States of America in Congress assembled, That this Act, divided into tilles, mny be cited as "the Defense Production Act of 1950."

\section{TABLF OF CONTENTS}

Titie 1. I'ruarlter and allerations.

Title II. Autborty to revulsitlon and condemn.

Tytte III. Expansion of productive cajaclts and supply.

Title JV. Price nnd wuge stabllization:

Title V. Settlement af la bor disputes.:

Title VI. Control of consuroer nnd renl esigte credit.

Title VII. General prorislons.

DECLARATION OP POLICY

SEc. 2. (50 U.S.C. App. 2062) In view of the present international siluntion and in order to provide for the nationnl defense and national security. our molilization effort continues to require some diversion of certain materials and facilities from civilian use to military and related purposes. If. also reguires the development of preparedness progranis and the expansion of productivo capncity and supply beyond the levels nceded to meet the civilinn demand, in order to reduce tho time required for full mobilization in the event of an attack on the United Stater wor to respond to retions occurring oitsdde of the Dnited Btates which cowd result in to termalnation or reductlon of twe turulubluty of strategtc and caltical materisels, including energy. and whlab pould edveraly aflect the national defense preparedoen of the Dalted Btates. In order to insuro tho nattonal defenso . preparedness wisich is esential to astional secultity, it in

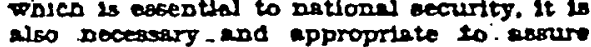
domestle onergy supplies for astlonal dolense Deads.:

In order to insure productive capacity in the event. of such an attack on the. United States, it is the policy of the Congress to encourage the geographicnl dispersal of the industrinl facilities of the United States in the interest of the uationnl defense, and to discourage the concentration of such productive facilities within limited geographical arens which are vulnerable to aftack by an enemy of the United States. In the construction of any Government-orned iridustrinl facilities, in the. rendition of any Government finnncinl assistance for the construction,

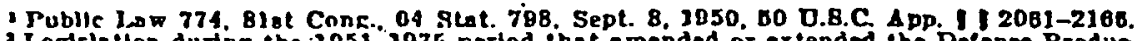
- Leptsintlon durior the $2051-2075$ period ibat ameaded or extended the Defenne Produetion Act of 1950 in jinted below on 113 . Solloned by a listing of bections of tbe Dalted Binten Code a tecled by this lerlalation.

intborty to coddemn odded Jujs 81. 1951 : title termlated at the close of June 80, 1058.

- Authority lerminated at the clope of A pril 30.2053 .

- Control of connumer credit terminated Jube 30. 1952. Control of real entate credit termiusted at the close of Jude 30,1853 .

(77)

extended to Aug. 27, 1980, by SJR 175

extended to September 30, 1981 by the Defense Production Act Anendments of 1980. 
expnusion, or improvement of nuy industrial facilities. and in the procurement. of groods and services, under this or any other $\Lambda$ ct, ench department nnd nency of the Executive Jirneh shall npply, under the coordinntion of the Omice of Defense Mobilization. whicn practicalle nnd consistent witl exisling law and the desirnbility for mnintrining a sound economy, the principle of the greorruplical dispersal of such facilities in the interest of national defense. Nothing conlained in this parngrnph sliall preclude the use of existing industrial facilities.

\section{TITLE I-]'RIORITIES ANI AI,LOCATIONS}

Szc. 101. (50 U.S.C. App. 2071) (a) The President is hercby authorized (1) to require that performunce under contrncts or orders (other thinn contracts of employment) which he deems necessary or appropriale to promofe the nationnl defense shall take priority over performance under any other cont.ract. or order, and, for the purpose of nssuring such priority. to repuire acceptance and performance of such contracts or orders in preference to otloer conitrnats or orders by nny person he finds to be copable of their performance, and (2) to nllornta materinls and fncilities in such manner, upon such conditions, nnd to sucli extent as he shall deem necessiry or approprinte $w$ prumude the national defense.

(b) The powers granted in this section shall not be uscd to control the general distribution of any materinl in the civilian minrket unlere the President finds (1) that such matcrial is a ecarce and criticnl inaterial essential to the national defense, and (2) that the requirements of the national defense for such material cannot otherwise be met without creating a significant dislocation of the nornal distribution of such material in the civilinn market to such a degrec as to creatc apprecinble hardship.

(c) (1) Notwithstanding any other provision of this Act, the President may, by rule or order, require the allocation of, or the priority performance under contracts or orders (other than contracts of employment) relating to, supplies of materials and equipment in order to inaximize domestic encrgy supplies if he makes the findings required by prragraph (3) of this subsection.

(2) The President shall report to the Congress within sixty days after the date of ennctment of this subsection on the manner in which the authority contained in parngraph (1) will be administered. This report shall include the manner in which allocations will loe mnde, the procedure for requests and appenls, the criterin for determining priorities as between competing requests, and the office or agency which will adininister such authorities.

(3) The authority granted in this subseclion may mot. lin used to require priorit. p performance, of contifacts or orders, or to control the distribution of any supplies of materia)s and exuipment in the marketplace, unless the P'resident finds that-

(A) such supplies ure scnrce, critical, nud essentinl 10 maintain or further (i) exploration, production, refining, transportntion, or (ii) the conservintion of cuergy supplies, or (iii) for the construction nnd mnintenance of energy freilities; and 
(B) mnintemunce or furthernnce of explorntion, production, refining, trmusportation, or conservation of energy supplies or the construction and muintenance of energy facilities cannot rensonably be necomplished without exercising the authority specified in parngraph (1) of this subscction.

(4) Juring nny perial when tho authority conferred by this subsection is heing exercised, the President shall inke such action as unay be oppropriute to nssure that such authority is being exercised in a manner which nssures the coordinated administration of such authority with any priorities or allocntions established under subsection (a) of this section and in effect during the same period."

SEc. 102 . (50 U.S.C. A pp. 2072) In order to prevent. hoarding, no person shall accumulate (1) in excess of the reasonable demnnds of lusiness; [e/sonal, or hone cousumption, or (2) for the purpose of resnle at prices in excess of prevailing mnrket prices, materinls which have been designated by the J'resilent us scarce materials or matcrials tho supply of which would be threatened by such accumulation. The President shall order publistied in the Federnl Register, and in sucb other manner as he may decn appropriale, every designntion of materials the sccumulation of which is unlawful and any withdrawal of such designntion. In making such designations the President may prescribe such conditions with respect to the uccumulation of materials in excess of the rensonable demnnds of business, pereonal, or home consumption as he deems necessary to carry out the objectives of this $\mathrm{Act}$. This section shall not le const.rued to limit the authority contained in sections 101 and 704 of this Act.

SEc. 103. (50 IT.S.C. App. 2073) Any person who willfully performs any act prohibited, or willfully fails to perform any act reyuired, hy the provisions of this title or any mile, regulation, or order therennder, shall, upon conviction, be fined uot. nore than $\$ 10,000$ or imprisoned for not more thin one year, or both.

SEc. 104. [The nuthority contained in this section was added by the Defense Production Act Amendments of 1951, .65 Stat. 132. July 31,1051 . The nuthority was terminnted nt the close of Tune 30,1953 , by section 11 of the Defense. Pioduction Act Amendments of 1953, (i) Stal 131, Jume 30, 1953.]

Bec. 205. Notblap in thle Act shen bo con-

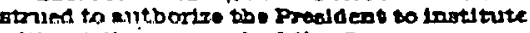
wthout the appropal af the Conkress, a proEram far the ratjonting of gasoline among classes of end-usera.

-Brc. 108 . Por purposes of thls Act. energy. ahall be deslensted as atraterle and critical material arter the Ante of the enoctoment of

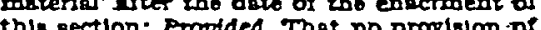

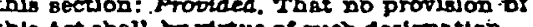
th Act saill, bo viruo of such desirantiab(I) xrant any Dew olrect or Indirect $\mathrm{au}-$ tharts to the President for the mandatory ellosation or priclop of any fuel or leedotocx (inclueine. but-not Ilralted to. crude oll. resldual fuel oll any retiod petrol etwo produet, natraral pas, or coal) or electrictity or any other form of energy, or

-12) grant anj dew diroct or lodirect authorttr to the Proddent : to engage - in tho production of energr in enp.mander whatsocour isuch as all and pas orolorstion and Dovelosmeat. or eny ederzy fachito conatruotion). exceot as expreselo provided in sectlons 805 and 808 for synthetle quet production.".

\section{TITLE II-AITTHORITY TO REQUISIT:ON AND CONDEMN}

[The nuthority to condemn was ndded by section 102 of the Dofense Product.jon Act. A mendments of 1951, 65 Stat. 132-133, J Inly 31, 1951. The title. was terminated ns the close of June 30, 1953, by section 11 of the Defense. Production Act. Amendments of 1953, of Stat. 131, June 30, 1953.]

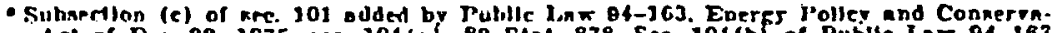
llon Art of Dre. 22. 1875. kec. J04(0). 89 Stat. 878. Sec. 104(D) of Public Low 84-163 provinien further:

(1) The suthorlty to farue any rulea or nrdera under arction 201 (c) of the Detenoe

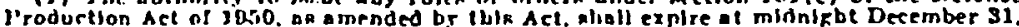

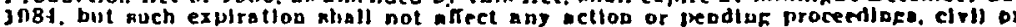
criminal. Dol nnally determined on such date, por anj actlon or procecding based upon any act comintited prlor to nurb onte

(2) The explratoly of the Delenne Produellon Act of 3850 or any auedimeat of auch Art nfier the date of enactment of thin Aet mball not affect the uuthority of the Presinent under nection 101 (c) of such Act. an amended bj sulisectod (a) of

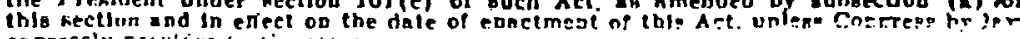


Sec. 301. (50 U.S.C. App. 2001) (a)(6)In order to expedite production and deliveries or survices under Govermment contrncts, the l'resident mav authorize. subicct to such regulations as he may prescribe, the Department of Defense, the Department of Energy, the Department of Commerce, and such . other agencies of the United States engnged in procurement tor the national defense as he may designate (hereinafter referred to as "guarantecing agencies"), without regard to provisions of law relating to the inaking, performance, anendment, or modification of contracts, to guarantec in whole or in part any public or private financing institution (including any Federal Reserve bank), by commitment to purclinse, agrecment to share losses, or otherwise, ngainst loss of principal or interest on any loan, discount, or advance, or on any cominitment in connection therewith, which unny be mnde by such financing institution for the purpose of financing any contractor, subcontractor, or other person in connection with the performance of any contract or other operation deemed by the guarnntecing agency to be necessary to expedite produetion and deliveries or servjers under Govcinment contracls foi the proeurcment of materipls or the performance of services for the uational defensc, or for the purpose of financing any cuntractor, sulxontractor, or other person in comnection with ar in contemplation of the termination, in the interest. of the United States, of any contract made for the nntionnl defense; but no smallbusiness concern (ns defined in section $714(a)(1)$ of this $A c t$ ) slinll be held ineligible for the issuance of such a guaranty by reason of allernative sources of supply.

\footnotetext{
-C) Except as provided in wecalan $\mathbf{3 0 6}$ and rection 308. no authortt contelned in roctlows sor, 202 , of 308 mong be used in ang mannar-

-(A) in the develapmant, production or distedbution of synthetic Inel;

(B) Lar ang eynabetie suel project.

(C) to sastet any perton for tho purpoes

ol providing poode or worvicee to to synthetio

tual profoct: or

* (D) to provide ang aseletanco to :eng

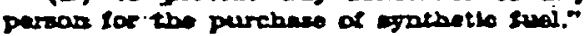

(b) Any Fedieral agent:y or any Federal Reserve bnnk, when designateil by the President, is herchy nuthorized to act, on hehalf of any guarantecing ngellcy, as fiscnl ngent of the United States in the mnking of such contracts of gun rustee und in otherwisc enrrying out the purposes of this section. All such funds as may le necessary to enahle any such fiscal ngent. to carry out. any guninnitee made. by it on behnlf of any guaranteeing agency shall be supplited snd dishursed by or under anthority from such gunanteeing agency. No such fiscnl agent shnll have any responsibility or accouni nbility except. ns ngent in taking any nction pursunnt to or under authority of the pmoisions of this section. Each such fiscal ngent shall be reinbursed by ench funranteeing agency for all expenses and losses incurred by such fiscul ngent in acting as ngent. on behalf of such gunrnutecing ngency, inclurling nimong such expenses, notwitlistnnding any other provision of $\ln n$. attornevs' fees and expenses of litiention.

(efc) All actions nnd operntions of surh.fiscal ngents under authority of or mursuant. to this section shall be subject to the supervision of the President. and to such regulntions as he unay prescribe; nnd the President is nuthorized to prescribe. either specifienlly or by maximum limits or otherwise, rntes of interest, gunmulee and commitment. fees, sind other chnraes which mny be mnde in comnection with lonns. discounts, adirnces, or coinmilments giaranteed by the minranteeing agencies through surh fis'nl agents. and to prescribe regulations goveining the forms and procedures (which sliall be uniform to the extent practicable) to be utilized in connection with such guarantees. 
(d) Ench gunrnnteeing apency is hereby authorized to use for the purynses of this section any funds which have herct ofore been approprinted or allocnled or which lereafter may be uppropriated or nllocoled to it, or which nre or inny lecome n vailable to it, for such purposes or for the murnose of iniertine the neressities of the nntional defense.

(e)(1)(A) Except as provided in subparagraph(B), the maximum ollightion of iny gurantceing afency under any lonn; discount, ndvance. or commilment. in coinnection therewith. entered into under this section sliall not. exceed $\$ 38,000,000$

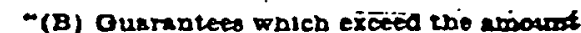
speciood la lubparagraph (A) mos be oDteres Into inder thits mection only if iso Committees on Armed bervices of the somate and the House of Representatives bavo boes notised in writing of such propored oblige-

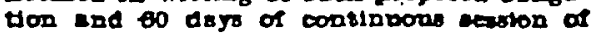
Congress beve explred fanowtog wo dato on whiteh sach wotkco was tranowedtitod-to wuch combinttees and Dettber Hoos of Congroes has adoptod Fithin such co-des period resolutaon aisapproptes such obligetton. Fior propoess of thls subparsigrapt, the contions ity of a mesulon of Congrese is broken only by in acjournmeat of the Congroes atne Mla iod the days on which eltber Bouse bo not In sosston bocause of an adjournoment of more unar 8 cayis to a dey certaln are axcladed is the comprotation of wieb so-das pertod.".

(2) The authority conferred by this section slinll not be used primarily to prevent. the financial insolvency or bankruptcy of any person, unless-

(A) the President certifies that the insolvency or bankruptcy would have a direct and substuntially adverse effect upon defense production; and

(B) a copy of such certification, together with a detailed justification therenf, is trnnsmitted to the Congress and to the Cominilfecs on Banking and Currency of the respective Houses at least (en) dnys prior to the cxercise of that authority for such use.

Sfc. 302. (50 U.S.C. App. 2092) To expedite production and deliveries or services to nid in carrying ont Govermment contincts for the procurement of mnterinls or. the performance of services for the nntionnl defense, the President may make provisions for lonns (including participations in, or guarantees of, lonns) to privnte business enterprises (including research corporntions not organized for profit) for the expansion of enpacity, the development of techuologrical processes, or the production of essential minterinls, including the exploration, development, and mining of strategic and critical metals and minernis, nnd munufacture of newsprint. Such loans may be mnde witliout regnrd to the limilations of existing law and on such terns nnd conditions as the President. deems necessnry. except that (1) financial ussistnnce may be extended only to the extent thint it is not otherwise ninilable on reasonable terms. and (2) no such lonn may be unnde in an amount in excess of $\$ 48,000,000$ mnless the Committees on Armed Services of the Senate and the House of Representntives have becen notifed in writing of such proposed loan nnd 60 dnys of contimuous session of Congress have expired following the: dnte on which such notice was transmitted to such C.mmitteps and neither. Iouse of Congress has adopted, within such 60-dny period, a resolution disapproving such lonn. For purposes of this section. the contimuity of $n$ session of Congress is broken only by an aljourmuent of the Congress sine die, nul the days on which either Ilouse is not in session brcause of nn ndjournment of more thnu 3 dnys to a dny certain gre exchuled in the computation of such fo-diny period.

SEC. 303. (50 U.S.C. A pp. 2093) (a) To nssist in carrying out the oljictives of this Act. the President mny make provision (1) for purchinses of or commitments to purchase metals, minerals, and other innterials, for Government use or resnle; and (2) for the cucoumgement of exploration, development, and mining of critirnl and strategic minerals, metals, matrenti: Provided, however. That purchnses for resnle under this subsection shall not include that part of the supply of nuy agri- 
cultural commodity which is domestically produced except insofar us such domestically produced supply may be purchnsed for resale for industrial uses or stockpiling, and no commodity purchused under this subsection slınll be sold at less than the established ceiling price for

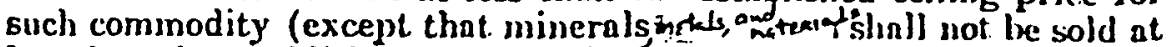
less than the established ceiling price, or the current domestic market price, whichever is lower) or if no ceiling price has becn established, the higher of the following: (i) The current domestic mn rkel price for such comnodity, or (ii) the ininimum sale price establislied for $\mathrm{Hgri-}$ cultural commodities owned or controlled by the (ommodity Credit Corporation as provided in section 407 of Public Law 439, 81st Congress: Provided further, hovever, That no purchuse or commitnent to purchaso any unported agriculturnl commodity shall be mnde calling for delivery more than one year after the expirntion of this Act.

(b) Subject to the limitations in subsection (a), purchnses and commitments to purchase und sales under such subsection may be mado without regard to the limitations of exisling law, for such quantities; and on such terms and conditions, including advance paysents, and for such periods, but not extending beyond Sertembia 30, 1995 as the President dcems neccssary, except that purchases or commitments to purchase involving higher than established ceiling prices (or if there be no established ceiling prices, currently prevailing market prices) or anticipnted loss on resale shall not bo made unless it is determined that supply of materinls could not be effectively increased at lower prices or on terms more favorable to the Government, or thut such purchases are necessary to ascure the availability to the United States of overseas supplies.

(c) If the President finds-

(1) that under generally fair and equitable ceiling prices for any raw or nonprocessed material, there will result a decrease in supplies from high-cost sources of such material, and that the continuation of such supplies is necessary to curry out the objectives of the Act; or

(2) that an increase in cost of transportation is temporary in character and threalens to impair maximum production or supply in any area at stable prices of any materials,

he may make provision for subsidy payments on any such domestically produced material other than an apricultural commodity in such amounts and in such innmer (including purchises of such material and its resnle at a loss without regard to the limitations of existing lav), and on such terms and conditions, as he determines to be necessnry to insure that. supplies from such high-cost sources are continued. or that maximum production or supply in such area at stable prices of such materials is niaintained, ns the case may be.

(d) The procurement. power granted to the President. hy this section shall include the power to transport and store and have processed and refined any mulerinls procured under this sectioun.

(e) When in his judgnent it will aid the national defense, the President is authorized to install additional equipment, facilitics, processes, or inprovements to plants, factories, and other industrial facilities owned by the United States Government, and to install Government owned exuipment in plants, factories, and other industrial facilities orned by privato persons. 
(f) Nolwithstanding nuly other provision of law to the contrary, mctuls, minerals, and materinls ucquired pursunt to the provisions of this section whijch, in the judgment of the J'resilent, a re excess to the needs of programs under this $\lambda \dot{c t}$, shall be transferred to the national slockipile cstnblished pursunnt to the Act of June 7, 1939, as amended (50 U.S.C. 98-98h), when the President decms such action to be in the public interest.

Tiansfers made pursunat to this subsection stinll be made without chnrge ngainst or reimbursement from funds avnilable under such act of $\mathrm{June} 7,1939$, as nmended, except that costs incident to such truns-i fer other thun acpuisition costs shall be paid or rcimbursed from such funds, and the acyuisition cosis of such metals, minernls, and materials trunsferred shall be deemed to be net. losses incurred by the transferring ngency and the notes payable issued to the Secretary of the Treasury representing the ainounts thereof shall be cnnceled. Upon the cancellation of any such uotes the aggregate amount of horrowing which mny be ontsinding at. any one time under section $304(\mathrm{~b})$ of this $\mathrm{Act}$, as nusended, shall be reduced in an amount egunl to the amount of uny notes so canceled.

(G). When in his judgment it will aid the national defense, the Pres ident may malse provicion for the developinent of sibstitutes for strategic nnd critical materinls.

SEC. 304. (50 U.S.C. $\Lambda$ pp. 2094) (a) For the purposes of sections 302 and 303 , the President is lieseby authorized to utilize sich existing departments, agencies, officinls, or corporations of the Government as he may decm appropriate, or to creale nerr agencies (other than corporations).

(b) The Secretary of the Treasury is anthorized and directed to cancel the outstanding balance of all unpaid notes issued to the Secretary of the Treasury pursuant to this section, logether with interest ncermed and unpail on such notes."

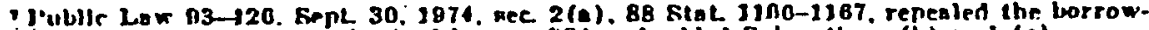

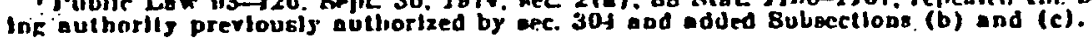

(c) Any cash bnlance remnining on June 30, 1974, in the borrowing nuthority previously authorized by this section, and any funds therenfter received on transactions heretofore or herea ficr eniered into pursunnt to sections 302 and 303 shall be covered into the Treasury as Iniscellaneous receipts.' See Sec, 7II

zoc. 805. (a) (1) (A) Bubject to mbeection tlanal deiense needs.

(k) (I). in order to encoarago and expedito the derelopment of syntbetic tual sor uso lor natlonal defense purposes, the Pxesldent utating the provisians of this Act (ather than vections $101(\mathrm{a}) .701(\mathrm{~b})$. 301.302 : 80s, and sog). And any orber applicable provislon of inw. whin tore immediste action to echleve production of synthetic fuel to meet no-

-(B) The President aball exerctse the -ov boitity granted by.this bectlan-

"(4) in convuration with the seciretary of Bnergs:

- (i) through the Department of Dafenge and any other Federnl department or engency dostgonced by the Presldent; and

(IIT) consisterit. with in orderly trandtan to the separate authordtes extabitihed.pur- 
- und to the Doled Btates Bribetce Fuel Corparatson Act of 1980.

- (2) Thls section sban not afeet tho wuthatity of the Unized Btetes Bjpebetic Inek Caporation

-(D) (I) (A) To asotht in carrjog out the objective of rblo section, the President. rub foct to subsections (c) and (d) ablll-(1) contract lor purcheses of. or camant meats to prochase. Iyntbotle fuel for Coparnment use for defenso neects:

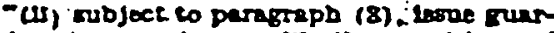
antees in pccoranece wtos the propintans of exction 301. except that the propitions of eoction $801(0) 11$ i(B) ann not apply with rospect to euch gunerates; end

(iil). ubbject to puragreph (al. mave lowe in accordance with the proviston of eoction 802. except that the provitans of soctlos 302(Z) sban not apply wirh respect to aued lains.

-(2) (A) Excopt as provided in subparasruph (B) sestetarice artbortred under this rubsection mey be provided only to persons Who arp partatpreting io a spathetic fuel project.

(B) For purposes of fabrtentlon or menulacture of eny component of a sprthette IUd profect assistance authortzed undar paragraph (I) U) (II) iba paragrash (1) (A) (III) way bo proviced to eny fubrtentor or mamufacturar of tuch companent.

(3) The Prosident may not utllige the autootty apder parngraph (I) to provide

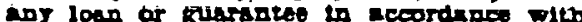
the profistons or. section 801 or noction 802 in amounts which exceed the limltatians establistied in wuch sectians unless the Pros secot onberits to the Congress notincacion of the proposed lown sor gunrantes in the mmer spectned under rection 307 and auch proposed uction is atther approved or not disepproved by the Congregs under ouch section. For purpases of section 807 . uny proposen pertalning to a propared loen ar guarnentee, notlce of whlch ts trancmitted to the congress under this pacagraph whell be conildered to be a synthotle sual ection. (c) (1) Bubject to puraprept (2). purchases und comodtments to purchare up. cer resbection (b) may be mado-

(A) Witbout regard to the limitntleane of oriting in lother then the lioultations contalned ir this Act) regarding tho pro curement of goods or nerrices by the Gopernmont; and

(B) ubject to soctlan $717(\mathrm{~s})$, tor and quantities, on wuch terms and conditions

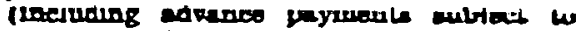
paragraph (B) L. and tor euch periods at the Prosident deem nocensar.

-(2) Purehnses or compoltments 20 pur-

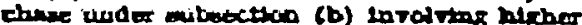
then estabinined colling prtase (or is there ero no ortablinhind enulag pucen currenty provalling market prices as determined by tho Bocreters of Bonergy) indll not be made unless it is determined that upplites of Tyntoretle ruel cauld not be encetinaly incroused at lower prices or on :terms mome Imvarable to the Goverament. or that cucb cocomitrmentes of purchnes are nocessary to acowre the avinbrity to the Ontted 8tates of suppltes overweas for use far an Ional defenso purposes.

73) Advence pryoents mis. not be made ander inls section noteco construction bas bepan on the aypthette ruel profect inraived on the Preatdent doternimes that in condstions procedent to construction hive been met.

(d) (I) zaceps as prontded in paragnep (2) aor purchese of co commitment to pur chase ijatbetic ivel nader onbaection (b)

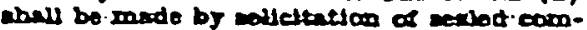
pettuvo blas.

-12) In ant case in arteh no ach bids are cubnitted to the Presdent or the Prealdent determine that no such bide thich beve been aubmitted to thi Preildert are scctint- ablo, tho President may pegotlato contrects for such purcheses and commltmedts to pur-

73) AD contrect for auch purcheses ar comontrmetre to purchesi sben provide enst tho Iresdant bas the stoht to remes aelip-

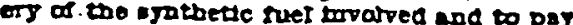
tho peroon lorotred in amornt ecan to the emoment by which tho prico tar exch grathetle IUt. as opectited to the comtract tivolved oxceode the market prtac, an ottermined by the Becrotary of Eners. for wer semede

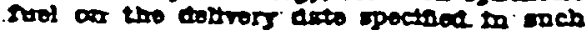
coment.

- (4) (A) (1) lima respece so my perrom, incivaleg an other perwon who is robution. chily cortroliod by weth persan' ies detar mined by tho Becrotary of eneron to PresLeenth rubject to rabpuragraph (A) (Al) mey not armard contracte for the purchnes of or commitmone to prothew moto than 200,000 berrele per daj coude on oquivalent of grothetto frol.

(ii) With respect to any person. metading apy otber person who is rutbotrutials controlled by such peroon (as determmed by the Berietary of Evetg\%): the Iretddent.ming not - ward ans contrnct for the purchase or commitment to purchses or frort then 78,000

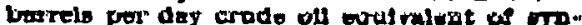
thetlc Ivel unless the Preddert movolits to the Congress nottention of sach proposed cobtruct of commitment-in the manot opectiled under ecction 807 and woch proposed cetion is otthet spproved or not dispproped b tho Oongrews roder such bection. Tror pur-

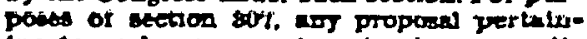
ing to such a proposed cortract of commitment, notico of which is trensmitted to the Congroes under enls mubptragraph, sball be constdered to be a mptbetic roal action

- (B) A contrnet tor the porchase of or commtrment to parabase oyotbetic rael may be entored bto only for ogrobetie foel which is produced in a syntbette fuel project which is located in the United Btates.

(C) Buch contract entered tnto inder this

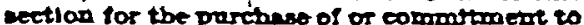
parctinse anthetle foel aban prowde that an parties to wreh oostract agree to roview sond to posably reoegottato soch contract withan 10 reare arter tbe date of the inttlal producton at the syotbetic ruol project intorted. At tbe the of wuch rever, the Prexdent aball deternatre the need for coptrmued n-

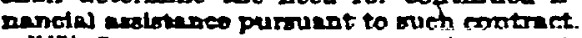

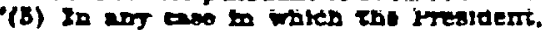
under the provistone of tbls bection. recepts

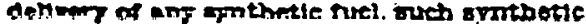
rull may be uned by in eppropmisto Tederal acrowes. ouch Toderal agenct ahall pay for cuen oy robethe raed the prevaltur morket

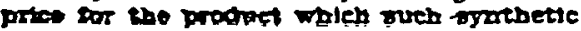
Iuel is replecing, as determined by the secrotary of Bnetro. from sums approprinted to

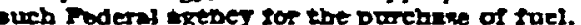
and the Preddeot ball pay. From grms appropitated for sock pupose porsund to the uthorleations contalned in sectroms $\mathrm{TI}(\mathrm{a})$

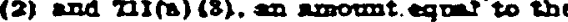

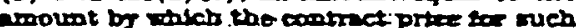

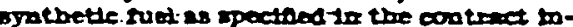
volved exceeds ach prewailn mintec price.

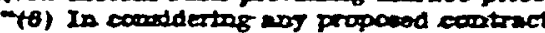
under thts eectlon, the Predident reall take

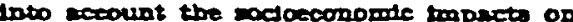
commuintles which would be affocted by any now ar expanded sactuties requtred sor the production of the spothetic. Iuel under wich contract

(t) The procurememt power pounted to the Presldent under this eection iball include the power to transport and etore and here proceseed and resined ang protuct procured under this section.

- (I) (1) No suthorte ponthined to the

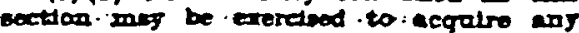

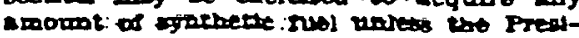
dent doterminas ibst exch cyntbetic fuel is neod to to mect nationsl defenes need end 
luel \&ill be resold by the Governome.

-(2) In apy case la wbleb sfatbetic fuel is acquired by the Coveramed under this nec thon such esptbitle fuel is no longer needed to meet national defebse needs end such - yntbotic suel to not accepted by a Foderal agoncy pursuant to ubsection (d) (b), the Presldent banll ofler sucb syotbetle ruel to tho Becretery of Eoergy for purposes of meetIng tho storago requirements of tho Btratoste Fotroloum Beservo.

"(8) Any Fotbetic. Suej which to sequlled by tho Covernment under this ection and which is not used by the Government or wo cepted by the Becretary of Exergy purounat to paragraph (2) whall bo sold in accordanco with applicablo roceral lev.

-(B) (I) Ang contract under thlo soctlan locluding any amendment or otber modiscation of such contract, whell rubjoct to th apallablity of uneocumbored appropriatlon in edpasce. spoctsy in dollars tho pardmum Lablity of the Federal Oovernment under -uch cantrect is dotermined in accordenco with peragreph (2).

"(2) For tho purpoce of dotermintog the maxtmum lebulty under any.contract under paragraph (1)-

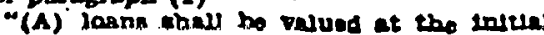
tace value of tho doan:

“(B) guarenters thell bo valued at the lattial inco value of such grarantoe (iscludIng any amount of loterest which is guaran tond under wuch guarantoe):

(C) purchase agreerrent shall be valued as of the axte of each auch contract based upan the Prosident's extunte of tho mextmum liebluty under men contract; and

"(D) eng increase in the llabllity of the covernment puraluant to any amendinent or other modiscation to a contract for a load. guarentes, or purchase agroesmnt shall bo valued in wocordanop with the applleable procoding subparapaph.

- (8) If moro thnn ano form of asalstace is providod ander this noction to ang 8 po thetle fuel project, then the mudionum. 118 . billty under enrh mntract lor purpones of paragraphs (1) and (2) aball be valued at tho mactmum potestin axposure on such projoct at any tume during the we of such project.

-(1) Any wuch contract wall be sccompraled by certiocetion by the Director of the Ofloc of Managemant and Budget that the nocesoary appropristions hive been made for the purpose of such castract and an vallable. Tno remetalog eralleblo and utapcumberod.Appropristlons whell oqual the total ABgregate appropriaslons leas tho aptro geto martionum liabllity of the Proderal Gopermont under all contract pureuant to this nection.

(6) Any comonlement medo under thlo section which is nullised or volded lor an reason shall not be copsldered in the apgrogato marlonum timbllity for the purposes of paragtaph (4).

(D) Por purposes of bectian .102(2) (C) or the Natlonal Eavironmental Polley Act of providing any lasa, gunanoteo, or puretenso gereement under thls eection shall be deem. ed to be a major Pederal action agholocantly afecting the qunilty of the buran evirapment.

-(1) All lebarers and mechanles emploged Sor the constructon. ropalt. or alterstlos of ang oysthotic ivel project runded, in wholo or la part, by a grurantec or losp anterea lato pursuant to this sectlon thall be pald wapto at rates not less than thooe prevalling an profects of a dimilini cbnracter is the locallity as dotermalned by the Becretery of Labor in accordance . with the Act entitied An ACt Relating to the rato of wapes lor libbares ind mechanica employed an publle bullaling of tbo Dnited Btates and the pirtrict of . - jumbir by contractors and ubeontractare.
2891 (40 O.s.C. 2706 et req.) end combonody

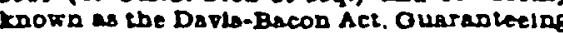
pencles ball not extond guaranters and the Preslaent sball dor maxe loans for the conitruction. repals or zueralion of any opnthetle fuel project ublews a certiscation th proplded to the agoncy or the President, as tho cese masy be, prior to the commencoment of construction or at the time of allag an appllestlon for \& lorn or guarantoo, If construoWon bes alreaty commencod. that these labor rendarde will bo meintalood at the aynthetsc. Iuel project. Whth respoct to tho isbor tandand opocined in thls subsection, tho Becretary of Labor whall have tho sutborlty and functions eet Iorth itn Boorgralestlod Plan Numbered 24 of 1050 and noction 278 (c) of tstio 40.

(U) (1) Nothlag in thile noction hall-

(A) Afoct the furtsdiction as tho Btates and the Onftod Btstos oper vaters of $\mathrm{mog}$ - itreaso or over any ground prater rosource:

(B) alter, amend. repeal, Lntorpret. miodl25. or bo is conflet with ang interstats compact made by any Btates; or

(c) confer upon iny non-Federal entity the ablitity to exercibe any Paderal stght to the waters of any otream or to any ground Tater resource.

- (2) No ejatbotscituel projoct constructed pursuant to the authorities of thls section mall be-conslderod to be a Federnl project for purposes of the applaction for or abdignmant of water ragbte.

- (k) (1) Bubject to paragraph (2), tho authortity of the Presldent to ontar into any new contruct or commitment under thels secUlon shall cosse to bo oflectloe on tho dsto on which the Prealdent determines that the Dnited 8tstes Bynthetse Fuels Oorparation 18 establisbed and fully operational conadrtant wteb the provtslons of the Onltod BLates Bgnthetse Puels Corporation Aet of 1080.

-(2) Contracts entered into undor the section before the date speciod in para. graph (1) inny be renewed and axtunded by the President aitter the date speclned in parakrapb (2) but only to trie ertent that. conn. gress bas specincally eppropristed tunds for such renewals and extensions

"Bec. 900: (A) (1) At any time after the date of the enactment of this roction, the Presldent may. subject to paragrapb (2). Inpoke the suthoritles provided under this section upon maklag all the following determastlans and tranomitting a report to the Cangreas regarding such determinations:

-(A) a netlonal energy supply chortege bas resulied or is ively io result in a abort2all of petroleum supplies in Eoe Initod Bratas and such abortage is axpected to peratst 10 a perlod of -time ramclent to sertoutsly threaten the adequacy of defense trel supplies essentlal to direct defenso and direct defense industrial base programs:

(B) the contloued acequacy of buch cupplles cannot be assured und requires oxpedited production of eynthetic fuel to pro Fide such defense fuel supplles:

(C) tho expedited production of syathette foel to provido such defanso sual supplies will not bo eccomplished is a timoly manner by the Dnltod Btateo eyathotsc Puels Corporation; and

(D) the exeretive of the suthartes proFded wnder oubuection (c) is neceesenty to provide sor the expedited production of grothetlo suial to provido euch dafonse sual supplies

-(2)(A) Aoy tranomittal under paracrapt. (1) shall cantatn a dotermination by two Predident regarding the oxtent of tho antjespated sbaitage of potroleum enpplies. If - tho - Prectaent dotormines ' that such ahortapo is greater then 25 percent. the authartles invoked by the Preaddent undes thls sectlon shall bo efrectivo:on tho date on whlch the roport requirod ander para Eraph (1) is trananittod to the Carigrosi. 
(B) If the President doteronloes that sucb ahorrage is less thad 25 percent. the transmited under parastaph (1) shall be mede in accordance with section 807 and tho autborities under thls ection abell be eflective onls we propided under such eectlon. For purposes of sectlon 307. spy detarminstlon to lavoke eutborltie under this eection notlo of which is stansmittod to the Oongress under this subsection, wall be conaldesed to bo a igathetle sual sction.

$\rightarrow(8)$. No court whill bave the autbotsty to reviev any determalastion - mede by the Prestatent ander this rubsectlon.

$:=(b)(1)$ (A). Bubject : to : the requirements of subection (A). in order. to encourage and expedite tho developmont of mpthetlo rual for wes for nationel defonse purposes, the Preadent. utllifing the propinton of this Act (other. than - ectlon 104(t), 101 (b). 801, 802, 809, end 808). and any olber applicable proviaion of Isw, abnll take im medlste actian to achlevo production a eypthetio Iual to meat nittonal defense noeds.

"(B) The President alsy exerche tho av. thority printed by this exctlon-

"(l) in copourtotion. Fith the Bacretary of Energy: and

:'(II) thuubl tho Dopertmeat of Mafenn and on ofher Poderal department of agency designated by tho Prealdent.

(2) Thal wetion aboll not aflect the nuthortty of the valted Btites Bjatbetio ruelis Colporston.

-(C) (1) (A) To assiot in eartying out the objectives of tinis sectlon. live President subject to subsocttons (d) and (o), abnll-

(1) cantreot lor -purchases of or com mitments to purchass syothetle fuel for Coremment noo for aefense needs;

(11) rubjeot to paragraph (4), lasue gitse intees in cocordanoe with the provislons af ection 801. except that tho propiaton of coction 801 (0) (1) (B) andul not epply with copect io mach gusinstecs:

(iii). wubject to -paramiaph (1), make loans in ecordance whe the provlstanis of section 802, except that the provialon af cection 802 (2) aball not apply. with respect to ruch losin:

(1r) have the sutbotity to roqutro tuel cupplier to provide mothetic tuel in anj cavo in wbich rov Fralued decm is preo-

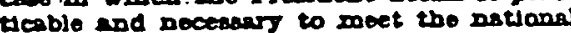
dafenso noods of the Inted Btates. Nothtar In this paracaph ibvi be intendal to pro Tde authorlty lar the Preaddent to requlr Iusl xunplifere to produce syptbetic-2uel if Iuch uppuen aro not uready. productus ouch supplian aro not already produclag gothetse ruel:

(1) bre the autborth to install addi-

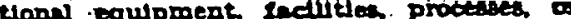
to plostes and other

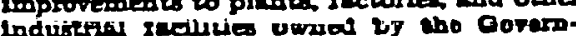

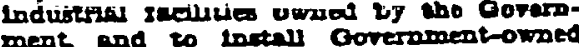
meat and to intall Government-ownte

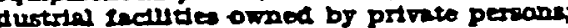
anst

(v) - bre the authordt to indertake coverament mplnetto subl projocts in ac cordance with the provistons of paragraph (2).

(B) (1) secept is provided in elnuse (4)

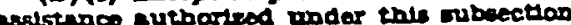
may be provided only to persans spho are partadpatiog to a antherte tuel projoct.

(14) lor purposes of setorication ar manu Inctiro of any companent of a opptbetic tuel profect. assistance suthorzed nnder pargeraph (1) (A) (II) and parroaph (I) (A) (14) iney bo provided to any fabrictior of mannfectures of unch componemt.

(2) (A) The Covernment, ecting through the Prestant is authortzed to own Gavernment sythettc ruel profects. In any case in Tblob the Coverament owas a Goverament oynthetdo ruel project tho Government shall cantract for the convinuctian ind operatian or auch project.
(B) The euthonts of tho Goverament pursuant to subparafrapb (A) to orro and contract lor the coneructlon and operatlon of any Covernment esptbotic itued project hall include, among other things, the auchortis to-

"(l) subject to subparagraph (C). take dolivery of synthetlc Inel. Irom such project:

(11) trabsport und store and bave processed and refined such ognthetle luel.

(C) Ang egretheto fud whlç the Covernmeat take delf very of Irom a Coverament synthetle fuel profoct aball bo disposed of in accordance Fith subsection $(g)$

“(D) To the maximum extent teaslble, the Presldent ahell utilles tho private sector. the activities asocisted onth thls paragraph.

(3)(A) Except an providod in subpara. Rrapb (B). anj contrect for the constructlan or operation of a Covernment egpthettc fuel project shall be made by callicitation of seajed competituve bld.

-(B) In any caso in which no such bjas are subbits to tho Congress notlecation of the determines that no such blds here been submitted wblcb are accepteble to the Prosident, the Presddent may negotlate contracts ilor uch construction end operation.

-(4) The Preaifient meg nnt mtiltze the autbority under paragraph (1) to provide an lann or guirantee in accordnace with the proplstons of section 801 or aectloo 802 : In mounts which eroed the limitiotions establikhet in such section. unien thp President rubmits to the Conpross notiscation of the proposed lonn or guarantes in the manas opezaed under section 807 and such proposed action is elther approved or not disapproved by the Congress under such section. Por purposes of section 307, eny proposel pertalatag to a proposed lonin or guarantec. notfee of whteh is tranimltted to the Congrens undir thls puragraph, sball be conslaered to be a synthetic fuel action.

- (5) Before the President may utulze any sectic authorlty described under: paragraph (1). the President shail transmit to the Congress a statoment copteining a certincstion that the determioations made by the Fresident in the transmittal to ine Congress under subsection (a) (I) ere tull valio at vae time of the trankmittal of sucb ceruneatwis.

- (B) (A) No eutbortty contained in paregraph: (1) (A) (1) Ebrougb (1) (A) (1V) may be uruised by the Fresldent uuleas the use of such autbortty bus been authorlzed by the Copgros: in an set herelonster enacted by the Confress.

-(B) The Presldent mag not vilise eny uthortty under puragrapl' (1)(A) (v) or paragraph (1)(A)(VI) xunless the proposed exerelse of euthorty has been opectheally athorted an a project-by-project breds in no act herolowiver enucted by the congreas and Iands bive been spectheally approprt. ated by the Congreas for purposes of exerctcting such authorlty.

"(d) (1) subject to parasraph (2). purchases and commitments to purchase under cubsection (c) may be made-

(A) Fithout regard to the limititions of erleting atw (other than thase limititlons contalned in this thet) regarding the procurement of goods or services by the Oopermment: and

-(B) subject to rectlon $717(\mathrm{a})$. Jor such qunotitles, on weh terims and conditlons (lincluding edrance parments subject to paragraph (3) ). and -Ior ruch perlods is the President deems necessary.

(2) Purchnses or commituents to purchase under aubsection (c) involoting higher than estublishod celling prices (or if there are no ertabllabod celling prices, ourrently prevalling merket prices as determined by

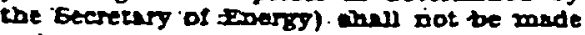
unless it is determined that oupplies of oynthetic fual could not be effectively lincreased 
to the Government, of thet such commit. ments or purchses are recessary to susure the evallabilty to the Dnded States of supplles oversens for wso for Datlonal delense purposes.

"(3) Advance pasments mog not be made under this section unless construction has begun on the s gnthetic tuel project involved or. tbe Eresldent determalnes that all condlilons procodent to construction havo been met.

"(e) (1) Except a provided in paragraph (2). ang. purchase or commitment to pur chase sprithelle fuol under subsection. (c) sball be made by sollcitation of eesled competitlve blas.

- (2) In abj case-In which no such bids are rubmitted to tho President or the President determines that no auch blds whicb hape been submitiod to the .Prasident are acceptable. tbe President may nogotlate tracts for such purcbares and combaltments to purchase.

(3) Ang contract lar soeh purchases or commitments to purchase sball provide that the President has the righit so retuse delivery of the symtbetic fuel lavolved and to pay the person involved an amount equal to the perover by phich the prtce 8 or such $8 \mathrm{ym}$ thetic ruel. as epeclfed in the contract in. volved. exceeds the market price. as determined by the Secretary of Energy, for such syathetle Iuel on the dellvery date speclaed in such contract.

(14) (A) With respect to any person. including any other person who is substantially controlled by such person (as determined by the Becretary of Energyl. the President, cubject to suparagraph (B), may not award contracts for the purchace of or commitment to purchnse more than 200,000 barrels per day crude oll equivalent of ayathetic Iuel.

-(B) With respect to ang person. IncludIng any other percon - who is substantially controlled by such person (as -determlned by the Becretary, of Energy). the Presldent rany not award any contract for the purcbase of or commitment to purchase more than 75.000 bartels per day crude oll equiv. slent of s50thetic tuel unless. the President submits to the Congress notification of sucb propased contract or commitment in the manner specteled under sectlon 907 and such proposed actlon 2s eltber spproved or not disapproved by the congress under auch bection. For purposes of vection 307. noy proposal pertalntag to such a propoeed contract or commitment. notice of which is transmitted to the Congress under this subparagraph. sball be considered to be aypthetic suel metton.

(b) A contract lor the parchase of or commitment to purchese sypthetic fuel mey be entered into only for synthetle Iuel which is produced in ayplbetic fuel project which is located in the Unlied States.

(18) Euch contruct entered into under this section lor the purchase of or commlt ment to purchase eynthotle ruel shall provide that ill purties to such contract abree to review and to passibly renegotinte such contract within 10 yenrs aster the dste: of tbe toltin production at the spribetic fuel pro;ect involved. At the thme of such review. the Presldert aball determbe the nood for contmuta anancial assistance pursuant to ouch contract.

"(7) In ang ense in whlch the President, under the provtslons of thls sectlan, sccepts dielivery of any synthetle fuel such oynthotic fuel may. be rsed by ab.eppropriate Federal agency: Buch Federal ngeney bhall pay for such oyntbottc ruel the prevalling market price ior the product whlch ouch synthetlo fuel is repleclog. as determined by tho becretary of zenerg: trom nums appropilsted to ach Pederal egencs. 10 r tho. purchase of fuel, and the Prealdent abill piry, trom -uss вpproprievea lar such purpase. an amount equal to the amount by malch the contract price for uct sjpthetle tuel us epecined in the contract involpod exceeds auch prevalliag market prtce.

(8) In considertng any proposed contract under this sectlon. the Presldent-shall taks toto ccount the socloeconomic impacts on communitles which would be arlocted by any new or expanded facllities roqulted for the production of the spthotle fuel under such contract.

(I) The procurement power granked to the Prasident under this cection ahall include tbe power.to thnoport. ind etore and bave, processed -and-reanod any iproauct procured under this rection.

(B) (1) No euthorits coptalned in iblo sestion may be exercisod to sequiro ang emount of egnthetic furl unless tho President determines thet such opathetle fuel is needed iso meet national defenso needs and that it is not antletpated thet euch yinthetle fuel will be resold by the Ooyermuent.

(2) In ang case in which genthetlo fuel 1. sequired by tho Government under this section. such yotbetle fuel is no langer needed to meet national defense peeds, and audh byithetlc luel is not nccepted by Federal agency - pursuant to absoction (o) (7). the President aball oner wuch oynthetic Iuel to the Becrotery of Energy Ior purposes of meeting the storage requiremente of the Strategle Potroleum Reserve.

"(8) Ang spotbetle fuel which is soquirod by the Goveroment under this vection and which is not ued by the Covernment of accepted by the Becretary of Energy purav. ant to paragraph (2), eball be cold in accordance with applicable Pederal law.

(b) (1) Any contract under thi sectlon. including any mendenent or other modiscation of buch .contract. aball subject to the avallablity of unencumbered approprtsthon in indrance. spectry in dollars the controum .llabllty of tho Paderal Covernment under such contract es determined in sccordance with paragraph (2).

$\because$ (2) Por itbe purpose of determlating the madimum uabllity under.ung contract under paragraph (2)

-(A) loanx aball be balued at tho triltid Iace value of the loan:

"(B) guarantees aball be ralued at the Initial lace value of ruch- guarantes (tocluding any amount of interest whteh it guaranteed under much grurantee):

"(C) plurchase asteements hall be valned is of the Ante of weh wuch contract based upon. the Prealdent's - etimnte of tho maxlmus libblity wher weh contract:

"(D) contracts 10 r ectifities under subsection $(C)(1)(A)(P)$ shan be velued at the infisi face value of such contract:

(IE) Corerament synthetic ruel project pursunet to zubsection (c)(I) (A) (vi) abvill bo valued th the current estimsted coot to the Government, as determined annualy by the Prasident: and

(F) Ang Increase in the isbulty of the Covernment pursuant to eny nmindment or other moditecation to a contract for. a losn. gunrastee. purchsie apreemont, contract for actifities under subsection (c) (1)(A) (V), 0 - Copernment syathetie fuel project purvuns so subsection - (c) (L).(A) (A) .envill be . valued in accordanco with tho epplicable precedeng eubparagraph.

(3) 18 more than are form of asalstance is provided under this extion to eny aynthetlo fuel project then the maxlmum in bluty under such contract for puposes of paragraphs (1) and (2) ahall be valued at the maximum potential exposuro on ouch prolect at ang time durtag the life of such pros$\infty$ ot.

(1) Any wueh comtract abnll bo -nocamparled by a cartification by the Director of the Omce of Mungeriont and Budget thet 
Lat lat purpore as aucb consent and aro arallable. The remutatig arallable and umancumberot appropstatroms absll equal tho Lotal asgregate approptetion hes the as-

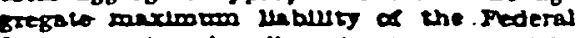
corerament boder all contaces punzunat to thls sectron.

(S) An coction which is nullued or valded soc ary

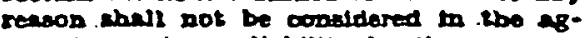
gregate marlmum liablilty for the purposes of paragraph (4).

(1) For porposes of coction 200 (2) (C) of the Natlonin Eavinommextal Pollt Aet of 1889 (42) D.8.C $2302(2)$ (C) ). 200 action is provlding ang boen, gurronted. of purchase

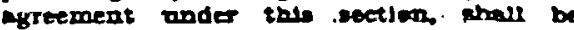

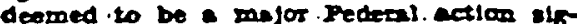
nlacantly afrecing: the qualts of the humar anviranmont.

(1) All inborers ad mechernice employed for the corratruetion, ropulr, or Aterestion as an orpthetle trul profect funded. In whole or in part, by guaranteo or lowe antered lnto pursument to this sectloir chell

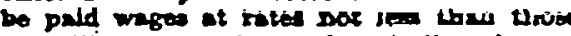
prevauting on profects of a Imthe charace wer in the localit as determined by the Bocretary of LAOr in mecurinace - 1 lib tha $A$ of entitied : "Al Aet rolateng to the sete of wage ico liborers end mechentes employed an publle bulloungs of the Dalted Gtate and the Distrlet of Columbin by contrector

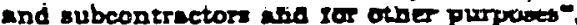

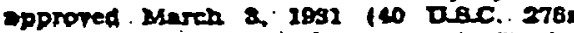
or eq-1 and commonly brows as the bathBacon Act Ouranteetng agenctes tanll not artend guarantes and the President absl

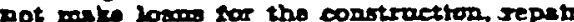
or Altentian of ang apsthotde tuel project unless a certifation ts protided to the apercy or the Erestdent. as the case ming be. podor to the comomencement of construetson or at the time of allag an application 105

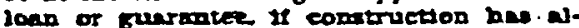
rood commonced. Lhat theos labor stanoard will bo melatedned at the cyotbettc tuel project. With respect to the labor utabdaras spocised in this oubeection : the becretary of Labor wall have the althorler and sanctlons set forth in Reorganisation Plan Numhared 14 of 1950 and sectior $270(e)$ of title 40.

(k) (I) Notheng in the section sball-(A) - neme the jurisoliction of the Btsteo and the Dntted Btutes oper weters of any - Tream or orer bog tround mer resoraroe.

-(B) alter. Aroesd, tepoes, interpret. moats. or be is conelet ofth ong toterstate coin patet mude by ans Btate- or

(c) confer upon any non-pedersl entry

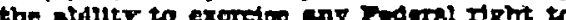

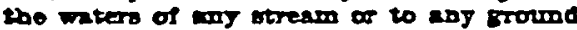
water resolims.

-(2) No - Esatbetic rol profect tracted provelust to the entbontles or this cection arnill be comatdered to be il Pederal project Ior proposes of the application tor or assigament of water rigkta.

- (1) renewalo and extenstoss of con-

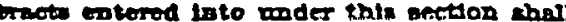
bo mede only to the extent that Consress has upectifcally approprinted fonds lor euch renewhe and extenstoms, untess the prestdent certiace that tbe deterrilnations wa. der mection 200 (a) (1) remaln in effect 10 r pruposes of the we of meb enchosts.

\section{$100 \pi$}

Bxc. 106. Begtoulng one year aftor tho of fectspe date of this part, and andually thereIfter. the President shall submit a report to the Congress on actlans taken under sectlons 305 and 308 of. The Defense Produetion Act of 2850 .

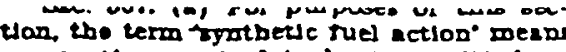
any motter roquired to be transonitted. or ubmitted to the Congress in sccordance Filb ebe procedures of this section.

-(b) Tho Preslatent abell trabsalt any - frathettc ruel setton bearing an ldentiocs. tran number) to bots \#loases of the $\infty$ D greas on the samb dey. If both Bouses ate not in intalan on the ong on whteh eny apothetse roed action is rocetrod by tbo ap

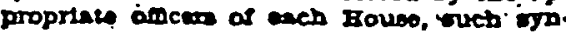

thetso toll metian wall bo deemed to have

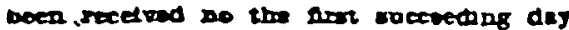
on -bleb botb Holves are in estan

-(e)(1) Ireopt as provided in paragrapb

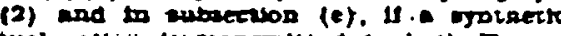
tuel action is'-zranomitled to both Fonse

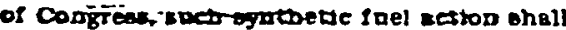
Who.efrect it the ond of the trot pertod of

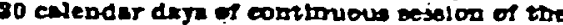
congress arter the dat on whteb oures ogn-

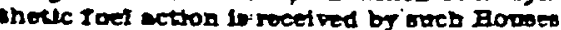
unless between. the dere on whlch such spe-

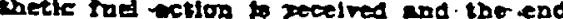

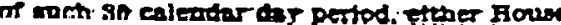

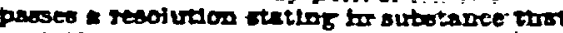

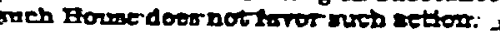

"12) A orathelto fuel ection velesermed to partegrapts (t) mor tele elect pitor oo the expiratton of the .80-alendar-disy pertod efter the dete on wheh sures ection is reetved. t5 each Houre of congress approves - remintton emmativery shathr on substance that Butr House does not object to buch - ynthetic suel action. Except as provided to sabsection (e). In smy ouch case. such ogathetic tuel actlon hill rake effect on the dete on wated emen resolurion is approred.

(d) For parposes of subsectiop (c) -

- (1) cortinulty or resstion is braken onlr by an adjourineat of the Congress stue die: and

-(2) the days on which efther Bouse in not in resston beckuse of an idfourmonent of more shan 8 dass to a day certaln ure ex cluded in the computation of the 30-calen. dar-day petiod.

-(e) ypder provistons contalaed in in synthettc siel setion, aing provision of such syp. thetic forel wetlon may tare effect on a data Inter than the date on which sach erathetic rool cotion otherwise woula tate ef fect, If such action is nat otsapproved, pursuratt to the proplstonsor this section.

(I) This stcilfien is enneted by the Oan. Brese-

-Ti) as at exerclse of the rulemaktar power of the Bennite and the Honse ar kepre. extatives, reopecthery. and as such it th decrned a part of the rules of exch House. respectively, bur appricable only with respect to the procecurre to be Iollowed in zbai Hause in the case of resolntions-described by sub. section $(B)$ of this section. and $\pi$ orperbades otber rules only to the extent tabs it is toconststent with such rules; and

-(2) Wth In recognituon of the constltutonal rtght of elther House to change the rolas (s0 for as boef relate to the procedure of that Hoose) at ang time. in the same maner and w the axime exterit as in the crose of 30 J onter rme of the Bouse.

-(B) (1) For parposes of subsection (b) the terme resolution' means \& resolution of efther. Hoives of the Congress described to paragraph (2) ar parapraph (3).

(I) A resolutson - tbo motter atre the resolving clatue of wibh is as tallenes. "That the coes not ablect to the syathetre fuel setion numbered

cetved oy the Congress on 19 . the best blanx sproce thereln belog mied orith the pame of the resolving Boure and the other blant apaces belog appropitetely alled. ADY sach reolution ing anly cantaln. refereace to one spnthetla fuel action. 
resolfiof clause of Fblch is as fallows: "That the does not inpor the syotbetle fuel actlon numbered recelved by the Congress on $\quad 10 \therefore$ the orst blank oprec theretn betng anod with tbe name of the resotving House and the other blank opaces tbereln betog approprlately alled Any rach resolution may only can. isto - referesco to opo uspthetle sub action.

-(4) A resolution once introductd orith respect to a oyuthetle riel sction mball im medistefy be referred to a committeo (end -1I resoluttonn with respect to the same iyp-

thetlc tuel action mall be mierred to the came commlttel to the proddent of the Benate or to Bpeares of tre Bonse of Repsosemtetives, so the case masy bo.

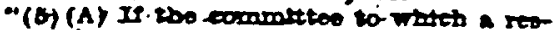
olution plth respect to aydthetle - torel action has boen referrod bas not ropdrted It at wo ond of ' 20 eabendxo days after it was rectived by the Boure 10volved, it absh

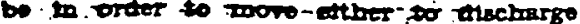

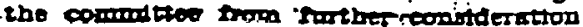

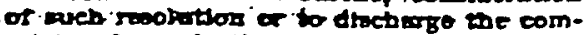

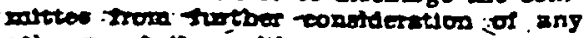

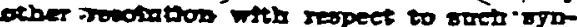
thetle fuel sctian wotes has been reterred 50 the coinmtitios.

r. (B) A motion to discturge megy be made oaly by an indricand forutar the resolv2ton, absll bo logtol pituleged rexcept that it may not bo mado ptor tro commitee has reported a woolution with respoct to tho

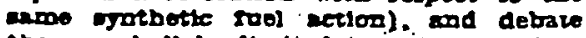
2hereon sball bo lloilted to. not mare than one hour, to be divided oquens between those fovorts and those opposdng the resoYrituon. An omebcont to the motion shall not be to order, and it sban not be in arder to move to reconildet the voto by whlch the motlun wis agroed to. or distagneed to

$:-$ ic) If the moston to discharge 1 s agreed to or disagreed to; the mothon may not be renewed, nor unis notber motion.to dischirge the committee be made with respert in ong ther resolutton with respect to the came oyntbetle tuel actrom.

"(6) (A) When the committee bas reparted for has been ollesarget from rurther conctderation on = resolution, in shall be.al eny troe thereaster to order (even though a preWows mothon to the uxene -errect. has been oricharged to) to move to groceed to the consideration of the resorutron tre motlon chall be rights privieged aurd sall not be debatable. An aroertiment to tho inotion chell not be in order, and it torall not be in order : 20 move to reoundder the vote by walch the motion was agreed to or dusagreed to.

-(B) Debste or the resotution refersed to

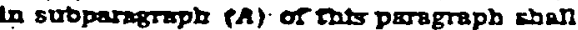
be 21 mited so pot wore enam s nours, waich wall bo dirted equall - between triose favor-

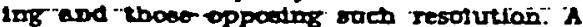
motion further to llmalt debste shah nal be debatsble. An nomencent to, or motson to der, and $t$ in end not be in order to move to recoinstider the wote by which such resolytwoo was agroed to or dirogreed to, except thoo Was Egrod to or

chat it shall be in orderof a subetitrate, acendereng at the tert of the

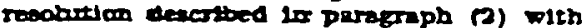
respect to a mothete roel sethon. ror a resclution dencabed in permgrapt p if with re. spect to the secos ngerbetre foet action: or

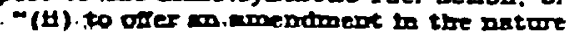

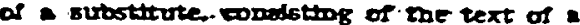
resolution described in parasmop (J) with

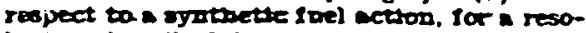
lution described to paragraph (2) With respect to the mame soch syothet fe furel action.

"(C) The ancoutments described in clisuses (1) and (HI) of mubparagrops (B) atwill not be amendable and sherr be debstable nader the s-minute tare in the House of Representatives by the offering of pro rome ameodmezin. spect to the discherge trom coranittee or the consuderatrom or a resolutuon-and motions to proceed to the wonsteration of other bustness. shall bo doclded Nibout debste.

"(B) Apperals Irom the dectsion of the Cholr relsung to the opplisentron of the rutes of the Senste or the House of Representetives, as the case way be, to the procedure

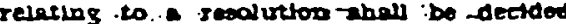
Whouldobet.

:(8) Potwithistanding ary ces the provistons of this subsection. If a House has spproved - resolution with respect to a synthetle tuel action, then- motion to rocommit shall not be in order nor ahell tt be in order to convider in thet Bouse ang othor resolutlon with respect to the beme eypthetle tuel ection.

"Brc. 808. (a) Por-pirposes of this Act the term "Government synthetlc fuel project' means syothetic luel profect undertsken in accordance. with the propldions of extlon $306(c)$.

(b) (1) (A) Por purposes of thls Act; the term syathetic fuel' means any wolld. Ilquild or tas, or camblatulon-thoreof. Which can be used as a substitute for petroleum or naturat ges (or any derivattres thereor, including chemical leedstocks) and which is prodinmen by chemleal : or physical .. transformation tother then wasblog. coklng. Or desulfurte(ng) :of domestic sources of -

: :(l) -coal, trcluang ligalte and peat;

(Ii) unale;

: (III) tar sands, IDcluding those bearg oll ources whero-

*(I) tho cost and the technical and tcopomfe rtske make extraction and processing of a bespy oll resource uneconomical under applicable pricing and tax polletes; and

(II) the costs and riske ero comparable to those asoctated with sbale. Conl, and Zar sand resources (other than heavy oli) quallfying for assletance under section $\$ 05$ or section 308: and

- (Iv)-water, as a source of bydrogen on) through electrolysis.

- (B) Ruch term includes mixtures of con and combustiblo Hqutds, including petro leum.

(C) Buch term does not include Bollds. Itquids, or guses, or comblastions thereof derived from blomass. whlch includes timber. cnimal and timber paste. municlpal and industral waste. sewage, sludge, oceanic and terrestrial planes, end other organde mntter.

- (2) (A) Por purposes of this Act, the term "ronthetie -luel profoct" means any -Jacluity ucing an integrated process or processes at a specine geographle location in the United States lor the purpose of commerclal production of vyathetlo tuel. The project may include only-

(1) the facilit5. Inclualos the equipment. plent. machinery. supplies, and otber materials assoctated with tbe lacllity. which conTerts the domestlc resource to syatbetic fuel

(II) the land and minersl rgbta regutred arectly for use in cannection with the iecllitica for the production of sypthetic Tuels:

-(1ii) ing facllity or equipment to be naed in the extrection of minerel for wise directy and exclustiely' in such conversion: (I) whlab-

- (as) is co-located with the converalon faclltry or 10 loceted in the fromediste tednity of the cosverdion Iecllity, or

(bb) If not co-bocated co located in the inmediate vicintiy. in Inctdental to the project lexcept in the event. of a conl mine wbert no other reasonnble source of conl is avallable to.the project): innd

(II) which is necessary to :the project and

(Iv) ang transportation Iacluty. electric powerplant, electric tranxmasion ine .or other lacllity

(I) wbich in for the erclusive use of the project: and 
except that transportstion racilltits used to transport syothetic fuel iway irom the project shall bo uBed exclualpely to transport spatbetle fued to starafe. Tacllity or.plpe Ilno connocting to an exlsting plpeline or procescing secllity or ares within close proximity of the profect.

$\because$ (B) (1) Buch torm may also include A profoct whlch will result in the replacement of a ifplecant amount of oil and ib-

- (I) used-alels tor the production of mixturo of conl and comburtible liquids, locluatos petroleum lor direct uso as Iuel, but phall not includo-

(a) any mineral rlgbt: or

(bb) eny facluty or equipment sor extraction of any minera:

(III) used solely for the commerclal production of hydrogen from writer through electrolyato; and

$\because$ (III) = magnotohydrodynaric topplng cycle used polely for the commentel produotion of electrictity. magnetobydrodspamle technology ahell ofl bo ellgube for guarantes under section 805 or extion 806.

- (C) Far purposes of thls peragrapb-

- (1) the term 'exclusitre' means for the alo use of the project, except. that an inc|dental by-product might be used for otber purposes:

-:":(4) .the term .inctdental means a relo tipely amall portion of the cotal project cost: and

"(Ui) the term inecessary means an integrated part of the profect takiog into to count conslderations of cconomy and efl clency of operation.

(1C) For purposes of sectlon 805 and soc t1on 306 , the term 'United States' means the several Btates, the District of Calumbla, the Commonwealth of Puerto Rlo . Ounm, the Virgin Iulands, the Nortbern Martan Islands; the Trust Tertitory of the Pactec Iolands, and any other territory or possession of the . Daited Btates.-

SEc. 702. (50 U.S.C. App. 2152) As used in this Act-

(a) The word "person" includes an individunl, corporation, partnership, association, or any other organized group of persons, or legal successor or representative of the foregoing, and includes the United States or any agency thereof, or any other government, or any of its political subdivisions, or any agency of any of the foregoing: Provided, That no punishment provided by this Act slubll apply to the United States, or to any sucli government, political subdivision, or government agency.

(b) The word "materials" shall include raw mnterials, articles, commodities, products, supplies, components, technical information, and processes.

(c). The word "facilities" shall not include farms, churches or other places of worship, or private dwelling houses.

(d) The term "national defense" means prograns for military nnd atumic cnergy production or construction, military assistance to any foreign nation, stockpiling, space, and directly related activity.

(e) The words "wages, snlaries, and other compensation". shall include all forms of remuneration to employees by their employers for personal services, including, lut not limited to, vacntion and holiday payments, night shift. nud oller bonuses, incentive payments, your-enil honuses, employer contributions to or payments of insurance or welfare benefits, einployer contributions to a pension fund or anmuity, payments in kind, and premium overtime payments.

(f) The term "dcfense contractor" means any person who enters into a contract with the United States for the production of material or the performance of services for the nntional defense. 
Src. 711. (50 U.S.C. App. 2161) (n) (1) Except as provided

in paragraph (2), there nre hereby authorized to the npproprinted such sums as may bo necessary und nppropriate for lin carrying out of the provisions and purpases of this Act. includinar sections 302 and 303 and for pryment of interest. under subsection (b) of this section. , but excluding sections 305 and 306

fby the President and such ngencies ns he may designnte or create. Funds mude available/

pursuant to this paragraph; for the purposes of this Act mny be allocaled or transferred for any of the purposes of this Act, with the npproval of tho Burenu of the Budget, to nny ngency designated to nssist. in carrying out this Act. Funds so nllocnled or transferred shalf remnin nvailnblo for such period as mny be specified in the Acts mnking such funds avrilable.

(b) Interest. shall accric on (1) the cumnlative amount of disburspments to carry out. the purposes of sections 302 nnd 303 (except for slornge, maintennuce. and other operating and adininistrative expenses), plus any unpaid accrued interest, less the cumulative amount. of any funds receired on trnnsictions entered into pursuant to sections 302 and 303 and any nel losses incurred by all agency in carrying out. its functions under sections 302 and 303 when the hend of the agency delermines that such net. losses have occurred; and (2) the current market value of the inventory of innterials procurod under section 303 ns of the first day of each fiscul yenr commencing with the first fiscal yenr beginning July 1, 1975. At the close of ench fiscal year there sliall be deposited into the 'Treasury as miscellnneous reccipts, from any amounts appropriated under this section, an amount which the Secretary of the Treasury determines necessary' to provide for clie pryment of any interest accrued and unpaid under this subsection. The rate of such interest. shall be deternined by the Secretary of the Trensury, taking into considerntion the average market yield during the month preceding each fiscnl year on outstnnding marketable obligations of the United States with one year remaining to mnturity." 7xi.

1' J'ublle Law 93-426. Bept. 30, 1974, 'mec. 3. 88 8tat 1107, odded bubrection (b) of sec.

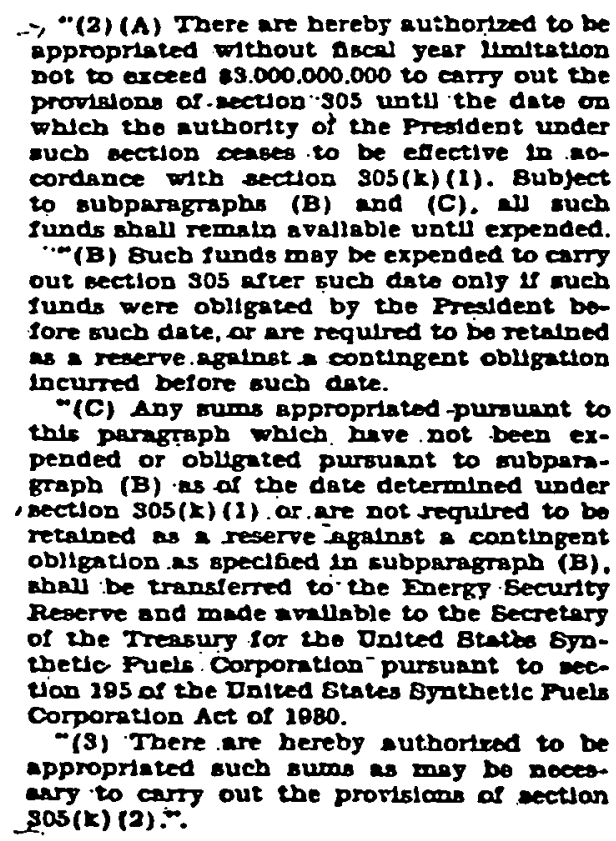




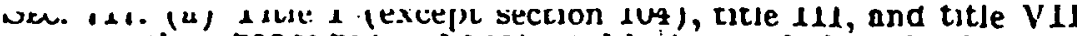
(except sections 708, 714 and 719 ) of this Act, and all authoritp conferred thereunder shall terminate at the close of September 30,1981". Section 714 of this Act, and all nuthority conferred thereunder, shall terminate at the close of July 31, 1953. Section 104, title II, and title VI of this Act, and all authority conferred thereunder, shall terminate at the close of June 30,1953 . Title IV and $V$ of this Act, and all authority conferred thereunder, shall terminate at the close of April 30, 1953.

(b) Notwithstanding the foregoing-

(1) The Congress by concurrent resolution or the President by proclamation may terminate this Act prior to the termination otherwise provided therefor.

(2) The Congress may also provide by concurrent resolution that

1" Autbortir of the President to approve certajn volasitary agreements made permanent. Map 18. 1971 , by 85 Btat 88.

27 Tbe Defepne Pronortjon Act was prated two almnle extepnlons a follows: to Joly 80.

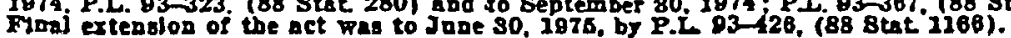

uny section of this Act and all authority conferred thereunder shall terminate prior to the termination otherwise providod therefor.

(3) Any agency created under this Act may be continued in aristence for purposes of liquidstion for not to exceed six months a ftor the termination of the provision authorizing the crention of ach agoncy.

(c) The termination of nay soction of this Lot, or of nny agoney or corporation utilized under this Act, shall not affect the dirburwoment of funds under, or the carrying out of, any contract, guerantee, commitment or other obligation entered into pursuant to this A it prior to the date of such termination, or the tating of any action necessary to preserve or protect the interests of the United States in any amounts advanced or paid out in carrying on operations under this Act, or the taking of any action (including the making of new guarantees) deemed by a gusrantoeing agency to be necessary to accomplish the orderly liquidation, adjustment, or ettlement of any loans guaranteed under this Act, including. actions deemed necessary to avoid undue hardship to borrowers in reconverting to normal civilian production; and all of the authority granted to the President, guaranteeing agencies, and fiscal agents, under section 301 of this Act shall be applicable to actions taken pursuant to the authority contained in this subsection.

Notwithstanding any other provision of this Act the termination of title VI or any section thereof shall not bo construed as atfecting any obligation, condition, liability, or restriction arising out of any arreement heretofore entered into pursuant to, or under the authority of, section 602 or section 605 of this Act, or any istiancs thereunder; by any person or corporation and the Federa Government or any agency thereof relating to the provision of housing for defense wortcrs or military personnel in an area designated $\Sigma$ a critical defense housing area pursuant to law.

(d) No action for the recovery of any cooperative payment made to a cooperative association by \& Market Administrator nnder an invalid provision of a milk marketing order issued by the Secretary of Agriculture pursunt to the Apricultural Marketing Agreement Act of 1937 shall be maintzined unless such action is brought by producers specifically named as party plaintills to recover their respective share of such payments within ninety days after the date of anactment of the Defense Production Act Amendments of 1952 with respect to any cause of action heretoforo accined and not otherwise barred, or within ninety days after accranl with respect to future payments, and unless each claimant shall allego and provo (1) that he objected at the hearing to the provisions of the order nnder which such payments were made and (2) that ho either refused to accept payments computed with such deduction or accepted them under protest to either the Secretary or the Administrator. The district courts of the United States shall havo exclusive oripinal jurisdiction of all such actions regardless of the amont in iolved. This subsection shall not apply to funds held in escrow pursuant to court order. Notwithstanding any other provision of this Act; no termination date ahail be applicable to this subsection. 


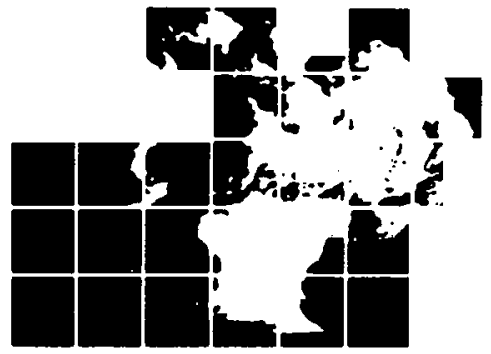

\section{References}

1. The Effects of Nuclear War, Office of Technology Assessment, Congress of the United States, Library of Congress Card Number 79-600.080, U.S. Government Printing Office, Washington, D. C. 20402, 1979.

2. Effects of Nuclear Weapons, Glasstone and Dolan, eds., U.S. Department of Defense and Department of Energy, Washington, D.C., 1977.

3. Review of Nuclear Wcapons Effcct3, H. L. Brode, Ann. Rev. Nuclear Science, Volume 18, p. 153, 1968.

4. Effects of Electromagnetic Pulse on a Power System, Oak Ridge National Laboratory Repurt ORNL 40J6, Déc. 1972.

5. Power System EMP Protection Final Report, Oak Ridge National Laboratory Report ORNL 4958, March 1975.

6. Effects of Nuclear Electromagnetic Pulse (EMP) on Synchronous Stability of the Electric Power System, Oak Ridge National Laboratory, ORNL 4919, Nov. 1975 .

7. A Program to Counter the Effects of Nuclear Electromagnetic Pulse in Commercial Power Systems, Oak Ridge National Laboratory, ORNL-TM-3552, Part 1 .

8. Feasibility of Isolating Vulnerable Equipment of the Electric Power System from Sources of EMP, Final Report, by E. K. Stanek, for the Defense Civil Preparedness Agency (DOD), DCPA 01-76-C-0290. March, 1978.

9. Prototype Plans for Production and Maintenance of Electric Power in Crisis Relocation, Final Report, by D. 0 . Daniel and J. E. Minor for the Defense Civi1 Preparedness Agency (DOD), DCPA 01-74-C-0336. August, 1975. 


\section{Addendum}

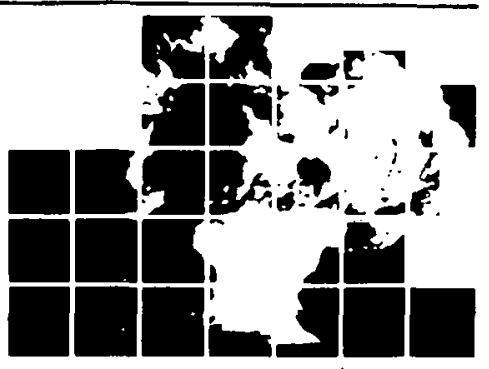

\section{State \\ Plan (s)}

These plans are issued separately by each individual state Civil Defense office. 